VANESSA DE LIMA FERREIRA

\title{
A ESTRATÉGIA NA RELAÇÃO COM OS FORNECEDORES NA INDÚSTRIA AERONÁUTICA BRASILEIRA: \\ O Caso da Embraer
}


VANESSA DE LIMA FERREIRA

\section{A ESTRATÉGIA NA RELAÇÃO COM OS FORNECEDORES NA INDÚSTRIA AERONÁUTICA BRASILEIRA: O Caso da Embraer}

Dissertação apresentada à Escola

Politécnica da Universidade de São Paulo para obtenção do título de Mestre em Engenharia da Produção.

São Paulo - SP 2010 
VANESSA DE LIMA FERREIRA

\section{A ESTRATÉGIA NA RELAÇÃO COM OS FORNECEDORES NA INDÚSTRIA AERONÁUTICA BRASILEIRA: O Caso da Embraer}

Dissertação apresentada à Escola

Politécnica da Universidade de São Paulo para obtenção do título de Mestre em Engenharia da Produção.

Área de Concentração:

Engenharia da Produção

Orientador: Prof. Dr. Mario Sergio Salerno

São Paulo - SP

2010 


\section{FICHA CATALOGRÁFICA}

\section{Ferreira, Vanessa de Lima}

A estratégia na relação com os fornecedores na indústria aeronáutica brasileira: o caso da Embraer / V.L. Ferreira. -- São Paulo, 2010.

$118 \mathrm{p}$.

Dissertação (Mestrado) - Escola Politécnica da Universidade de São Paulo. Departamento de Engenharia de Produção.

1. Alianças estratégicas 2. Aeronáutica 3. Indústria de alta tecnologia I. Universidade de São Paulo. Escola Politécnica. Departamento de Engenharia de Produção II. t. 


\section{AGRADECIMENTOS}

Gostaria de agradecer primeiramente a Deus que me deu o dom da vida e me permitiu experimentar os desafios que ela apresenta, como a execução deste trabalho, e a todos os santos e anjos do Senhor que sopraram sabedoria nos momentos de dúvida.

Agradeço também aos meus pais, meus heróis, que me ensinaram os primeiros passos, me ensinaram a decifrar as primeiras letras, e serviram de exemplo para perseguir a vitória.

Agradeço à minha irmã, ao meu cunhado e ao meu querido sobrinho, e também aos queridos amigos que souberam compreender minha ausência em vários momentos. Também gostaria de agradecer aos colegas de trabalho da Embraer, que me apoiaram nos momentos de ausência em que estava nas aulas e junto comigo torceram e sofreram. Agradeço em especial ao Paulo Lourenção, que me incentivou e abriu diversas portas, e me fez persistir.

Agradeço a todas as pessoas que entrevistei, as quais me dispensaram seu tempo precioso e comigo compartilharam seus conhecimentos riquíssimos sem os quais não poderia ter seguido em frente.

E por fim, mas não menos importante, meu agradecimento em especial ao meu orientador Professor Mário Sérgio Salerno, que foi um verdadeiro mestre, que acreditou em mim e me fez acreditar no potencial que eu mesma desconhecia. $\mathrm{O}$ respeito, a amizade e admiração pelo professor Mário serão eternos. 
Loucura? Sonho? Tudo é loucura ou sonho no começo. Nada que o homem fez no mundo teve início de outra maneira - mas já tantos sonhos se realizaram que não temos o direito de duvidar de nenhum.

(Monteiro Lobato) 


\section{RESUMO}

Este trabalho aborda a estratégia na relação com os fornecedores em empresas de alta tecnologia e produtos complexos. Para tanto, foi tomado o caso da fabricação de aeronaves produzidas pela Embraer, que se destacou pela sua estratégia de parceria com seus fornecedores, principalmente na linha dos produtos das Famílias ERJ 145 e E-Jets. No entanto, na sua última linha de produtos, o que se percebe é uma estratégia diferenciada no seu modo de se relacionar com seus fornecedores, o que levou à questão da pesquisa. O presente trabalho discute as opções de relacionamento com fornecedores, do simples fornecimento ao compartilhamento de investimentos e riscos, e as racionalidades subjacentes. As técnicas utilizadas para elaborar o trabalho foram observação direta e pesquisa em dados secundários, revistas especializadas, web sites vinculados à indústria aeronáutica e associações, artigos acadêmicos e documentos da empresa. Além disso, foram conduzidas entrevistas semi-estruturadas, com empregados e ex-empregados da empresa, inclusive diretores. Os resultados mostram que, apesar de as grandes empresas como Boeing e Airbus terem adotado o modelo de parceria de risco desenvolvido pela empresa em estudo, esta hoje adota um modelo híbrido, com foco em lições anteriormente aprendidas na relação com fornecedores.

Palavras-chave: Relacionamento fabricante-fornecedor. Parceria. Indústria aeronáutica. 


\begin{abstract}
This paper discusses the strategy for relationship with the suppliers at high-tech and complex product companies. Therefore, the case studied was the manufacture of aircraft produced by Embraer and its unique strategy of partnering with suppliers, mainly when dealing the products of the ERJ145 and E-Jets families. In the company's latest line of products a particular strategy is observed in terms of relationship with suppliers, which led to our research question. This paper discusses the options of supplier relationships, from simple supply to shared investments and risks, and the rationales that underly them. The techniques used in this study were direct observation and research on secondary data, journals, websites linked to the aircraft industry and associations, academic papers, and the company's documents. In addition, semi-structured interviews were conducted with both current and former employees. The results show that despite the fact that large companies like Boeing and Airbus use the partnership model of risk adopted by the company under study, Embraer is currently adopting a hybrid model focusing on lessons learned earlier in its supply chain.
\end{abstract}

Keywords: Buyer-Supplier Relationship. Partnership. Aeronautic industry. 
LISTA DE ILUSTRAÇÕES

FIGURA 1 - PRINCIPAIS PRESSUPOSTOS DA GESTÃO DA CADEIA DE SUPRIMENTOS PARA VEÍCULOS. .22

FIGURA 2 - ANÁLISE ESTRATÉGICA DA DECISÃO DE FAZER OU

COMPRAR. .24

FIGURA 3 - PROCESSO DE DESENVOLVIMENTO DE PRODUTO.......................25

FIGURA 4 - GESTÃO DE TECNOLOGIA VERSUS GESTÃO DE NEGÓCIOS ......25

FIGURA 5 - ROADMAP TECNOLÓGICO …....................................................26

FIGURA 6 - INTEGRAÇÃO VERTICAL VERSUS ORGANIZAÇÃO MODULAR.....32

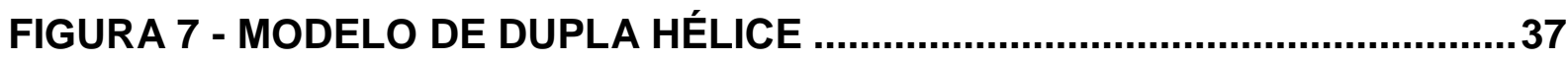

FIGURA 8 - MODELO DE COLABORAÇÃO ….................................................40

FIGURA 9 - ESTRUTURA DE FORNECIMENTO DA CADEIA DE

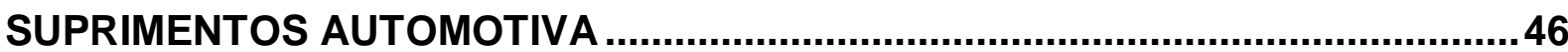

FIGURA 10 - UNIDADES E ESCRITÓRIOS DA EMBRAER NO MUNDO ...............54

FIGURA 11 - TOTAL DE AERONAVES ENTREGUES NOS ÚLTIMOS ANOS

PELA EMBRAER. 58

FIGURA 12 - PRODUTOS DA AVIAÇÃO EXECUTIVA DA EMBRAER E SEUS

CONCORRENTES 60

FIGURA 13 - HISTÓRICO E PREVISÃO DE ENTREGA DE JATOS

EXECUTIVOS 61

FIGURA 14 - HISTÓRICO DE ENTREGAS DE JATOS EXECUTIVOS 62

FIGURA 15 - PERCENTUAL DE PARTICIPAÇÃO DA EMBRAER NA

AVIAÇÃO EXECUTIVA 62

FIGURA 16 - ESTRUTURA DA CADEIA DE SUPRIMENTOS AERONÁUTICA .....64 FIGURA 17 - FAMÍLIA 145 COM 4 PARCEIROS DE RISCO E 350

FORNECEDORES 67

FIGURA 18 - FAMÍLIA E-JETS COM 16 PARCEIROS DE RISCO E 22

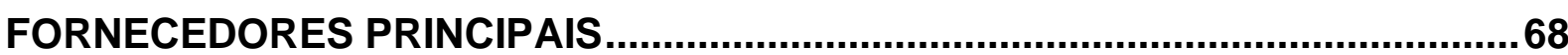

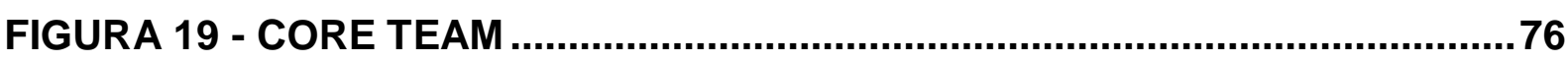

FIGURA 20 - DESENVOLVIMENTO INTEGRADO DO PRODUTO ..........................77

FIGURA 21 - MOCK-UP DIGITAL …..............................................................

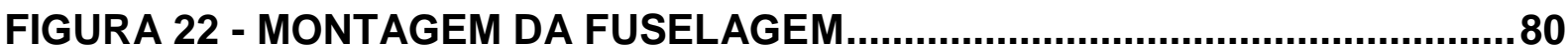




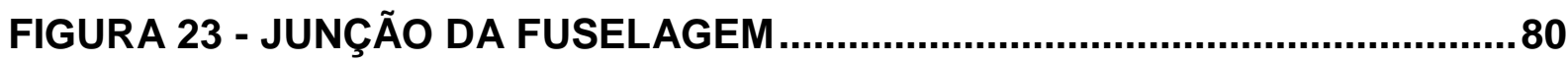

FIGURA 24 - MONTAGEM DOS COMPONENTES............................................ 81

FIGURA 25 - EVOLUÇÃO DA CADEIA PRODUTIVA NO MUNDO .........................89 


\section{LISTA DE QUADROS}

QUADRO 1 - MODELOS CLÁSSICOS DE FAZER VERSUS COMPRAR 23

QUADRO 2 - VANTAGENS ESTRATÉGICAS ATRAVÉS DA INOVAÇÃO 27 QUADRO 3 - PARTICIPAÇÃO BRASILEIRA NOS PROJETOS DAS MONTADORAS 28

QUADRO 4 - ORGANIZAÇÃO MODULAR VERSUS ORGANIZAÇÃO

INTEGRADA VERTICALMENTE. 33

QUADRO 5 - ORGANIZAÇÃO MODULAR VERSUS ORGANIZAÇÃO VERTICAL SEGUNDO LANGLOIS .34

QUADRO 6 - FATORES QUE INFLUEM NA CAPACITAÇÃO DA EMPRESA .......36

QUADRO 7 - DEFINIÇÕES DE ALIANÇA ESTRATÉGICA .................................41

QUADRO 8 - RESUMO REFERENCIAL ….....................................................47

QUADRO 9 - PERFIL DOS ENTREVISTADOS NA PRIMEIRA ETAPA …..............50

QUADRO 10 - PERFIL DOS ENTREVISTADOS NA SEGUNDA ETAPA …...........51

QUADRO 11 - PRINCIPAIS ENFOQUES METODOLÓGICOS DESTA

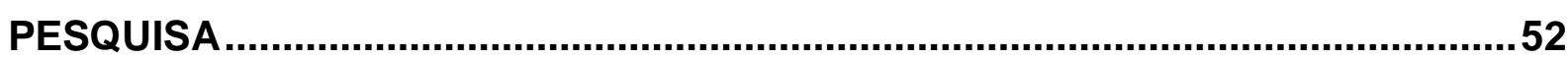

QUADRO 12 - DADOS SOBRE A EMBRAER. ............................................54

QUADRO 13 - PRINCIPAIS EVENTOS DA HISTÓRIA DA EMBRAER ..................57

QUADRO 14 - PRINCIPAIS PRODUTOS AERONÁUTICOS DA AVIAÇÃO

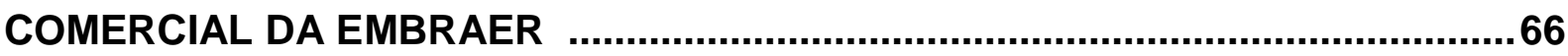

QUADRO 15 - PRINCIPAIS PRODUTOS AERONÁUTICOS DA AVIAÇÃO

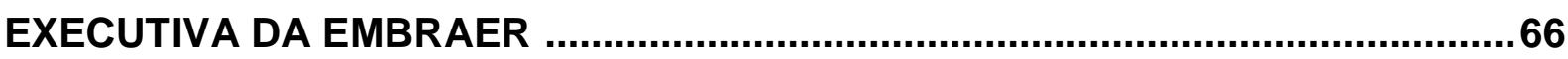

QUADRO 16 - PRODUTOS DA AVIAÇÃO COMERCIAL DA EMBRAER E SEUS PRINCIPAIS CONCORRENTES..........................................................69

QUADRO 17 - PRIMEIRAS AERONAVES DA ÁREA DE DEFESA. ......................73

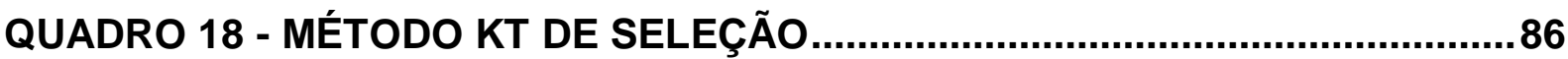

QUADRO 19 - EVOLUÇÃO DOS MODELOS …................................................. 


\section{SUMÁRIO}

1 INTRODUÇÃO

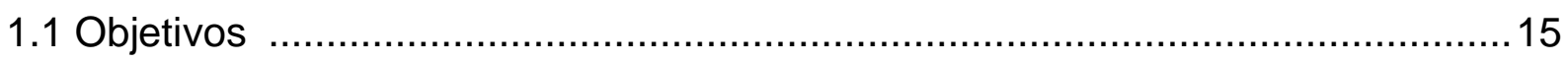

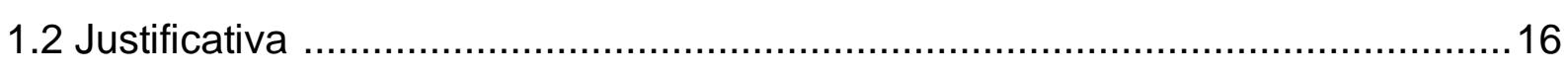

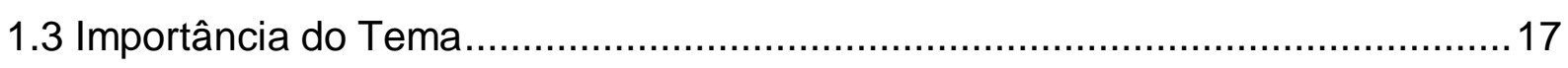

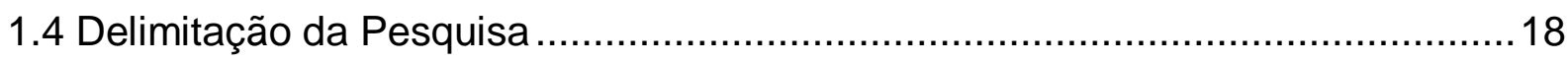

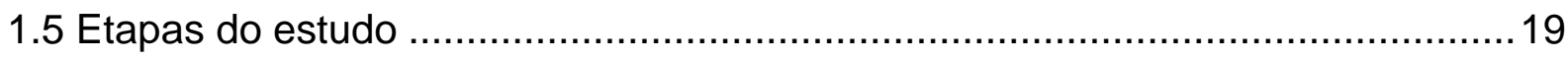

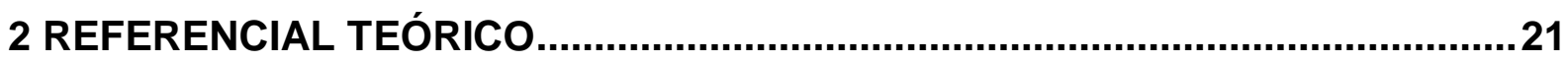

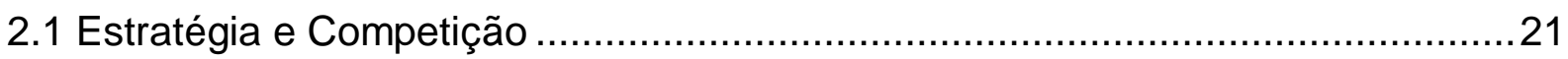

2.2 Estratégias Frente à Gestão de Desenvolvimento de Produto: Tecnologia, Inovação e Arquitetura do Produto ................................................................24

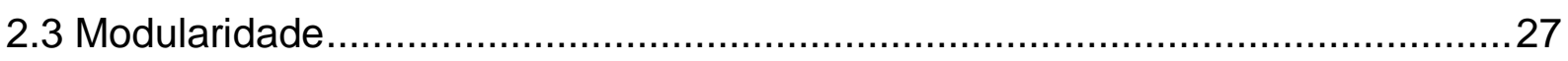

2.3.1 Formas Organizacionais: Integração Vertical x Desintegração ....................... 31

2.4 Estratégias Frente à Gestão de Cadeia de Fornecimento..................................38

2.4.1 Gestão de Parcerias: Alianças Estratégicas...................................................... 39

2.5 Problemas na Seleção de Fornecedores .................................................... 42

2.6 Critérios para Seleção de Fornecedores nas Montadoras ………...................... 43

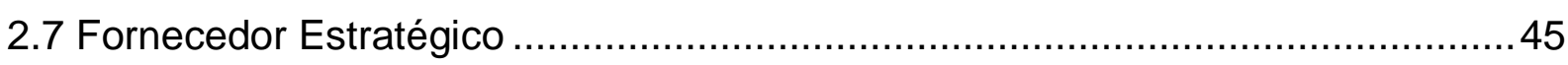

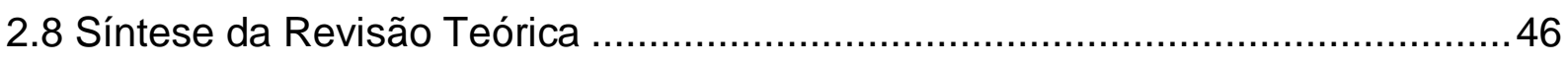

3 METODOLOGIA

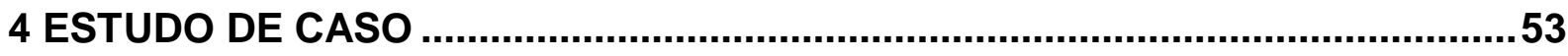

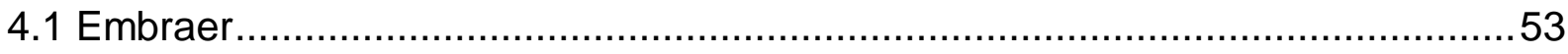

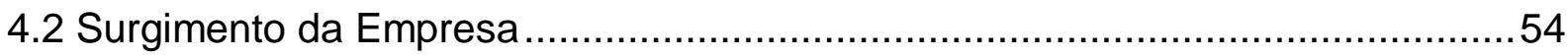

4.2.1 Do Bandeirante ao Nascimento da Embraer ..............................................55

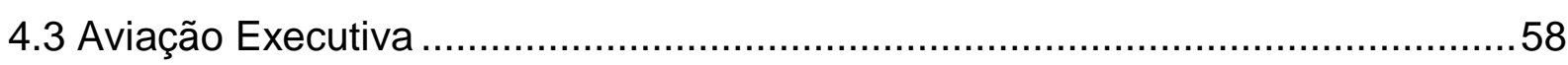

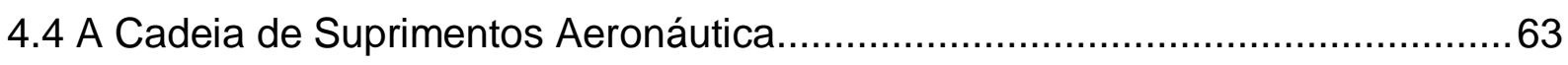

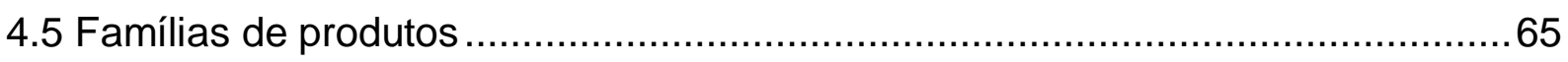

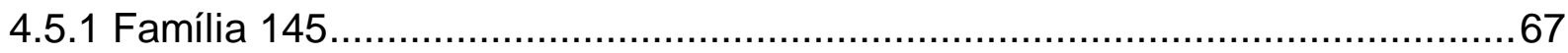

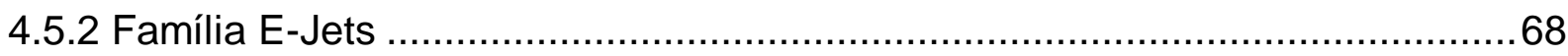

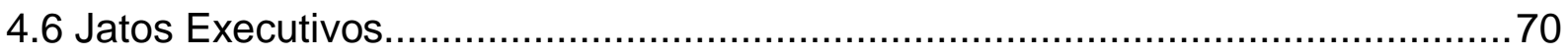

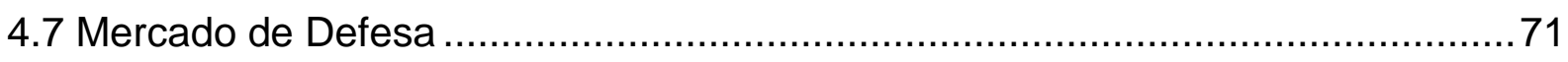




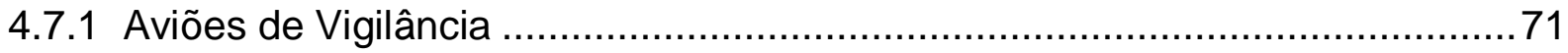

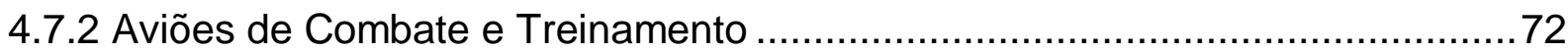

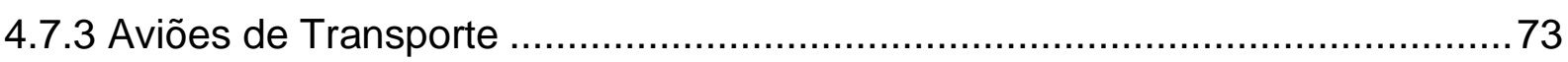

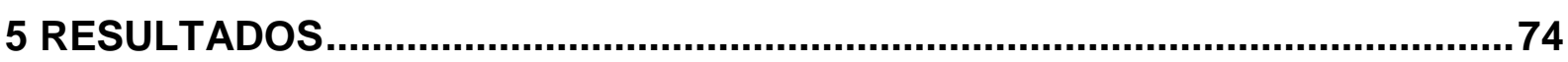

5.1 Identificação das Práticas de Desenvolvimento de Produto: Decisões de

Make or Buy e Definição de Parceiros e Fornecedores. ...................................74

5.1.1 Da Elaboração do Projeto à Fabricação da Aeronave......................................77

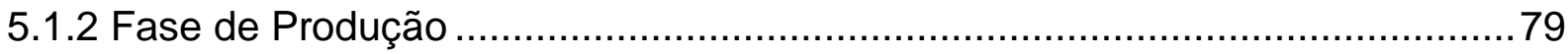

5.2 Identificação de Práticas de Alianças Estratégicas: Definições de Parcerias e

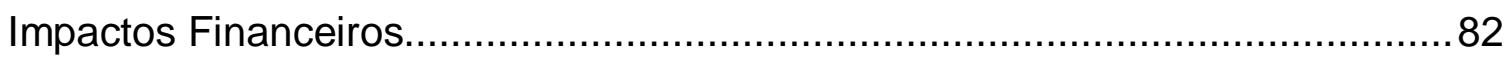

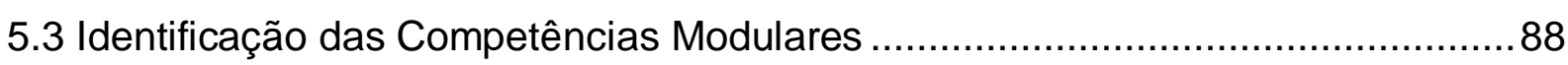

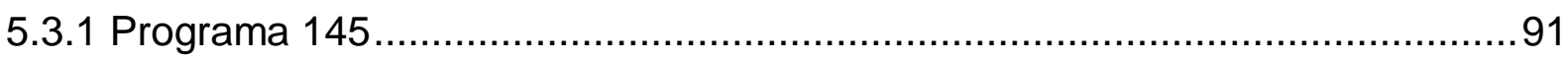

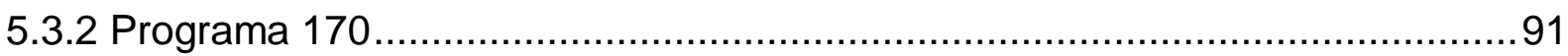

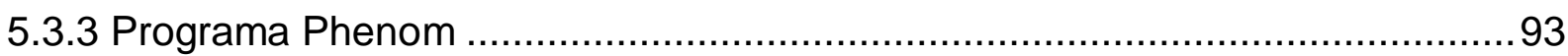

5.3.4 Programa Jatos Médios (Legacy 450/500) …….........................................94

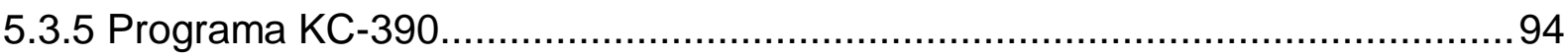

5.4 A evolução dos programas sob o aspecto das implicações apontadas nas

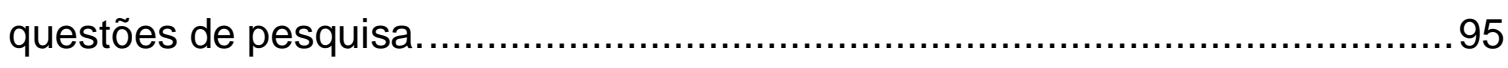

6 CONCLUSÕES

7 SUGESTÕES DE TRABALHOS FUTUROS …................................................102

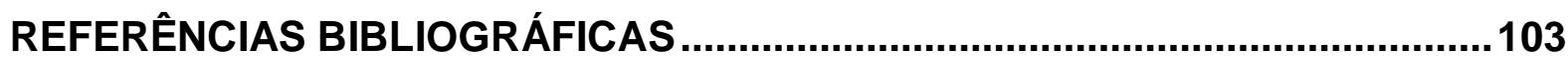

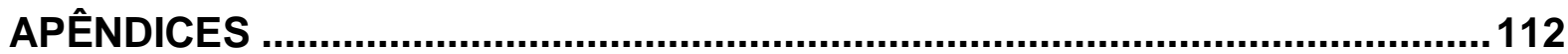

APÊNDICE A - Entrevistas - Primeira Parte .....................................................112

APÊNDICE B - Entrevistas - Segunda Parte .................................................113

ANEXO A - Fornecedores de Primeiro Nível do Programa ERJ 135/140/145 ........115

ANEXO B - Fornecedores de Primeiro Nível do Programa ERJ 170/190 …..........117

ANEXO C - Empresas locais subcontratada e seus parceiros de riscos ...............119 


\section{INTRODUÇÃO}

O tema desta dissertação é a estratégia na relação com os fornecedores em empresas de alta tecnologia e produtos complexos.

Após um período de forte terceirização, muitas empresas voltaram a produzir internamente conjuntos de peças, itens, subconjuntos ou módulos. A presente dissertação visa a discutir o porquê dessa decisão, qual lógica a preside. Para tanto, foi tomado o caso da fabricação de aeronaves produzidas pela Embraer. A empresa se destacou pela sua estratégia de parcerias com seus fornecedores, particularmente na linha de produtos das Famílias 145 e E-Jets, servindo de modelo para que outras empresas gigantes do setor, como Boeing e Airbus, adotassem o mesmo caminho, terceirizando parte significativa de sua produção dentro de um modelo de parceria de riscos. Acontece que, na sua última linha de produtos (aviação executiva), a empresa adotou uma estratégia diferenciada no seu modo de relacionamento com seus fornecedores, o que levou à questão da pesquisa.

Nos últimos 20 anos os fabricantes reconheceram a contribuição valiosa dos fornecedores para o desenvolvimento de novos produtos (CLARK E FUJIMOTO, 1991), e passaram a convidá-los para projetá-los conjuntamente. Esse cenário mostra que os fabricantes têm de coordenar as várias atividades de desenvolvimento de produto com diversos fornecedores. Se houver falha na coordenação dessas atividades as consequências poderão ser, entre outras: atraso de projeto, aumento dos custos de desenvolvimento e dificuldade de integração entre os diversos componentes provenientes de diferentes fornecedores.

A Boeing está sofrendo atrasos no seu novo projeto (787 Dreamliner), ocasionados pelo desafio da sua cadeia de suprimentos e por diversas dificuldades de integração de todos os componentes (HONG; PEARSON; CARR, 2009).

Alguns fornecedores podem receber autonomia com relação ao projeto de certos módulos e até mesmo ter que assegurar a funcionalidade desses com outros, trabalhando diretamente com diversos fornecedores. O fabricante precisa coordenar o trabalho com diversos fornecedores cujas atividades são inter-relacionadas. Neste cenário, o modelo de produção em rede modular vem crescendo e com ele o compartilhamento das atividades de desenvolvimento de produto e produção com os 
diversos integrantes da cadeia de suprimentos. No entanto, a modularidade não deve ser entendida somente como estratégia de projeto (projeto modular), de produção ou de uso, como definem muitos autores como Baldwin e Clark (1997), mas sim como uma nova forma de relacionamento entre montadoras e fornecedores que remodela o limite da indústria, redefinindo o negócio e os riscos a ele relacionados (SALERNO, 2001).

Esse processo de transferência e compartilhamento de atividade com os fornecedores ressalta a importância das parcerias. Humphries e Wilding (2001) entendem que parceria é uma abordagem ampla para a gestão da cadeia de suprimentos, envolvendo tecnologia, processo e informação, baseada em confiança e comprometimento no longo prazo, tendo como meta assegurar retornos financeiros para os membros da cadeia.

Dado esse contexto, o presente estudo abordará os temas acima expostos (desenvolvimento de produto, decisões de fazer ou comprar e relacionamento com fornecedores) comparando a teoria com os resultados constatados no estudo de caso realizado na maior fabricante de aviões do país, a Embraer.

\subsection{Objetivos}

Investigar os fatores que levaram à adoção de estratégias de parcerias de risco em um caso, e ao seu abrandamento em outro. Analisar a estratégia na relação com os fornecedores para os principais produtos, incluindo a decisão de produzir ou comprar.

Para investigar a estratégia com os fornecedores, faz-se necessário estabelecer os seguintes objetivos secundários:

- Levantar a evolução dos projetos no que se refere à forma como a fabricante coordena as atividades de desenvolvimento do produto com os diversos fornecedores, até chegar à última linha de produtos em produção (segmento da aviação executiva).

- Identificar os principais critérios utilizados na seleção dos fornecedores em cada linha de produtos. 
- Verificar quais as estratégias de fornecimento modular que a empresa possui em cada caso, uma vez que, ao utilizar a modularidade, o número de fornecedores diretos diminui e estes podem passar a ser responsáveis pelos fornecedores de outros níveis (2ำ nível, $3^{\circ}$ nível etc.), ao menos potencialmente.

\subsection{Justificativa}

Segundo Montoro e Migon (2009), a importância do setor aeronáutico é realçada pelo seu grande potencial de crescimento face à expansão da economia, pelo relevante conteúdo tecnológico, pelo alto valor agregado e pela expressiva contribuição para o saldo da balança comercial brasileira. A indústria aeronáutica é um dos melhores exemplos de projetos estratégicos bem sucedidos, resultando em uma atividade industrial de alto conteúdo tecnológico e valor agregado, capaz de gerar exportações e saldos comerciais. A Embraer se tornou uma das maiores fabricantes de aeronaves civis do mundo, levando o Brasil, país das commodities como ressaltam Montoro e Migon (2009) - a ter aeronaves como um dos principais itens de sua pauta de exportações, com expressiva geração de emprego e saldos comerciais para o país. O presente trabalho estuda a relação de parcerias comerciais da Embraer com seus fornecedores, a qual foi responsável, entre outros fatores, pelo sucesso da empresa. Algumas empresas se especializaram em determinado tipo de atividade e adquiriram maior competitividade e, neste caso, agregá-las ao projeto aumenta a competitividade, comenta o ex-vice-presidente de Planejamento Estratégico e Desenvolvimento Tecnológico da Embraer, Satoshi Yokota apud Barbosa (2008).

No modelo 787, a Boeing levou esse modelo de negócio para um novo patamar, com a terceirização de $90 \%$ da produção, sendo $70 \%$ do conteúdo produzido fora dos Estados Unidos. Na Embraer, $60 \%$ são produzidos por terceiros (BARBOSA, 2008). A fabricante Airbus se desfez de subsidiárias espalhadas pela Europa e transferiu sua produção para países mais competitivos, a fim de reduzir seus custos. A meta da empresa é que até $2013,70 \%$ do jato Airbus A350, por 
exemplo, venha de fora do continente (BARBOSA, 2008).

Enquanto as gigantes do setor, Boeing e Airbus, se adaptam ao modelo de parcerias anteriormente testado pela Embraer, esta se mostra utilizando alternativas a serem discutidas no presente trabalho, como a adoção de fornecedores principais, fornecimento por módulos e gerenciamento da maioria dos fornecedores de sua cadeia.

\subsection{Importância do Tema}

Segundo Bertaglia (2006), o processo de seleção de fornecedor não é simples. A complexidade aumenta em função das características do item ou serviço a ser adquirido, pois as exigências podem ser maiores ou menores como, por exemplo, no caso da aviação executiva, cujas características do produto podem variar muito em função do cliente.

De acordo com Martins (2005), nos últimos anos a estratégia na seleção de fornecedores vem se tornando cada vez mais importante para as empresas devido a vários fatores, entre eles: o aumento no valor dos itens comprados em relação ao total da receita das empresas, a aquisição de produtos de outros países viabilizados pela globalização a preços competitivos, e a crescente velocidade de mudança de tecnologia, acompanhada por uma redução do ciclo de vida dos produtos.

Segundo Slack et al. (2002), a definição de quantos e quais são fornecedores com que a empresa trabalhará faz parte de sua estratégia de compras e influencia diretamente os resultados da empresa. Para ver o grau de importância dessa definição de fornecedores, em 2006 a Embraer deixou de entregar várias aeronaves vendidas dentro do prazo estipulado em contrato devido ao atraso de seus fornecedores, gerando multas contratuais e redução de receita no ano (EMBRAER, 2008b).

Barbosa (2008) relata que, inicialmente, o modelo de parcerias com adoção de parceiros de risco na Boeing gerou uma economia de 8 bilhões de dólares em 2006. Entretanto, os atrasos atribuídos a problemas enfrentados por fornecedores terceirizados consumiram algo como 3 bilhões de dólares em multas pagas a 
clientes, assim como aconteceu com a Embraer, conforme descrito anteriormente. Diante de uma série de problemas, a Boeing reviu seus contratos e exigiu que os maiores fornecedores construíssem fábricas ao lado da sua linha de montagem. A empresa em estudo também o fez em muitos casos para evitar ter de transportar peças gigantescas pelo mundo.

Para a seleção de fornecedores, os critérios têm deixado de ser meramente aqueles básicos, ou seja, o preço pelo qual o fornecedor oferecia o produto, sua qualidade - que deveria atender à especificação mínima requerida pela empresa - e a velocidade de entrega do produto pelo fornecedor.

Entre os novos critérios que passaram a ser adotados encontram-se a capacidade financeira (pois reduz o risco de descontinuidade de fornecimento e permite a atualização tecnológica); a qualificação do processo de produção avaliado pela engenharia de montagem e departamento de qualidade; a capacidade da engenharia de proporcionar tecnologias compatíveis ao mercado e, finalmente, a capacidade de desenvolvimento de produto e histórico de fornecimento, conforme afirmam Salerno et al (2009), pesquisando o setor automotivo.

\subsection{Delimitação da Pesquisa}

O trabalho foca na análise da estratégia em relação aos fornecedores das seguintes famílias de produtos:

a) Família 145, composta por jatos pressurizados para transporte regional, tendo como principais características alto desempenho, baixos custos de operação, equipado com eficientes motores turbofan de baixo nível de ruído e de consumo de combustível, com capacidade de 50 lugares, disponível nas versões Enhanced Range (ER), Long Range (LR) e Extra Long Range (XR);

b) Família E-Jets, formada por jatos com características semelhantes às da família anterior, mas com capacidade entre 70 e 90 passageiros, ampliada posteriormente para 110 passageiros, e;

c) Família Phenom, da aviação executiva, como o Phenom 100 e 300, jatos 
executivos pertencentes à categoria entry level com capacidade entre oito e dez pessoas, respectivamente, e projetada para decolar em distâncias curtas, sendo que o Phenom 300 tem alcance $50 \%$ superior ao Phenom 100.

A Embraer está, neste primeiro semestre de 2010, em projeto inicial de família de Jatos Médios da aviação executiva (Legacy450 e Legacy500) e da Família de Cargueiro (KC-390) da aviação militar; essas famílias, portanto, foram utilizadas como casos auxiliares, para verificação das lógicas percebidas nos casos centrais (Famílias 145, E-Jets e Phenom).

\subsection{Etapas do estudo}

A primeira etapa desta pesquisa consiste na revisão literária descrita no Capítulo 2, em que aborda os assuntos diversos subdivididos em várias seções. As primeiras (2.1 e 2.2) abordam o assunto de estratégias com foco na competência da empresa e no processo de desenvolvimento de produto, este vinculado com tecnologia e inovação, e complementa o tema com a definição da arquitetura do produto (modular/integral) como parte dessa atividade. A seção seguinte (2.3) aborda a modularidade estabelecendo as implicações dessa estratégia no modelo de gestão. A próxima seção (2.4) aborda a estratégia frente à cadeia de fornecimento, dando ênfase aos tipos de relacionamento, dentre eles as parcerias estratégicas. As seções 2.5, 2.6 e 2.7 abordam critérios da seleção de fornecedores. Encerrando o capítulo, a seção 2.8 traz um resumo da literatura revista com a finalidade de definir as proposições para alcançar os objetivos estabelecidos neste estudo.

O Capítulo 3 se refere aos métodos e técnicas adotados para a condução do trabalho, traz o critério para a escolha do caso, os procedimentos de coleta e análise dos dados, e as limitações da pesquisa.

O Capítulo 4 apresenta a empresa em estudo, trazendo seu histórico e uma breve explicação sobre seus produtos. Além disso, o capítulo procura descrever a cadeia de suprimentos aeronáutica para maior compreensão do processo. 
O Capítulo 5 apresenta os resultados dos levantamentos realizados, com ênfase no reconhecimento das práticas de desenvolvimento de produto, nas alianças estratégicas para fornecimento, e as implicações da modularidade na empresa em estudo.

O Capítulo 6 analisa os resultados do estudo frente às questões de pesquisa colocadas no trabalho, como os fatores que levaram à adoção de estratégias de parcerias de risco em um caso e o seu abrandamento em outro, a evolução dos projetos com relação aos fornecedores até a última linha de produtos, os requisitos de seleção dos fornecedores e as estratégias de fornecimento modular. O capítulo apresenta as conclusões quanto aos principais aspectos evidenciados.

Encerrando o trabalho, o Capítulo 7 traz as oportunidades para pesquisas subsequentes. 


\section{REFERENCIAL TEÓRICO}

Esta seção aborda os conceitos relacionados às estratégias de negócios e de produção, focando na decisão de produzir ou comprar (make or buy), nos tipos de relações com fornecedores e nos critérios para sua seleção. São mencionados os tópicos referentes a estratégia e critérios de seleção. Uma vez que a aeronave é constituída por módulos ${ }^{1}$ ou subconjuntos (ou assim pode ser descrito), e que a parceria com os fornecedores se faz, principalmente, a partir de módulos, faz-se necessária uma breve discussão sobre modularidade.

\subsection{Estratégia e Competição}

A competitividade tem sido uma das grandes questões empresariais brasileiras. As transformações na economia do país ocasionadas pela abertura de mercado e pela estabilidade monetária fizeram com que as estratégias empresariais se voltassem cada vez mais para a longevidade da empresa, explica Silva (2001).

Fleury e Fleury (2003) consideram que, no processo de reestruturação das empresas e de seus negócios, a competitividade exige eficiência coletiva e as empresas devem focar cada vez mais nas suas competências (core competence).

Prahalad e Hamel (1990) comparam as empresas com uma grande árvore, onde o tronco e os galhos são os produtos essenciais, os galhos menores são as unidades de negócio, e as folhas, flores e frutos, os produtos. O sistema de raiz é a competência essencial que prove a nutrição, sustentação e estabilidade para a empresa.

"Você pode deixar de perceber a energia dos concorrentes se somente olhar para seus produtos finais, da mesma forma que deixará de perceber a da árvore se somente olhar para as folhas" (PRAHALAD; HAMEL, 1990, p. 297).

A competitividade no setor aeronáutico envolve diversas características,

Não é nosso objetivo realizar a discussão sobre o conceito de módulo, que aqui será tratado como sinônimo de subconjunto (SALERNO, 2001). 
dentre elas: produto de alta complexidade, grande dinâmica tecnológica, longo período de maturação de projetos, alto risco financeiro, necessidade de quantias expressivas de capital de giro, retorno não imediato do capital investido e prazos extensos para pagamento das vendas, conforme explica Miranda, 2007. Além disso, a produção se faz sob encomenda e há grandes prazos para entrega do produto.

Uma das maneiras de as empresas inseridas nesse setor se manterem competitivas é focar na gestão da cadeia de fornecimento (Supply Chain Management - SCM), pois é aí que estão concentrados os maiores custos relacionados ao seu produto final. Segundo Slack et al. (2002), a otimização da cadeia como um todo pode ser atingida se cada empresa, em cada elo da cadeia, buscar eficiência operacional de suas atividades. Os autores Alves Filho et al. (2004) afirmam que um dos principais pressupostos que devem estar associados à gestão da cadeia de suprimentos se resume a uma estrutura enxuta de fornecedores alinhada com planejamento estratégico e com relações de parcerias de longo prazo, conforme ilustrado na Figura 1:

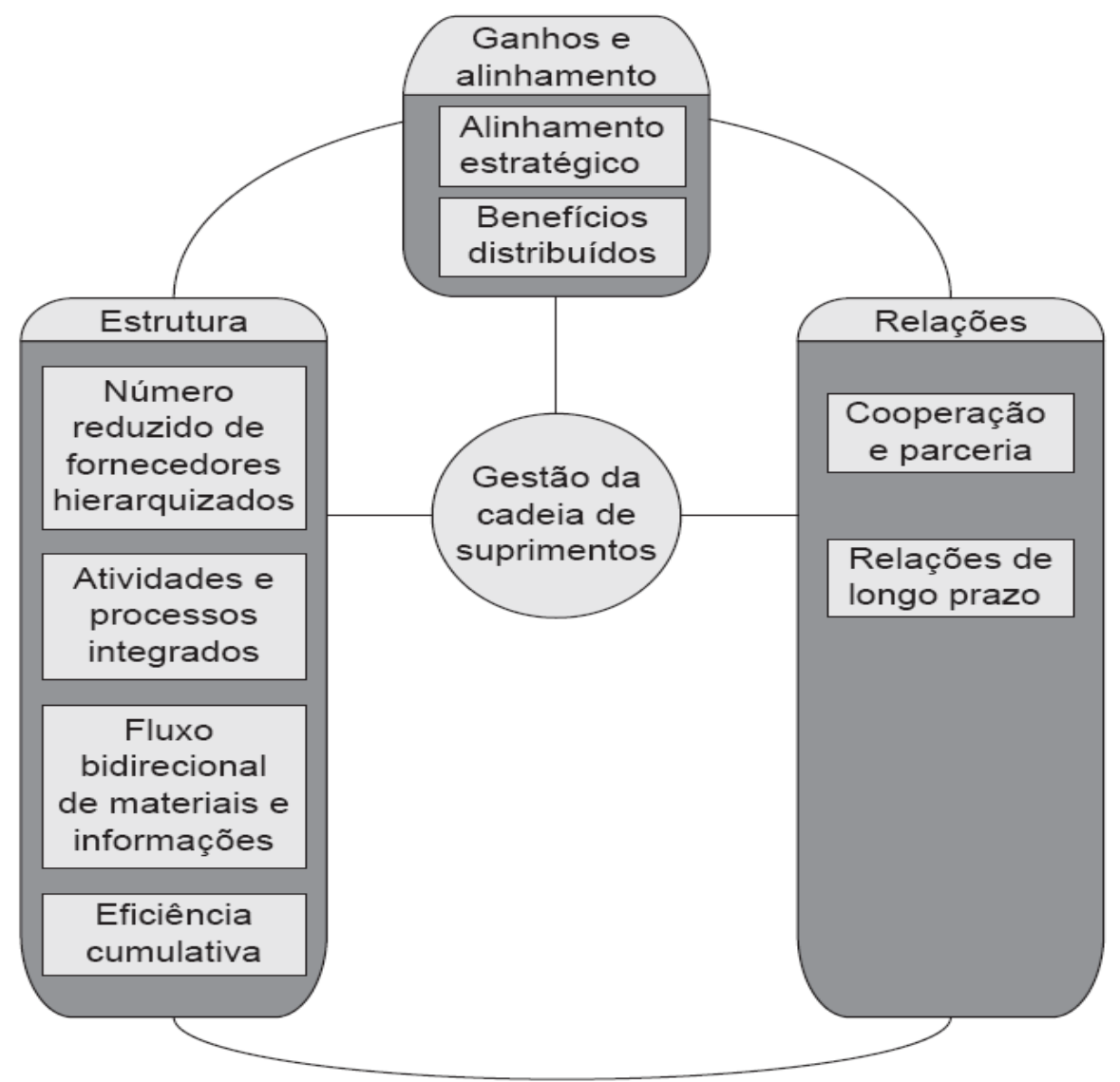

Figura 1 - Principais pressupostos da gestão da cadeia de suprimentos para veículos Fonte: Alves Filho et al. (2004). 
Além disso, as empresas estão inseridas em cenários de mudanças constantes: ora se tem um setor integrado verticalmente, ora este se apresenta desintegrado horizontalmente. Nesse contexto é fundamental o domínio das competências essenciais, o que leva à importante análise em cada projeto novo sobre a decisão de fazer versus comprar. Segundo Gutwald (1995) apud Di Serio e Sampaio (2001), os modelos clássicos de decisão fazer versus comprar podem ser classificados conforme o Quadro 1:

\begin{tabular}{|c|c|c|c|c|}
\hline & $\begin{array}{l}\text { Análise } \\
\text { Econômica }\end{array}$ & $\begin{array}{l}\text { Análise do Custo } \\
\text { de Transação }\end{array}$ & $\begin{array}{l}\text { Análise } \\
\text { Estratégica }\end{array}$ & $\begin{array}{l}\text { Análise } \\
\text { Multidimensional }\end{array}$ \\
\hline Origem & Finanças & Economia & Administração & Transdisciplinar \\
\hline Enfoque & Custo & Transação & Estratégia & Plural \\
\hline \multirow{2}{*}{$\begin{array}{l}\text { Críticas } \\
\text { Específicas }\end{array}$} & $\begin{array}{l}\text { Ignora a } \\
\text { existência de } \\
\text { custos ocultos, } \\
\text { como o custo de } \\
\text { transação }\end{array}$ & $\begin{array}{l}\text { Desconsidera os } \\
\text { ativos intangíveis } \\
\text { e estratégicos nas } \\
\text { equações } \\
\text { econômicas }\end{array}$ & $\begin{array}{l}\text { Não preserva o } \\
\text { conhecimento } \\
\text { de uma } \\
\text { atividade } \\
\text { terceirizada }\end{array}$ & $\begin{array}{l}\text { Os pressupostos } \\
\text { são os mesmos dos } \\
\text { modelos anteriores }\end{array}$ \\
\hline & $\begin{array}{l}\text { Ignora a } \\
\text { existência de } \\
\text { fornecedores } \\
\text { oportunistas }\end{array}$ & $\begin{array}{l}\text { Considera que as } \\
\text { cadeias de } \\
\text { suprimentos são } \\
\text { arquitetadas para } \\
\text { a redução de } \\
\text { custo }\end{array}$ & $\begin{array}{l}\text { Assume que as } \\
\text { competências } \\
\text { essenciais serão } \\
\text { as mesmas } \\
\text { competências } \\
\text { futuras }\end{array}$ & $\begin{array}{l}\text { As críticas são } \\
\text { diluídas, mas } \\
\text { permanecem }\end{array}$ \\
\hline
\end{tabular}

Quadro 1 - Modelos clássicos de fazer versus comprar

Fonte: adaptado de Gutwald (1995) apud Di Serio e Sampaio (2001).

Gutwald (1995) apud Di Serio e Sampaio (2001) complementa dizendo que a maneira mais antiga de abordar essa questão é a análise econômica, que consiste em comparar o custo de fabricação interno de um determinado componente com o custo de aquisição no mercado. A abordagem de Hamel e Prahalad (1994) consiste em focalizar os esforços e investimentos da organização nas competências essenciais, classificadas em dois critérios: importância estratégica e competência relativa no mercado.

A importância estratégica traz a análise das competências da empresa, questionando se a atividade poderá ou não diferenciá-la em relação aos concorrentes, aumentando o valor que é percebido pelo cliente. Já a competência relativa compara a capacidade da empresa com a dos demais concorrentes considerando custos, qualidade e processo, conforme visualizado na Figura 2.

Para acompanhar a estratégia e a competição, as empresas estão, conforme cada caso, adotando uma estratégia global conforme descrito a seguir. 


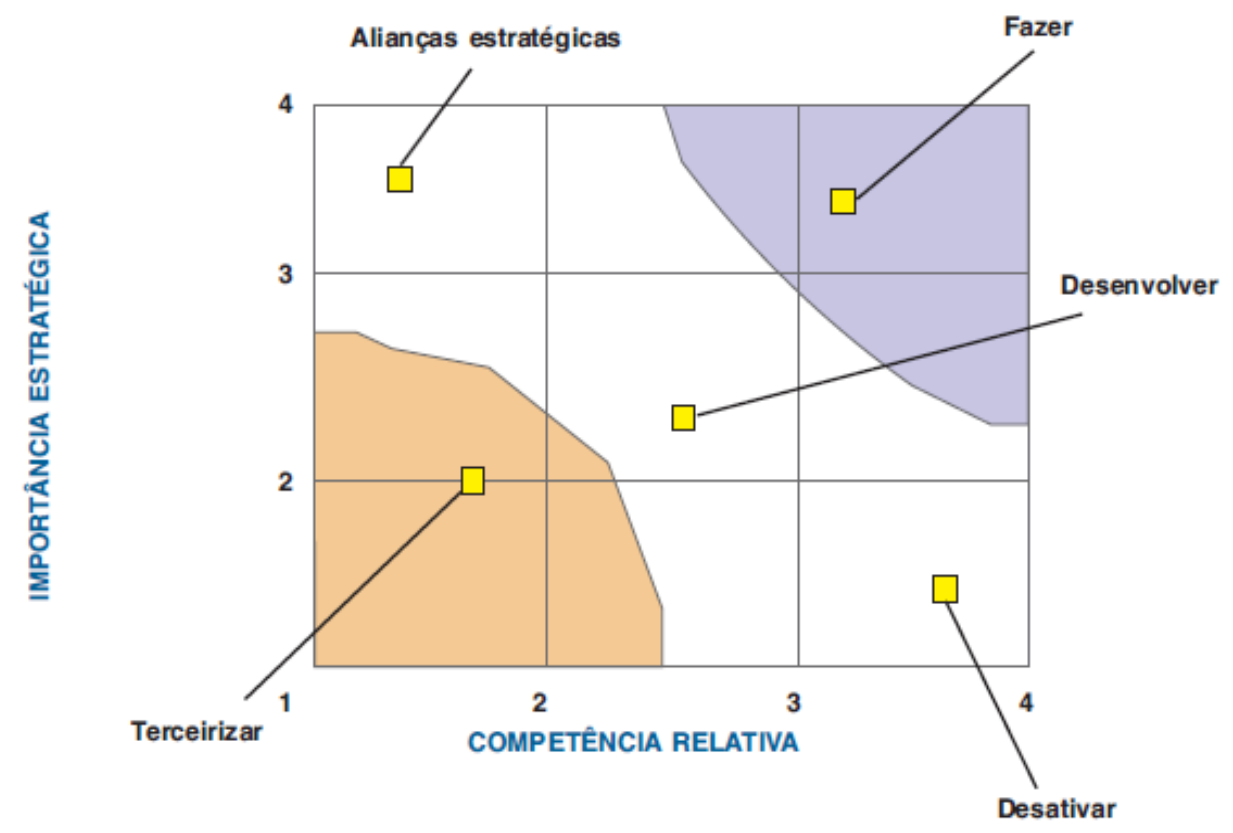

Figura 2 - Análise estratégica da decisão de fazer ou comprar.

Fonte: Adaptado de Hamel e Prahalad (1994).

\subsection{Estratégias Frente à Gestão de Desenvolvimento de Produto: Tecnologia, Inovação e Arquitetura do Produto}

O lançamento de novos produtos pode garantir a sobrevivência e a prosperidade das empresas, inclusive para aquelas do setor aeroespacial. Desenvolver produtos, conforme explicam Rozenfeld et al. (2006), consiste em um conjunto de atividades por meio das quais se busca chegar às especificações de um produto e de seu processo de produção para que a manufatura seja capaz de produzi-lo e acompanhá-lo após seu lançamento, considerando as necessidades do mercado, possibilidades e restrições tecnológicas, e as estratégias competitivas de produto da empresa. Martin et al. (2002) complementam dizendo que um dos objetivos principais do desenvolvimento de produto (DP) é a maximização do lucro potencial para a empresa. Os autores Rozenfeld et al. (2006) apresentam um modelo padrão para empresas de bens de capital e consumo duráveis conforme a Figura 3. 

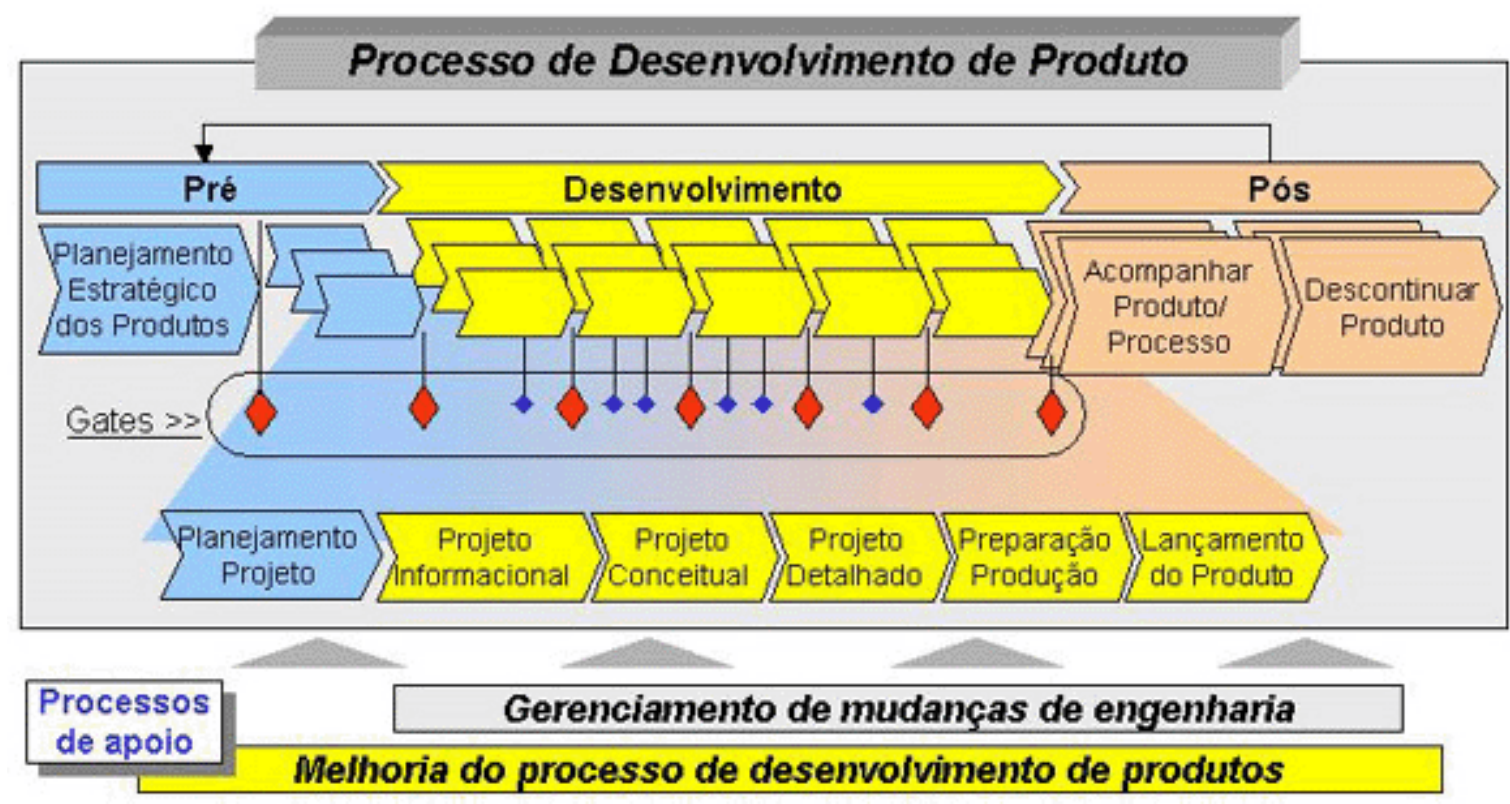

Figura 3 - Processo de desenvolvimento de produto

Fonte: Rozenfeld et al. (2006, p.44).

O modelo ilustrado na Figura 3 é dividido em macrofases, fases, atividades e tarefas. As macrofases são: pré-desenvolvimento, desenvolvimento e pósdesenvolvimento. O processo de desenvolvimento de produto é essencial para as empresas, pois, no início, o grau de incerteza é grande, mas é nesse momento que as escolhas de soluções de projeto (comprar ou fabricar, escolher os materiais e fornecedores etc.) determinarão aproximadamente $85 \%$ do custo final do produto, conforme explicam Rozenfeld et al. (2006).

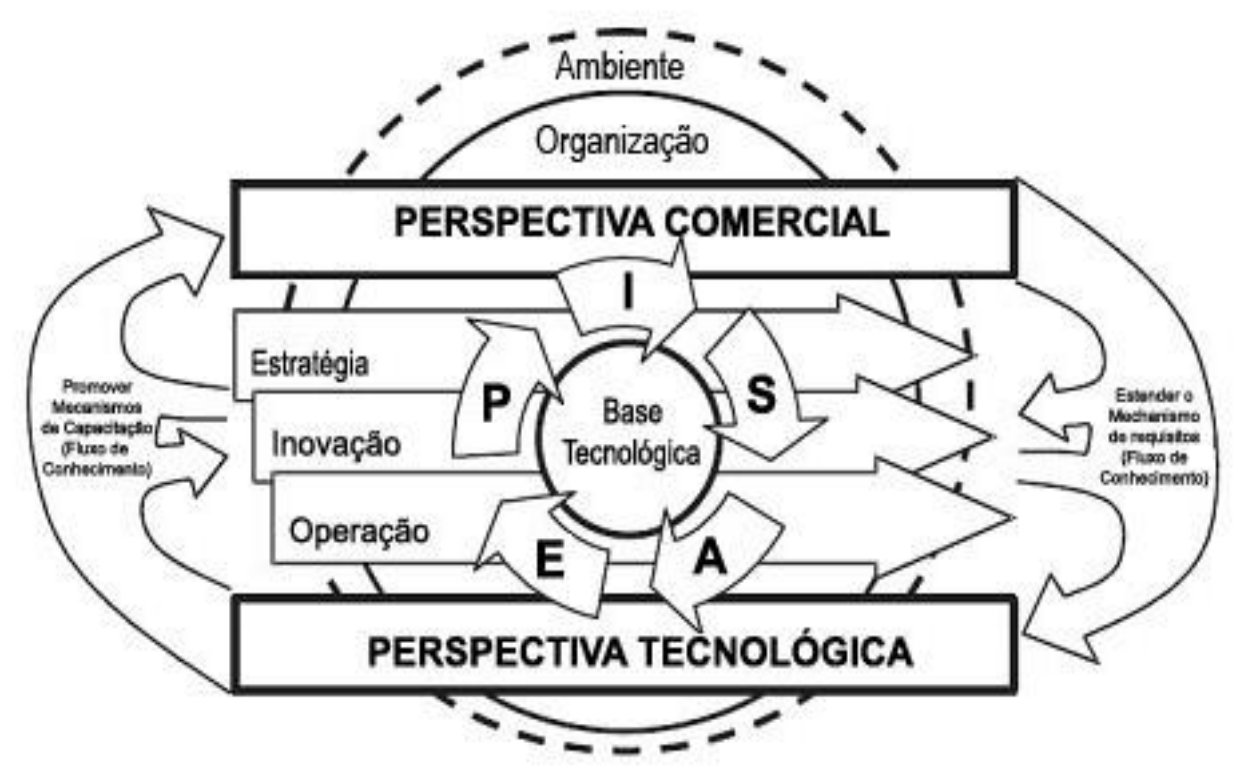

Figura 4 - Gestão de Tecnologia versus Gestão de Negócios Fonte Probert et al. (2000) apud Phall et al. (2004, p.8). 
As atividades relacionadas ao processo de desenvolvimento de produto envolvem diferentes áreas da empresa, complementa Rozenfeld et al. (2006): marketing, pesquisa e desenvolvimento, engenharia do produto, suprimentos, manufatura e distribuição. O envolvimento de diversas áreas é de fundamental importância, uma vez que, ao desenvolver um produto, a gestão de uma empresa deve avaliar as tecnologias disponíveis e as necessidades do mercado. A Figura 4 é um exemplo de uma estrutura de gestão de tecnologia versus a gestão do negócio

Na Figura 4, os autores Probert et al. (2000) mostram o processo de gestão tecnológica (identificação, seleção, aquisição, exploração e proteção) e a gestão do negócio (estratégia, inovação e operação), ressaltando a importância do diálogo entre a perspectiva tecnológica e a comercial.

Já Phall et al. (2004) complementam o conceito de desenvolvimento de produto vinculado com tecnologia e inovação com uma estrutura de um roadmaping tecnológico (ver Figura 5), a qual mostra três pilares: tecnologia alinhada com o desenvolvimento do produto, estratégia de negócio e oportunidades de mercado.

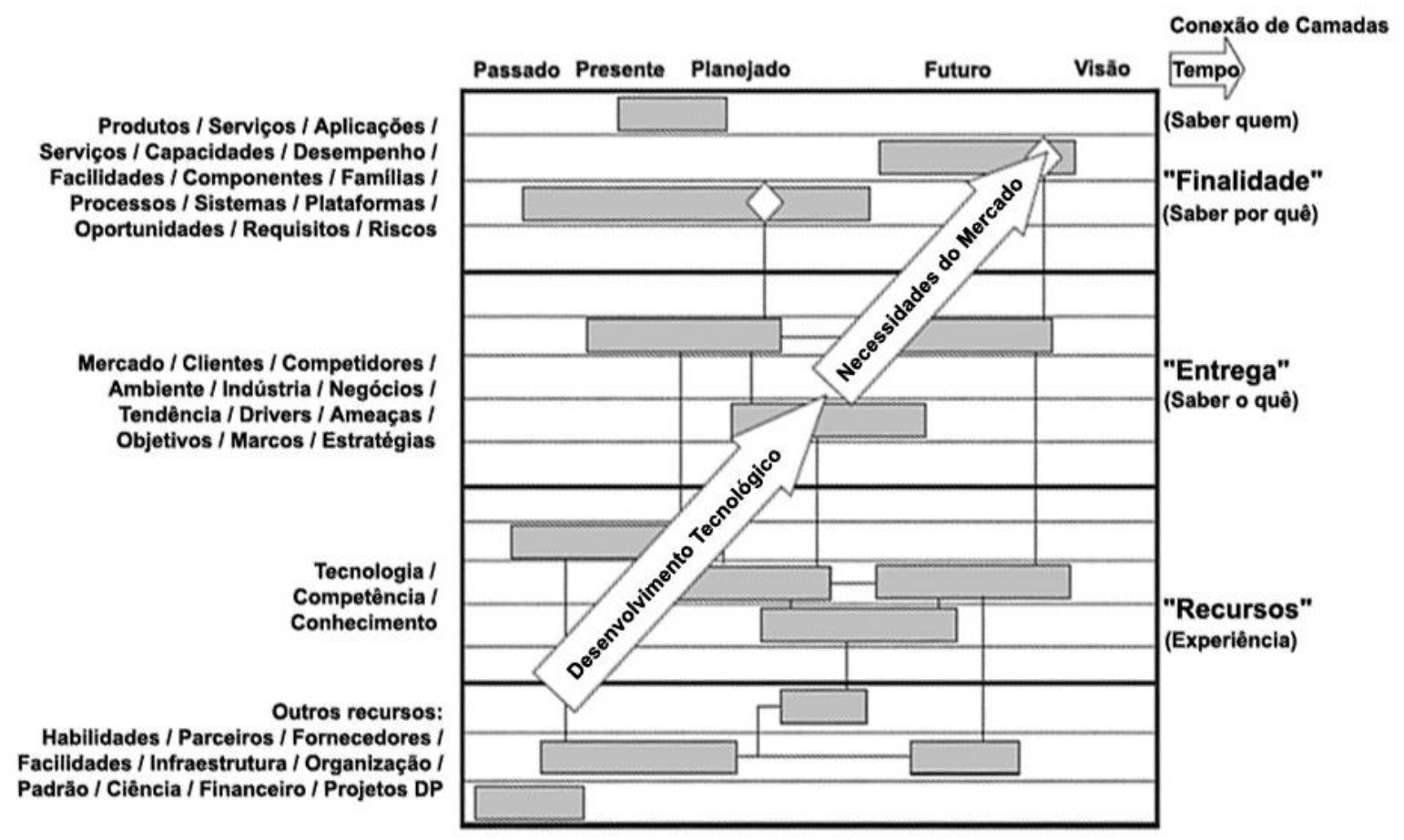

Figura 5 - Roadmap tecnológico Fonte: Phall et al. (2004, p.18).

O desenvolvimento de novos produtos deve também estar vinculado ao conceito de inovação. Tidd et al. (2001) discutem a inovação como uma vantagem estratégica (Quadro 2). 


\begin{tabular}{|l|l|}
\hline \multicolumn{1}{|c|}{ Mecanismo } & \multicolumn{1}{c|}{ Vantagem Estratégica } \\
\hline Inovação em produto ou serviço & $\begin{array}{l}\text { Oferecer algo que ninguém mais pode. Exemplo: produtos } \\
\text { inéditos. }\end{array}$ \\
\hline Inovação em processo & $\begin{array}{l}\text { Oferecer produtos de uma forma que não possam ser } \\
\text { rapidamente imitados, barateados e personalizados. }\end{array}$ \\
\hline Complexidade & $\begin{array}{l}\text { Oferecer produtos que outras empresas tenham } \\
\text { dificuldades para dominar. Exemplo: fabricantes de motor } \\
\text { de avião. Somente poucas empresas dominam essa } \\
\text { tecnologia e processo. }\end{array}$ \\
\hline $\begin{array}{l}\text { Proteção jurídica da propriedade } \\
\text { intelectual }\end{array}$ & $\begin{array}{l}\text { Oferecer produtos cujo acesso dependa de pagamento de } \\
\text { licenças ou taxas. }\end{array}$ \\
\hline Projeto robusto & $\begin{array}{l}\text { Oferecer algum produto cuja plataforma possa sofrer } \\
\text { variações e cujas novas variações possam ser } \\
\text { construídas. Exemplo: Boeing 737 cujo projeto, existente } \\
\text { há mais de 30 anos, é constantemente configurado para } \\
\text { diferentes usuários. }\end{array}$ \\
\hline
\end{tabular}

Quadro 2 - Vantagens estratégicas através da inovação

Fonte: adaptado de Tidd et al. (2001, p.7).

Ainda dentro dessa abordagem de desenvolvimento de produto, Ulrich (1995) complementa que a definição da arquitetura do produto em modular ou integral é particularmente importante no processo e nas definições das características do produto.

Fredriksson (2002), em estudo sobre a montagem modular na indústria automobilística, mostra que, devido ao fato de as montadoras adotarem o conceito de arquitetura modular, a cadeia de suprimentos adquire conhecimento sobre integração de componentes para a realização da montagem final de veículos.

Portanto, é na fase de desenvolvimento de produto que sua arquitetura deve ser decidida (modular ou integral) e essa decisão impactará a arquitetura da cadeia de suprimentos (integral/vertical ou modular/horizontal), como veremos nas próximas subseções.

\subsection{Modularidade}

A modularidade atualmente é vista em um sentido mais amplo e tem sido discutida sob muitas formas: sob o escopo da produção (linha de montagem) ou de estratégia de projeto. Estudiosos no assunto como Lung et al. (1999) discorrem sobre a modularidade no Brasil e na Europa, e Baldwin e Clark (1997) propõem a 
categorização da modularidade em projeto, produção e uso.

Para Salerno et al. (2009), a concepção de modularidade pode ser entendida sob o escopo do projeto, suprimentos e montagem. O Brasil, por volta de 1990, recebeu muitas unidades industriais com algum grau de relação de fornecimento modular, especialmente para o mercado de veículos, como o exemplo do Palio da Fiat, do Fox da Volkswagen e do Celta da General Motors (DIAS; SALERNO, 1999), conforme detalha o Quadro 3.

\begin{tabular}{|l|l|l|}
\hline \multicolumn{1}{|c|}{ FIAT } & \multicolumn{1}{|c|}{ VW } & \multicolumn{1}{c|}{ GM } \\
\hline $\begin{array}{l}\text { Brasil participa no } \\
\text { desenvolvimento de vários } \\
\text { módulos e derivativos. O Brasil }\end{array}$ & $\begin{array}{l}\text { Brasil participa no } \\
\text { desenvolvimento de vários } \\
\text { é o centro de competências } \\
\text { para testes de módulos de } \\
\text { suspensão. }\end{array}$ & $\begin{array}{l}\text { O é o prasil sedia um dos cincolipal centro de projetos } \\
\text { centros mundiais de Pesquisa e }\end{array}$ \\
fora da matriz. & \\
\hline
\end{tabular}

Quadro 3 - Participação brasileira nos projetos das montadoras

Fonte: Adaptado de Dias (2003) e Salerno et al. (2009).

O Brasil foi submetido a experimentos de arranjos industriais, que atribuíam uma nova regra para os fornecedores diretos. Estes foram requisitados a entregar subconjuntos (módulos) ao invés de partes isoladas (LUNG et al.,1999). O projeto do produto modular obedece aos seguintes critérios: 1) parâmetros e funções do módulo são interdependentes internamente; e 2) parâmetros e funções do módulo são independentes externamente com relação aos demais módulos (BALDWIN; CLARK, 1997).

Por isso, um módulo não depende de outro para ser produzido, e pequenas alterações no conceito do módulo não interferem no funcionamento do produto (HENDERSON; CLARK, 1990 apud BALDWIN; CLARK, 1997). Esse fato ressalta uma das vantagens potenciais do projeto modular: a redução da complexidade do gerenciamento do desenvolvimento do produto devido à independência entre os módulos, explica Dias (2003). A independência entre os módulos faz com que seja possível projetá-los em lugares distintos, por diferentes equipes, desde que haja uma coordenação de integração para a montagem do produto final, complementa Dias (2003). Esse fato é comum na indústria aeronáutica, em que os principais módulos (aviônica, propulsão e estrutura) são projetados em seus fornecedores, localizados a uma certa distância da montadora.

Ainda referente à concepção de modularidade, Salerno et al. (2008, p. 377) complementam: 
Além disso, nossa própria interpretação de modularidade atual inclui outras atividades além do projeto ou entrega física: um consórcio modular, condomínio industrial ou a divisão de riscos e investimentos com os fornecedores de primeiro nível; eles também assumem a responsabilidade por alguns serviços, como assistência técnica para a submontagem e participam diretamente na solução de problemas na linha de montagem, de forma a cooperar com mudanças de planejamento, pequenas mudanças no projeto do produto, entre outros.

Num condomínio industrial, fornecedores de primeira linha de componentes ou subconjuntos localizam-se ao redor da montadora, no terreno da própria fábrica, às vezes dentro desta. O condomínio industrial é caracterizado pela atuação da montadora como orientadora da estratégia de todas as empresas do condomínio (DIAS; SALERNO, 1999).

Já a concepção de consórcio modular surgiu com a fábrica de caminhões da Volkswagen (VW) em Resende em 1995. Nesse caso, o fornecedor não apenas se instala na planta da montadora e entrega seu subconjunto, mas também é responsável por sua montagem no produto final, explicam Salerno (2001) e Marx et al. (1997).

O acordo formal entre a VW e os fornecedores modulistas não é público, mas, segundo estudos apontados por Salerno (2001), o que se percebe é que, além das cláusulas de redução de preço e garantias de fornecimento, há aquelas relacionadas à amortização do capital investido e ao modo como os fornecedores modulistas são pagos. Há uma parte fixa do pagamento, independentemente do volume de produção, relacionada à amortização, como se a VW tivesse emprestado dinheiro dos fornecedores. A parte variável depende da produção após a aprovação da auditoria da qualidade da VW.

$\mathrm{Na}$ indústria de computadores, a modularidade no projeto do produto acelerou o ritmo de mudanças tecnológicas, aumentou a competição e transformou as relações empresariais. Conforme explicam Baldwin e Clark (1997), a concorrência entre os fornecedores de módulos fez com que eles partissem em busca das melhores soluções, desempenhos e atributos para seus módulos. Ainda, um produto de arquitetura modular é utilizado para construir produtos complexos, com base na definição de unidades padronizadas de maior funcionalidade do que um projeto integral, o que possibilita uma simplificação na sua desmontagem e remontagem.

Prieto (2007) explica que quanto maior o grau de modularidade de um produto, maior o tempo necessário para o desenvolvimento de seus componentes em sua fase inicial de projeto, mas, ao longo do processo, diminui o tempo de 
desenvolvimento na medida em que suas interações começam a ser mais bem definidas. Graziadio (2004) considera que modularidade significa produzir componentes (elementos) de um produto ou processo complexo de modo independente, por empresas diferentes, para que depois outra empresa monte os sistemas formando o conjunto conforme previsto.

Nessa abordagem, a externalização, transferência de atividades e responsabilidades aos fornecedores dos módulos, é parte da modularidade. A externalização é uma estratégia que opta pela combinação da modularidade do produto e a transferência de suas atividades de desenvolvimento. No entanto, cabe ressaltar que os módulos podem ser produzidos internamente pela própria empresa.

A modularidade combinada com a externalização pode ser considerada uma decisão que está mais relacionada à gestão do negócio do que com a produção. É uma forma de a empresa reduzir o volume de investimentos e os riscos associados a determinada atividade industrial, e dedicar-se ao que mais agrega valor, como projeto de plataforma, conceito do produto, motor (GRAZIADIO, 2004).

Segundo Hoek e Weken (1998), os benefícios potenciais da modularidade incluem:

- Economias de escala: a partir do momento em que cada módulo é produzido em quantidades relativamente grandes.

- Mudanças de projeto realizadas de forma independente: desde que as interfaces entre os módulos sejam claramente especificadas.

- Aumento da variedade no portfólio de produtos: a utilização de módulos significa que uma grande variedade deles pode ser alcançada através de diferentes combinações de módulos.

- Redução no lead-time de entrega: o lead-time total pode ser diminuído porque os módulos podem ser manufaturados simultaneamente.

- Divisão de tarefas: a partir do momento que as interfaces e os módulos são padronizados, suas interfaces permitem que as atividades de projeto e produção sejam decompostas.

- Facilidade de atualização, manutenção, reparo e disponibilidade: a partir do momento que um produto é decomposto em módulos.

Por fim, a modularidade deve ser entendida como algo além de entrega de submontagens; ela significa uma forma de gestão e organização ligando 
fornecedores e montadoras, com o objetivo de reduzir custos fixos pela vulnerabilidade e pelos serviços, entendendo a vulnerabilidade ligada a dois conceitos: ao processo de produção e também a dos investimentos, ligada aos custos fixos, conforme Salerno, 2001.

\subsubsection{Formas Organizacionais: Integração Vertical x Desintegração}

Sturgeon (2002), através de estudo sobre a indústria eletrônica, traz o conceito de Redes de Produção Modular. Nesse modelo de organização, as empresas líderes concentram suas atividades na criação, penetração e defesa do mercado para seus produtos finais, enquanto as atividades de manufatura passam a ser desenvolvidas por fornecedores globais. Essa forma de organização permite o estabelecimento de relações interempresas e uma capacidade genérica de produção junto aos fornecedores, levando à redução de custos, construindo economias de escala e levando as empresas líderes a se concentrarem em atividades de inovação e desenvolvimento de produto. 
A) Integração Vertical

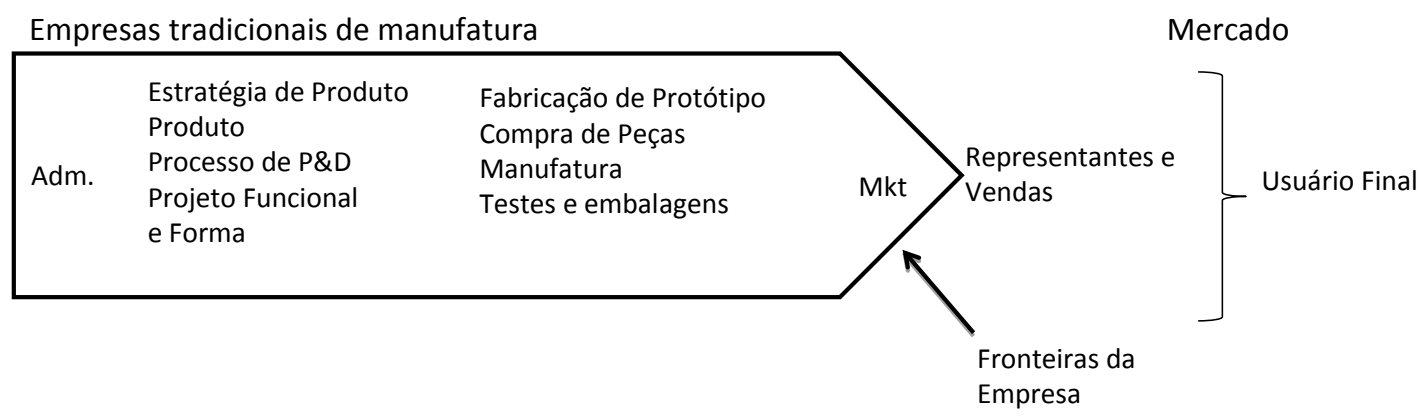

B) Organização modular

Detentores de marca Fabricante contratado

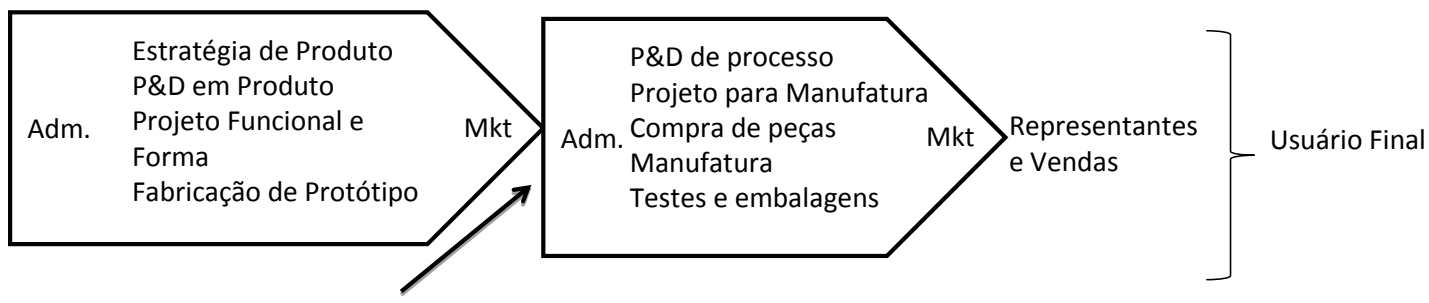

Transferência de especificações codificadas

(CAE,CAD,CAM,EDI,SCM) através de ligação inter firma

Figura 6 - Integração vertical versus Organização modular

Fonte: adaptado de Sturgeon (2002, p. 25).

Sturgeon (2002) faz uma comparação entre a estrutura vertical e a modular (Figura 6), sendo a principal diferença a capacidade na modular de separar as atividades de manufatura e de inovação de produto. $\mathrm{Na}$ organização modular, a estrutura da indústria não é verticalmente integrada; as economias de escala são alcançadas através da especialização em processos base desenvolvidos pelos fornecedores que, por sua vez, possibilitam a integração horizontal.

O Quadro 4 traz uma comparação entre as características da organização modular, segundo Sturgeon (2002), e as características da empresa integrada verticalmente segundo Chandler (1977) apud Sturgeon (2002), que, por sua vez, focou nas grandes corporações integradas verticalmente e estudadas na forma multidivisional. 


\begin{tabular}{|l|l|}
\hline \multicolumn{1}{|c|}{ Organização Modular } & \multicolumn{1}{c|}{ Organização Integrada Verticalmente } \\
\hline $\begin{array}{l}\text { Rede de produção modular tem um maior } \\
\text { rendimento de desempenho econômico do que } \\
\text { outros modelos de organização }\end{array}$ & $\begin{array}{l}\text { Custos de transação são menores dentro da } \\
\text { empresa porque podem ser mais bem } \\
\text { rotinizados }\end{array}$ \\
\hline $\begin{array}{l}\text { A empresa se ajusta mais facilmente à } \\
\text { volatilidade da demanda: não há gastos com } \\
\text { equipamentos e plantas adicionais, por exemplo }\end{array}$ & $\begin{array}{l}\text { Informaçães no preço e no fornecimento são } \\
\text { mais precisas quando transmitidas dentro da } \\
\text { empresa }\end{array}$ \\
\hline $\begin{array}{l}\text { Possibilita à empresa concentrar-se no projeto } \\
\text { de inovação do produto e vendas, e se torna } \\
\text { mais flexível organizacional e geograficamente }\end{array}$ & $\begin{array}{l}\text { Há uma melhor coordenação de entradas e } \\
\text { saídas da produção conduzindo a uma melhor } \\
\text { utilização de plantas e equipamentos }\end{array}$ \\
\hline $\begin{array}{l}\text { Fornecedores podem ser beneficiados com } \\
\text { economias de escala se tiverem um número } \\
\text { variado de clientes e usarem tecnologias } \\
\text { genéricas, além de oferecer extensão de seus } \\
\text { serviços }\end{array}$ & $\begin{array}{l}\text { Esta forma defende a defesa da propriedade } \\
\text { intelectual e a forte integração entre inovação e } \\
\text { processo }\end{array}$ \\
\hline $\begin{array}{l}\text { Aumento de processos codificados e } \\
\text { padronizados (padronização das interfaces) }\end{array}$ & $\begin{array}{l}\text { Forma organizacional: integrada vertical e } \\
\text { horizontalmente }\end{array}$ \\
\hline $\begin{array}{l}\text { Forma organizacional: desintegrada } \\
\text { verticalmente e integrada horizontalmente }\end{array}$ & \\
\hline Diminui custos de produção e inventário & \\
\hline
\end{tabular}

Quadro 4 - Organização modular versus Organização integrada verticalmente

Fonte: adaptado de Sturgeon (2002) e Chandler (1977) apud Sturgeon (2002).

Langlois (2001) também destaca a rede modular como forma de organização da produção. Segundo o autor, esse modelo de organização teve início a partir de importantes mudanças nas tecnologias de produção, de forma que a verticalização das unidades passa a ser substituída pelas especializações e a produção passa a ser realizada por várias empresas distintas. Langlois (2001) argumenta que, impulsionado pelo aumento da população e da renda e pela redução das barreiras tecnológicas e legais do comércio, o processo de divisão do trabalho tende a levar a uma especialização das funções coordenadas pelos mercados.

O Quadro 5 apresenta as principais características da Organização Modular e da Organização Vertical sob o ponto de vista de Langlois (2001).

\begin{tabular}{|l|l|}
\hline \multicolumn{1}{|c|}{ Organização Modular } & \multicolumn{1}{c|}{ Organização Vertical } \\
\hline $\begin{array}{l}\text { As interações entre os módulos são reduzidas ao } \\
\text { mínimo e regularizadas através de interfaces } \\
\text { formais }\end{array}$ & $\begin{array}{l}\text { Estrutura unificada com uma única divisão de } \\
\text { responsabilidade administrativa }\end{array}$ \\
\hline $\begin{array}{l}\text { As empresas subcontratadas são generalistas, a } \\
\text { relação entre elas e seus clientes (empresas } \\
\text { contratantes) é puramente comercial }\end{array}$ & $\begin{array}{l}\text { Integração vertical pode superar os custos de } \\
\text { transação, é mais econômico integrar os } \\
\text { muitos estágios complementares face aos } \\
\text { custos dinâmicos transacionais }\end{array}$ \\
\hline $\begin{array}{l}\text { Padronização técnica é a principal característica: } \\
\text { ela permite a coordenação e reduz a necessidade } \\
\text { de transferência de muitas informações para as } \\
\text { empresas subcontratadas }\end{array}$ & $\begin{array}{l}\text { O controle centralizado ajuda a superar a visão } \\
\text { estreita dos participantes locais }\end{array}$ \\
\hline
\end{tabular}




\begin{tabular}{|l|l|}
\hline \multicolumn{1}{|c|}{ Organização Modular } & \multicolumn{1}{c|}{ Organização Vertical } \\
\hline $\begin{array}{l}\text { O sistema modular pode se beneficiar das } \\
\text { capacidades externas da economia como um } \\
\text { todo: grande número de profissionais, habilidades } \\
\text { acumuladas, experiência e tecnologias } \\
\text { disponíveis para os participantes do mercado }\end{array}$ & $\begin{array}{l}\text { Apesar de haver especialização das funções e } \\
\text { divisão do trabalho há uma redução da } \\
\text { especialização em nível gerencial; o gestor é } \\
\text { generalista, os gerentes supervisionam } \\
\text { múltiplos estágios da produção }\end{array}$ \\
\hline $\begin{array}{l}\text { Gera economias de substituição, ou seja, não se } \\
\text { limita aos recursos corporativos, mas pode valer- } \\
\text { se dos melhores módulos que o mercado pode } \\
\text { oferecer }\end{array}$ & $\begin{array}{l}\text { A natureza da aprendizagem dentro de uma } \\
\text { estrutura verticalmente integrada pode reforçar } \\
\text { a integração }\end{array}$ \\
\hline $\begin{array}{l}\text { Sistema modular pode estimular a inovação, está } \\
\text { inserido em um contexto de tamanho de mercado } \\
\text { maior e maior complexidade }\end{array}$ & $\begin{array}{l}\text { A estrutura vertical pode persistir se o } \\
\text { ambiente em que a empresa opera não for } \\
\text { rigoroso suficiente para exigir mudanças }\end{array}$ \\
\hline & $\begin{array}{l}\text { Estrutura vertical pode ser a solução } \\
\text { apropriada para problemas de projeto }\end{array}$ \\
\hline & $\begin{array}{l}\text { Quando o mercado se torna mais competitivo, } \\
\text { os benefícios da integração vertical se } \\
\text { reduzem }\end{array}$ \\
\hline
\end{tabular}

Quadro 5 - Organização modular versus Organização vertical segundo Langlois Fonte: adaptado de Langlois (2001).

Assim, Langlois (2001) coloca que o sistema modular não foi conduzido apenas pelas mudanças tecnológicas, mas pelas mudanças na dimensão dos mercados, pelo aumento da população e da renda e pela globalização.

Malerba et al. (2008) apresentam um modelo que analisa a mudança vertical na indústria de computadores. A hipótese básica do modelo é que a principal força por trás dos padrões de integração vertical e desintegração das empresas desse setor foi o desenvolvimento diferenciado da capacidade de projeto e produção de semicondutores entre as empresas. Tal modelo mostra como os padrões da integração vertical e especializações da indústria desse setor mudam como função do nível de evolução e da capacidade de distribuição das empresas ao longo do tempo, e como eles dependem da coevolução dos setores acima e abaixo.

Malerba et al. (2008) afirmam que as teorias sobre integração vertical e especialização se baseiam principalmente nos custos de transação, nas escolhas sobre a integração e na eficiência relativa dos mercados versus a hierarquia das empresas, que são determinadas por um cálculo que pondera as vantagens do mercado e as vantagens da governança hierárquica das organizações. No entanto, para Malerba et al. (2008), o fator central para explicar o escopo vertical das empresas é o processo de acumulação de capacitações que é conseguido ao longo do tempo através da aprendizagem de tecnologias específicas, produtivas e de domínio do mercado. 
A decisão sobre a verticalização não pode ser tomada isoladamente sob o escopo da empresa, mas deve considerar os participantes da indústria e a qualidade relativa do produto na produção interna com a qualidade do produto fornecida por fontes externas. Langlois e Robertson (1995) apud Malerba et al. (2008) complementam que quando os produtos são sistemas com vários componentes e subsistemas, a capacidade de coordenar e integrar um projeto pode constituir uma competência fundamental e uma importante vantagem competitiva. A integração vertical e a especialização são, segundo Malerba et al. (2008), moldadas pela coevolução das capacitações, tamanho dos mercados e estrutura das indústrias. A capacitação se refere à acumulação de competências em determinadas tecnologias e à capacidade de coordenação e integração de componentes e sistemas de novos produtos. Segundo Malerba et al. (2008), a acumulação de capacitação pode ser afetada de várias maneiras, como apresentado no Quadro 6.

Portanto, sob o ponto de vista de Malerba et al. (2008), a decisão de estrutura vertical ou não dependerá da capacitação das empresas (acúmulo de competências), do processo de aprendizagem e seleção do mercado dos setores acima e abaixo, do tamanho do mercado, da magnitude das descontinuidades tecnológicas e dos seus efeitos na demanda.

Já Brusoni (2005) argumenta que existem limites cognitivos para a extensão da divisão do trabalho, ressaltando a importância das empresas integradoras do conhecimento em redes modulares, pois para ele o processo de aprendizagem está espalhado entre as empresas que compõe a rede. Essas empresas, contando com sua gama de conhecimentos científicos e tecnológicos, conseguem identificar, propor e implementar soluções para problemas complexos, coordenando a rede de fornecedores e as competências especializadas. A modularidade como estratégia de produto e de organização fornecerá uma primeira abordagem para entender como a coordenação do conhecimento das atividades é atingida em uma base global. A literatura sobre modularidade enfatiza o que as empresas "fazem", e não o que elas "conhecem", segundo Brusoni, 2005, sendo que o conhecimento é fundamental para a adoção de estratégia de produto modular. 
Tamanho da empresa: afeta a quantidade investida em Pesquisa e Desenvolvimento (P\&D), ou seja, o acumulo de competências, e consequentemente a qualidade dos sistemas e componentes produzidos.

Tamanho do mercado: grandes mercados permitem a entrada de novas empresas especializadas e seu crescimento.

Estrutura de mercado de duas indústrias verticalmente relacionadas: refere-se à distribuição de capacidade entre os participantes da indústria. Por exemplo, uma indústria de sistema monopolista tende a se tornar verticalmente integrada em componentes quando confrontada com a indústria acima fragmentada, composta por pequenas empresas. O contrário também pode ocorrer: uma indústria de segmentos fragmentada tende a se especializar quando confrontada com uma indústria de componentes monopolística.

Descontinuidades tecnológicas e destruição de competências relacionadas: grandes descontinuidades mudam a base de conhecimento e o tipo de demanda, permitindo a entrada e 0 crescimento das empresas que dominam a nova competência. Sob essas condições, empresas integradas verticalmente sofrem pressões no sentido da desintegração

Quadro 6 - Fatores que influem na capacitação da empresa

Fonte: adaptado de Malerba et al. (2008).

Para outros autores como Pavitt (2003), o desenvolvimento das aplicações da tecnologia da informação (TI) em atividades de projetos levou a avanços na modularização de componentes, isto é, na decomposição dos produtos em módulos ou sistemas com interfaces normatizadas. Essa decomposição facilitou a contratação externa de projeto e produção, sob restrição da arquitetura do sistema ou produto para o qual são desenhados, permitindo uma nova forma organizacional frente à forma de integração vertical que prevaleceu em quase todo o século XX.

Pavitt (2003) ainda argumenta que a integração dos sistemas foi possível entre outros motivos pelo: a) aumento da especialização da produção e b) aumento do conhecimento tecnológico. Com o aumento da especialização, os produtos se tornaram mais complexos e a aceleração de $\mathrm{Tl}$ abriu oportunidades para isso, pois as técnicas de simulação reduziram os custos de experimentos. Nesse contexto, a importância dos projetos modulares cresceu. A interface dos componentes é padronizada, possibilitando a terceirização de projetos e da produção de componentes e subsistemas. Mas a modularidade não reduz a função de integração; em sistemas complexos é importante saber liderar a integração das particularidades de cada subconjunto. E nesse sentido Pavitt (2003) ressalta a limitação na desintegração vertical pela falta de convergência tecnológica em produzir diferentes produtos, pois alguns projetistas defenderão suas competências estratégicas dificultando a sua imitação como, por exemplo, em motores de avião. $\mathrm{O}$ argumento principal de Pavitt (2003) é que por mais que a divisão do trabalho aumente, ainda será necessário o domínio da integração de componentes e subconjuntos. 
Por fim, o modelo de hélice dupla de Fine (2000) mostra a constante mudança nos setores e, consequentemente, nas cadeias de fornecimento no que se refere à forma organizacional (Figura 7). Quando a estrutura do setor é vertical e a arquitetura do produto é integral, existirão forças que pressionarão para estrutura horizontal e modular, como:

- a entrada de competidores de nicho;

- o desafio de se manter frente aos avanços tecnológicos; e

- a rigidez organizacional e a burocracia que se instalam em grandes empresas.

Essas forças enfraquecem a estrutura vertical e levam em direção a uma desintegração para uma estrutura mais horizontal e modular. Por outro lado, quando uma cadeia de suprimentos tem uma estrutura modular, ela sofre forças que a empurram para uma integração vertical e uma arquitetura integral do produto, como:

- o avanço tecnológico em um subsistema que pode torná-lo um componente escasso, dando ao proprietário poder de mercado;

- o poder de mercado em um subsistema pode encorajar a agregação em outros subsistemas, aumentando o controle e o valor agregado; e

- o poder de mercado em um subsistema pode encorajar a integração de engenharia com outros subsistemas para desenvolver soluções integradas patenteadas.

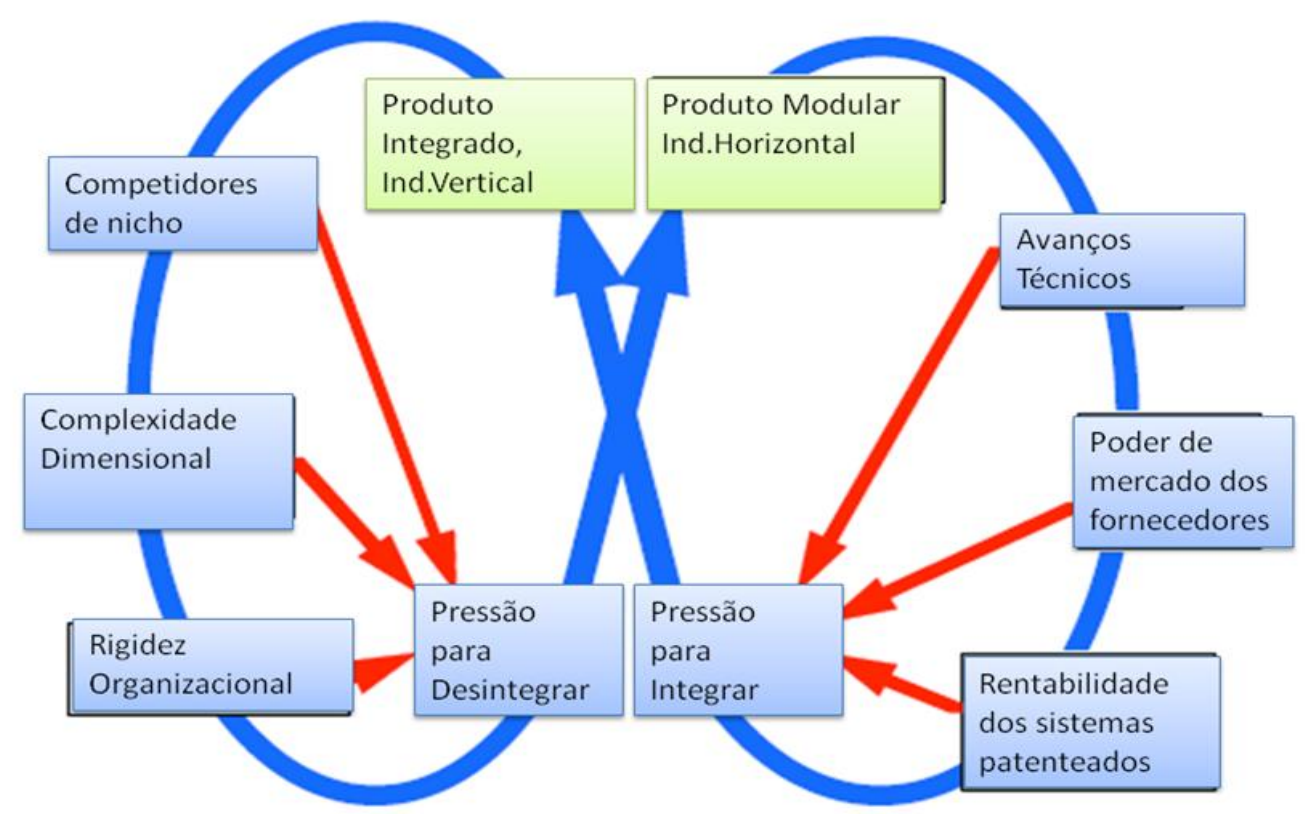

Figura 7 - Modelo de dupla hélice Fonte: adaptado de Fine (2000). 


\subsection{Estratégias Frente à Gestão de Cadeia de Fornecimento}

A estratégia de muitas empresas é diminuir o número de fornecedores diretos e projetar famílias de produtos a partir de plataforma comum, levando à busca de maior proximidade com os fornecedores. Isso tem sido particularmente estudado na indústria automobilística (SALERNO, 2001; DIAS, 2003; SALERNO et al., 2009). Esta indústria foi um referencial importante para a aeronáutica, particularmente para a Embraer, que sempre buscou agregar conhecimento de setores diversos.

Uma série de termos busca definir os diferentes processos de relação com fornecedores. Abaixo, foram selecionados alguns utilizados na automobilística (SALERNO et al., 1998):

a) Global sourcing: é uma estratégia das montadoras de busca e definição de seus fornecedores em bases globais, não importando sua localização geográfica e sua origem nacional.

b) Follow sourcing: permite ao fornecedor que desenvolveu uma peça ou parte acompanhar a montadora, estabelecendo-se nos locais em que se produzirão os veículos que se utilizam dela. Isso tem provocado na cadeia automotiva uma predominância, no primeiro nível de fornecimento, de empresas de capital estrangeiro (transacionais), e implicou, no Brasil, em uma desnacionalização dos ativos do setor de autopeças.

c) Co-design: permite ao fornecedor compartilhar 0 projeto de desenvolvimento de peças, partes ou módulos juntamente com a empresa contratante, em alguns casos assumindo por inteiro o desenvolvimento e homologação do referido sistema, dentro das condições de qualidade asseguradas, garantindo ao fornecedor domínio tecnológico (know-how) no segmento. Isso implica que a cadeia é potencialmente impactada pela liderança tecnológica dos fornecedores de primeiro nível (first tiers).

d) Carry-Over-Parts: permite à empresa contratante utilizar peças ou conjuntos já desenvolvidos em projetos anteriores, otimizando a 
utilização de itens da série de um produto existente no novo projeto. Aqui, são relevantes as questões estratégicas mundiais de unificação de plataformas na construção dos diversos modelos de produtos.

Já o termo "parceiro" pode apresentar muitos significados, sendo menos preciso do que os que se encontram acima, e apesar de ser muito utilizado, seu significado varia de acordo com cada segmento. Por isso, foi adotada a definição de Bastos (2006, p. 45), aplicada para indústria aeronáutica:

e) Parceiro de risco: permite ao fornecedor assumir riscos financeiros na fase de desenvolvimento dos projetos. Esses parceiros participam no desenvolvimento conjunto do produto e no estabelecimento das especificações técnicas, agregam tecnologia, sendo responsáveis pelo fornecimento de sistemas e submontagens completas (como motores, aviônica, fuselagem), que serão integrados na montagem final. A aeronave é projetada para acomodar determinado tipo de componente, o qual dificilmente poderá ser substituído por outro fornecedor; se isso ocorrer poderá acarretar em atraso e enormes gastos adicionais. Essa dependência, de acordo com Bernardes e Pinho (2002), torna a empresa suscetível ao desempenho, qualidade e condições financeiras de seus parceiros de risco.

\subsubsection{Gestão de Parcerias: Alianças Estratégicas}

Quase todo processo de inovação demanda alguma forma de colaboração ou parceria para o desenvolvimento comercial de um produto. Tidd et al. (2001) mencionam que as empresas colaboram por diversas razões: para reduzir os custos do desenvolvimento tecnológico ou permitir a entrada no mercado;reduzir os riscos de desenvolvimento; atingir economias de escala na produção; e reduzir o tempo para desenvolver e comercializar novos produtos.

Uma aliança estratégica é constituída, segundo Lorange e Roos (1996), quando os parceiros formam um empreendimento novo, e apresenta como característica principal a intenção de mover cada participante em direção a um 
objetivo estratégico comum de longo prazo, resultando em fortalecimento das posições competitivas dos parceiros.

Tidd et al. (2001) complementam explicando que a empresa tem vários motivos para uma aliança, conforme Figura 8. Para os autores, os motivos estratégicos e táticos que levam à colaboração envolvem fatores tecnológicos, organizacionais e de mercado. Razões tecnológicas envolvem tempo, custo e complexidade de desenvolvimento. Acrescentam, ainda, que dois fatores devem ser levados em consideração nas decisões de comprar ou fabricar: os custos transacionais e as implicações estratégicas. Já para Lorange e Roos (1996) existem somente quatro razões que levam à parceria: defesa - para defender posição de liderança ao aprender com a aliança novas habilidades; conquista - para obter novos mercados e atacar a empresa líder; permanência - para continuar o negócio que é secundário no seu portfólio; e restauração - para revitalizar ou reconfigurar o negócio.

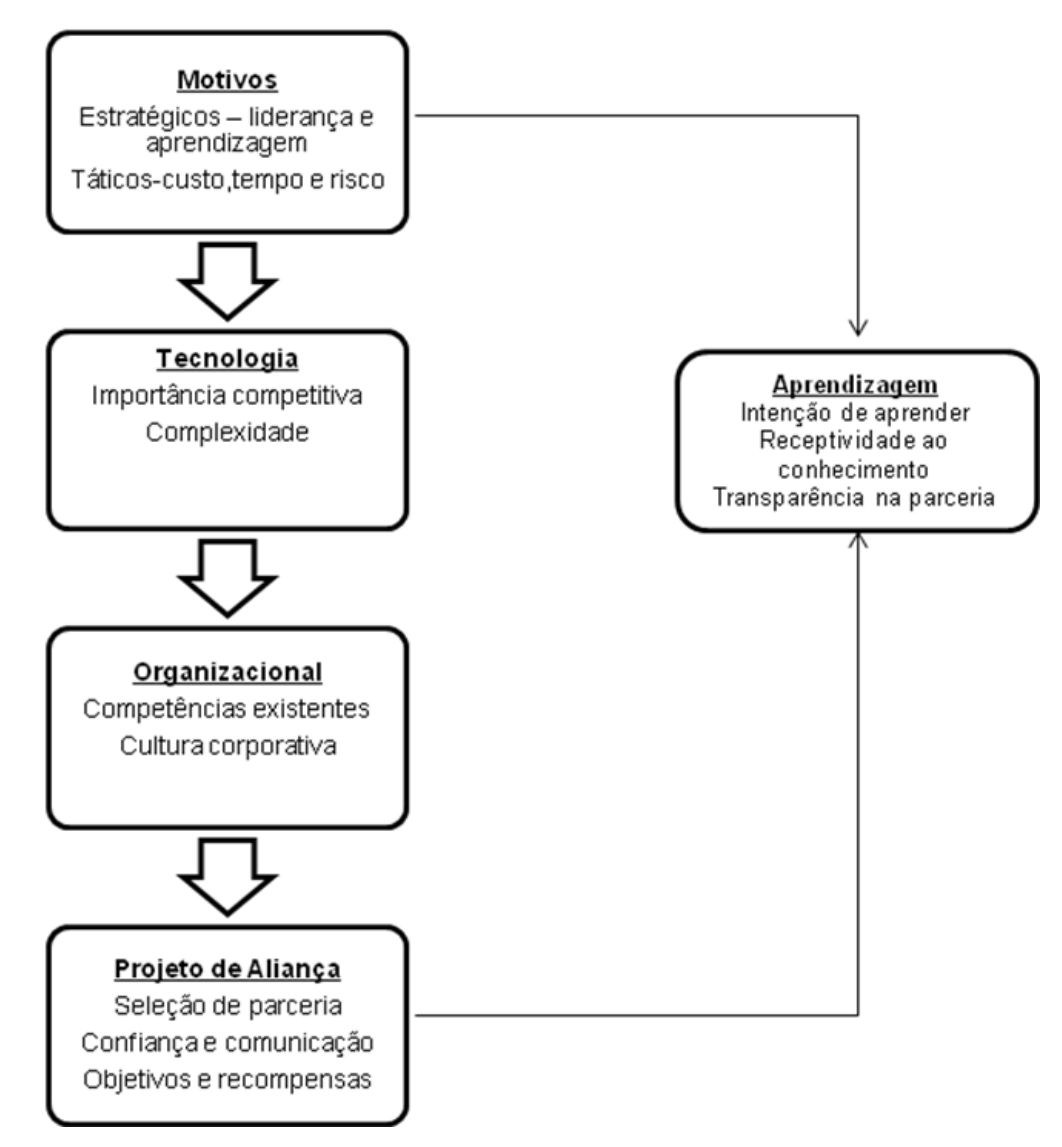

Figura 8 - Modelo de colaboração

Fonte: adaptado de Tidd et al. (2001, p.199).

Para Klotzle (2002), apenas duas teorias justificam as alianças estratégicas: 
a teoria dos recursos organizacionais e a teoria de aprendizagem. Isso porque as alianças são usadas pelas empresas para ganhar acesso aos recursos valiosos das parcerias, ou para ter acesso à transferência de conhecimento e habilidades que ocorrem no decorrer da relação.

Klotzle (2002) traz um resumo das definições de alianças estratégicas encontradas na literatura:

\begin{tabular}{|c|c|}
\hline Autor & Definição de Alianças Estratégicas \\
\hline Teece (1992) & $\begin{array}{l}\text { Acordos nos quais dois ou mais parceiros dividem o compromisso de alcançar } \\
\text { um objetivo comum, unindo todas as suas capacidades e recursos e } \\
\text { coordenando suas atividades. Uma aliança estratégica implica um grau de } \\
\text { coordenação estratégica e operacional das atividades e inclui, entre outras, } \\
\text { as seguintes operações: atividades conjuntas de Pesquisa e Desenvolvimento } \\
\text { (P\&D), transferência mútua de tecnologia, concessão de direitos exclusivos } \\
\text { de produção e vendas e acordos de cooperação na área de marketing. } \\
\text { Alianças estratégicas podem ou não envolver participação acionária. }\end{array}$ \\
\hline $\begin{array}{l}\text { Hagedoorn e Narula } \\
\text { (1996) }\end{array}$ & $\begin{array}{l}\text { As alianças estratégias podem ser classificadas de duas maneiras. De um } \\
\text { lado existem tipos que envolvem participação acionária, como joint-ventures e } \\
\text { companhias conjuntas de pesquisa. De outro lado há formas sem participação } \\
\text { acionária, baseadas em contratos entre parceiros. Nesse grupo encontram-se } \\
\text { acordos de desenvolvimento conjunto de produtos, pacotes de pesquisa } \\
\text { conjunta, acordos mútuos de licenciamento e contratos de Pesquisa e } \\
\text { Desenvolvimento (P\&D). }\end{array}$ \\
\hline $\begin{array}{l}\text { Dussauge e Garrette } \\
(1995,1997)\end{array}$ & $\begin{array}{l}\text { Projetos de colaboração implantados por empresas rivais, operando na } \\
\text { mesma indústria. As empresas mantêm, entretanto, a sua independência. } \\
\text { Essa definição exclui, assim, fusões e aquisições, as quais levam à perda de } \\
\text { autonomia de pelo menos um parceiro. Também são excluídas parcerias } \\
\text { verticais formadas por fornecedores e compradores. }\end{array}$ \\
\hline $\begin{array}{l}\text { Lorange e Roos } \\
\text { (1996) }\end{array}$ & $\begin{array}{l}\text { Empreendimento de risco ao longo de uma escala contínua entre, de um lado, } \\
\text { transações em um mercado livre (mercado) e, de outro, a internalização total } \\
\text { (hierarquia). Temos, assim, as seguintes opções de alianças estratégicas em } \\
\text { termos de grau de integração vertical com a empresa mãe: fusões e } \\
\text { aquisições, participação acionária, joint-venture, empreendimento cooperativo } \\
\text { formal e empreendimento cooperativo informal. }\end{array}$ \\
\hline Garai (1999) & $\begin{array}{l}\text { As alianças estratégicas incluem acordos de esforços conjuntos na área de } \\
\text { marketing, atividades conjuntas de Pesquisa e Desenvolvimento (P\&D), } \\
\text { colaboração no desenvolvimento de novos produtos, transferência de } \\
\text { tecnologia e atividades de terceirização. Fusões e aquisições não são } \\
\text { consideradas alianças estratégicas. }\end{array}$ \\
\hline
\end{tabular}

Quadro 7 - Definições de aliança estratégica

Fonte: Klotzle (2002, p.89).

A colaboração é definida por Monczka et al. (2009, p. 122) como "um processo pelo qual duas ou mais partes adotam um alto nível de cooperação intencional para manter uma relação comercial ao longo do tempo". Os autores ainda complementam dizendo que a colaboração é uma relação bilateral em que as partes têm o poder de moldar e direcionar essa relação; além disso, o comprometimento mútuo e uma relação de poder balanceado são essenciais para o 
relacionamento.

Humphries e Wilding (2001) entendem que a parceria é uma abordagem ampla para a gestão da cadeia de suprimentos, envolvendo tecnologia, processo e informação, baseada em confiança e comprometimento ao longo prazo, tendo como meta assegurar retornos financeiros para os membros da cadeia.

\subsection{Problemas na Seleção de Fornecedores}

A seleção e avaliação de fornecedores tornaram-se atividades importantes para as empresas em geral, estejam elas inseridas em qualquer setor. Uma forma usual de tratar os problemas de seleção de fornecedores era através do menor preço, mas a consequência disso eram trocas contínuas de fornecedores, impactando na estabilidade da qualidade do produto final.

Corrêa e Corrêa (2004) afirmam que a evolução das tecnologias de produto e processo tem ocorrido com tanta rapidez que, para manterem-se atualizadas, as empresas têm preferido delegar para terceiros parcelas cada vez mais substanciais do desenvolvimento e produção de peças e serviços. Como consequência, aumentou significativamente a quantidade e a intensidade das relações entre empresas, e estas passaram a conviver com complexas redes de suprimentos, nas quais aspectos de cooperação, desenvolvimento conjunto de produtos, parcerias e aliança tornaram-se parte integrante do novo modelo de relacionamento (BASTOS, 2006).

Nesse sentido, as empresas foram pressionadas a alterar o modelo tradicional de relacionamento de curto prazo e distante de seus fornecedores para uma relação mais estreita e de longo prazo, característica dos relacionamentos de parceria. Novos critérios para a seleção de fornecedores foram estabelecidos para tomada de decisão. Para melhor compreensão, discutiremos alguns critérios utilizados nas montadoras do setor automobilístico, dada a literatura disponível e consolidada sobre o setor. 


\subsection{Critérios para Seleção de Fornecedores nas Montadoras}

A seleção de fornecedores é uma das etapas críticas, já que selecionar o fornecedor correto em cada caso significa reduzir os riscos e os custos de transação, aumentando assim a competitividade da empresa.

Para que a etapa de seleção de fornecedores seja eficaz, originando assim uma parceria de sucesso entre comprador e fornecedor, faz-se necessário determinar os critérios de seleção a serem considerados em cada processo. Pois são os critérios de seleção que vão determinar quais pontos devem ser confrontados entre os fornecedores interessados na parceria ofertada.

Embora exista uma diferença de critérios de seleção a serem considerados em cada atividade, é necessário que as empresas se baseiem em critérios corporativos, válidos para todas as atividades, de modo a criar uma identidade junto ao mercado de fornecedores, e tornar claras suas prioridades e exigências (MOTWANI et al, 1999; LIU; DING; LALL, 2000).

Os critérios mais comumente utilizados por grandes empresas de acordo com Faria e Vanalle (2006) são preço, qualidade, prazo, flexibilidade e análise financeira, entre outros critérios administrativos. Tais características são mais bem explicadas pelos autores abaixo:

- Preço. Empresas que escolhem competir utilizando a estratégia somente de preço têm seu retorno financeiro ou margem de lucro sempre pressionados pelo mercado, pois o diferencial em relação aos concorrentes é o preço. O processo de seleção de fornecedores deve levar em conta outros fatores como pontualidade, cultura organizacional, qualidade e confiança (HELMS; DIBRELL; WRIGHT, 1997).

- Qualidade. A terceirização deve ser apoiada para preservar a qualidade já obtida e garantir um processo de melhoria contínua. Caso haja alguma possibilidade de que a qualidade dos produtos ou serviços venha a ser prejudicada, a terceirização não é racional. A qualidade mantém a 
satisfação do cliente, a motivação do empregado e, consequentemente, a produtividade com qualidade (SILVA, 1997).

- Desempenho das Entregas. O desempenho das entregas é analisado a partir de duas características: velocidade e confiabilidade. Velocidade, neste caso, é o tempo gasto por uma empresa para completar a execução de um pedido, e confiabilidade é a capacidade da empresa de realizar a entrega conforme combinado (MILGATE, 2001).

- Flexibilidade. Ao se escolher um fornecedor é importante certificar-se de que este seja capaz de responder de forma adequada às flutuações de demanda da empresa contratante. Fornecedores que possam se ajustar às necessidades e especificações com maior rapidez e precisão trarão mais benefícios (GIOSA, 1999).

- Análise Financeira. As empresas financeiramente saudáveis, com boa reputação e posição no mercado, têm condições de cumprir com seus compromissos com a empresa contratante, sejam esses compromissos relativos à confiabilidade das entregas, à qualidade de produtos ou serviços, à manutenção do custo de acordo com o negociado, à capacidade de desenvolvimento e implementação de melhorias, à manutenção de equipe técnica, equipamentos e instalações adequadas, ou, principalmente, à perspectiva de parceria em longo prazo (MIN, 1994; CHOY; LEE, 2003).

- Análise de Critérios Administrativos. A empresa selecionada deve estar legalmente constituída para atuar no ramo de atividade terceirizada, com capacitação técnica e administrativa. A mão de obra deve ser especializada, adequadamente remunerada, com os direitos trabalhistas respeitados, para que não haja problemas no decorrer da parceria (PINTO; XAVIER, 2002).

As decisões de compra não são mais tomadas exclusivamente pelas equipes de compra, apesar da maior visibilidade da área na organização. De fato, conforme explica Lima (2004), as equipes de compra, engenharia de produto, qualidade, logística e finanças da montadora decidem, em conjunto, quem irá fornecer, considerando os seguintes fatores para o setor automobilístico: certificação de qualidade (QS/ISO), capacidade financeira, qualificação do processo produtivo, capacidade de engenharia e histórico de fornecimento. Lima (2004) complementa 
dizendo que o preço é o fator ganhador de pedidos, já que somente são homologadas como fornecedores potenciais as empresas que apresentam os fatores qualificadores anteriormente mencionados.

\subsection{Fornecedor Estratégico}

Camuffo (2000), analisando o setor automobilístico, considera que fornecedor de primeiro nível é aquele que provê serviços completos para as montadoras através do suprimento e montagem de módulos e submódulos em larga escala. Frequentemente, possuem uma ampla variedade de capacitações tecnológicas avançadas, incluindo pesquisa e desenvolvimento, que proporcionam um fluxo de produção constante para os módulos de montagem automotivos, entregam e montam seus componentes diretamente na planta dos seus clientes (montadoras), e estão capacitados a gerenciar as condições de qualidade e entrega dos seus produtos e dos fornecedores dos outros níveis na cadeia de suprimentos.

Como forma de aumentar o valor agregado ao produto, grande parte desses fornecedores estratégicos de primeiro nível estão assumindo novas funções (entrega sincronizada, co-design e suporte global) e progressivamente se capacitando e se adequando ao conceito de fornecimento modular, em que assumem a responsabilidade pela montagem das peças ou submódulos em um único módulo que constitui um sistema (COLLINS; BECHLER; PIRES, 1997).

No entanto, neste processo de aproximação entre as empresas (também conhecidas como "contratantes principais" ou Original Equipment Manufacturers OEMs) e fornecedores estratégicos de primeiro nível, as pequenas e médias empresas (segundo e terceiro níveis) estão, progressivamente, se posicionando em um patamar inferior de comprometimento e contribuição direta às empresas. Esse fato é devido às suas limitações no nível de capacitação tecnológica com ênfase nas atividades rotineiras de produção e fornecimento de peças ou módulos simples.

Conforme mostra a Figura 9, dentro da indústria automobilística o que se pode observar é que os fornecedores do segundo nível da cadeia de suprimentos tendem a progressivamente fornecer seus produtos diretamente às empresas que 
estão no primeiro nível da cadeia de suprimentos. O segundo nível da cadeia é constituído por um grande número de pequenas e médias empresas. As empresas de terceiro nível são fornecedoras de commodities para as de primeiro e segundo níveis.

$\mathrm{Na}$ estrutura tradicional, muito comum nos casos de condomínios industriais, segundo estudos de Salerno (2001) e Prieto (2007), os fornecedores de primeiro e segundo níveis não estão claramente definidos e, de forma geral, ambos possuem contato direto com a montadora. Já na estrutura em forma de tierings na figura abaixo, os níveis (primeiro, segundo e terceiro) são claramente definidos e, de forma geral, somente o primeiro possui relação direta com a montadora. Nesse processo o fornecedor de primeiro nível assume a responsabilidade pela montagem de módulos e os fornecedores de segundo e terceiro níveis (geralmente pequenas e médias empresas) fornecem componentes e peças.

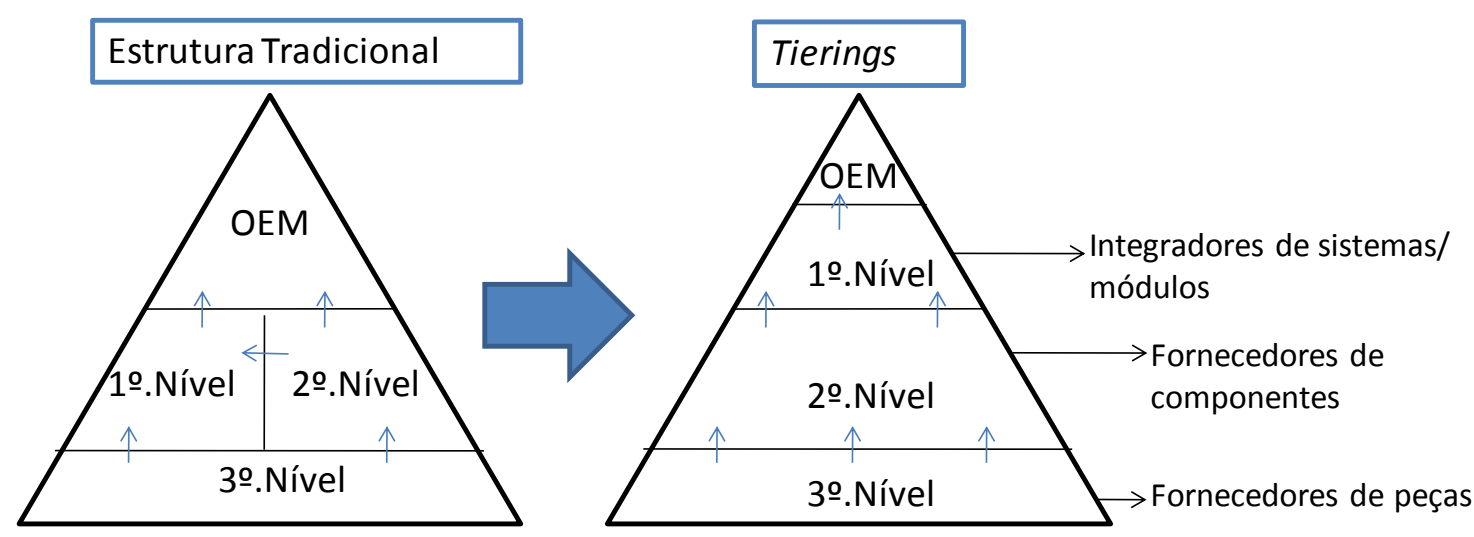

Figura 9 - Estrutura de fornecimento da cadeia de suprimentos automotiva Fonte: adaptado de Jürgens (2004)

\subsection{Síntese da Revisão Teórica}

A revisão teórica iniciou-se com uma revisão geral da literatura sobre estratégia e competição, com enfoque na gestão da cadeia de suprimentos e na tomada de decisão de make or buy. As subseções seguintes abordaram 0 desenvolvimento de produto com foco na tecnologia, inovação e definição sobre a 
arquitetura do produto (integral ou modular). Através do estudo foi possível verificar que os produtos modulares se relacionam fortemente com cadeias modulares. Nesta seção foi possível explorar a visão de Sturgeon (2002), com foco na padronização das interfaces e normatização, derrubando as formas de integração vertical. Langlois (2001) complementa o estudo justificando o porquê de as empresas estarem se desintegrando: aumento do volume de produção e da complexidade tecnológica. Malerba et al. (2008) e Brusoni (2005) discorrem sobre o acúmulo de capacitação e aprendizagem das empresas na forma modular e sobre os limites cognitivos da divisão do trabalho nessa forma. Por fim, Pavitt (2003) ressalta a importância de a empresa contratante ter a competência da integração.

O Quadro 8 sintetiza os principais temas e enfoques vistos na revisão teórica que serviu como modelo para a observação e análise do estudo de caso.

\begin{tabular}{|c|c|c|}
\hline Tema & Enfoque principal & Autores \\
\hline Estratégia e competição & Foco na core competence & $\begin{array}{l}\text { Prahald e Hamel (1990) } \\
\text { Fleury e Fleury (2003) }\end{array}$ \\
\hline $\begin{array}{l}\text { Gestão da Cadeia de } \\
\text { Suprimentos }\end{array}$ & $\begin{array}{l}\text { Eficiência operacional } \\
\text { Tomada de decisão make or buy: } \\
\text { análise econômica, de custo de } \\
\text { transação, estratégica e } \\
\text { multidimensional }\end{array}$ & $\begin{array}{l}\text { Slack et al. (2002) } \\
\text { Di Serio e Sampaio (2001) }\end{array}$ \\
\hline $\begin{array}{l}\text { Arquitetura de produto } \\
\text { modular }\end{array}$ & Enfoque no produto modular & $\begin{array}{l}\text { Baldwin; Clark (1997), } \\
\text { Dias (2003), } \\
\text { Salerno et al. (2008) }\end{array}$ \\
\hline Redes Modulares & $\begin{array}{l}\text { Diferenças entre estrutura } \\
\text { organizacional modular e vertical } \\
\text { Integração em redes } \\
\text { Mudanças constantes entre as formas } \\
\text { organizacionais (integração vertical } \\
\text { versus desintegração) }\end{array}$ & $\begin{array}{l}\text { Sturgeon (2002); Langlois } \\
\text { (2001); Malerba et al. } \\
\text { (2008), Brusoni (2005). } \\
\text { Pavitt (2003) } \\
\text { Fine (2000) }\end{array}$ \\
\hline $\begin{array}{l}\text { Gestão da Cadeia de } \\
\text { Fornecimento }\end{array}$ & $\begin{array}{l}\text { Relação com fornecedores (global } \\
\text { sourcing, follow sourcing, co-design, } \\
\text { parceria) } \\
\text { Alianças Estratégicas } \\
\text { Seleção de Fornecedores }\end{array}$ & $\begin{array}{l}\text { Salerno et al. (1998) e } \\
\text { Bastos (2006) } \\
\text { Tidd et al. (2001); Klotzle } \\
\text { (2002); Lorange e Roos } \\
\text { (1996) } \\
\text { Motwani et al. (1999); Faria } \\
\text { e Vanalle (2006); Lima } \\
\text { (2004) }\end{array}$ \\
\hline
\end{tabular}

Quadro 8 - Resumo Referencial

Fonte: Elaborado pela autora. 


\section{METODOLOGIA}

Esta dissertação foi baseada em um estudo de caso único na Empresa Brasileira de Aeronáutica S/A (Embraer) como objeto em estudo, tendo o processo de definição de parcerias para aviação executiva como unidade de análise.

Yin (2001, p. 27) define o estudo de caso como "a estratégia escolhida ao se examinarem acontecimentos contemporâneos, mas quando não se podem manipular comportamentos relevantes". Essa definição diferencia o estudo de caso da pesquisa ação, em que os membros do sistema que se está estudando participam ativamente no ciclo do processo, como explica Coughlan e Coghlan (2002), enquanto no estudo de caso os pesquisadores são apenas observadores. Yin (2001, p. 32) ainda complementa a descrição do estudo de caso como sendo "uma investigação empírica que investiga um fenômeno contemporâneo dentro de seu contexto da vida real, especialmente quando o limite entre o fenômeno e o contexto não está claramente definido".

Há vários desafios em conduzir um estudo de caso: tempo consumido, habilidade dos pesquisadores, cuidado ao generalizar as conclusões baseando-se em um número limitado de casos e a garantia do rigor na investigação (VOSS et al., 2002).

O estudo de caso é uma estratégia de pesquisa cujo foco é a compreensão das dinâmicas que estão presentes em um ambiente único.

Metodologicamente, a condução de um estudo de caso não pode ser considerada como tarefa trivial (MIGUEL, 2007), devido ao fato de os trabalhos estarem sujeitos a críticas pela sua limitação metodológica na escolha do caso, na análise dos dados e na geração de conclusões baseadas muitas vezes em evidências.

Para Yin (2001) existem três motivos que justificam um caso único: (i) quando se trata de um caso decisivo ao testar uma teoria, (ii) quando se trata de um caso raro ou extremo e, por fim, (iii) quando se trata de um caso revelador.

A pesquisa em questão se enquadra em todas as justificativas, pois as observações e impressões sobre o problema indicam a estratégia de parcerias com fornecedores adotada pela empresa como um caso único no país e no mundo, ao 
menos no segmento de complexidade e investimentos tão altos como o aeronáutico, e revelador no contexto mundial, chegando ao ponto de empresas gigantes do setor aeronáutico, como Boeing e Airbus, utilizarem formas de relacionamento com fornecedores introduzidas pela empresa pesquisada para readequar suas estratégias de produção.

"Para driblar a forte competição do mercado e reduzir custos, Boeing e Airbus estão seguindo o caminho da Embraer e terceirizando parte significativa de sua produção dentro de um modelo de parceria de riscos. A fabricante nacional foi pioneira em utilizar a chamada gestão de parceria de riscos, na década de 90" (BARBOSA, 2008).

Eisenhardt (1989) descreve vários aspectos da elaboração de teoria a partir de estudos de casos. A autora descreve o método empregado neste trabalho, o estudo de caso, como uma estratégia de pesquisa em que se concentram a compreensão da dinâmica presente em cenários únicos, combinando métodos de coletas de dados como documentos, entrevistas e observações, podendo a evidência ser quantitativa ou qualitativa, ou ambas. O estudo de caso pode ser utilizado para vários objetivos: fornecer descrição, avaliar teoria ou gerar teoria.

As técnicas utilizadas na presente pesquisa foram observação direta e pesquisa em dados secundários em revistas especializadas, artigos acadêmicos, websites vinculados à indústria aeronáutica e associações setoriais, e documentos da empresa. Além disso, foram conduzidas entrevistas semiestruturadas com empregados e ex-empregados da empresa envolvidos direta ou indiretamente na tomada de decisão no que se refere à estratégia na relação com os fornecedores. Devido às diferentes perspectivas, e para possibilitar a triangulação das respostas, para melhor controle metodológico (YIN, 2001; MIGUEL, 2007) foram escolhidos diversos entrevistados, ressaltando, entretanto, que não se manifestaram formalmente em nome da empresa; as opiniões eventualmente emitidas são pessoais, não da empresa.

Os questionários foram aplicados em duas etapas. A primeira etapa foi elaborada com o objetivo de identificar os aspectos gerais da relação com os fornecedores. Utilizou-se um questionário com questões abertas que constam no APÊNDICE A.

Foram aplicadas 6 entrevistas com foco na área de compras e estratégia de mercado, conforme o Quadro 9. 


\begin{tabular}{|l|l|l|}
\hline & \multicolumn{1}{|c|}{ Cargo } & \multicolumn{1}{c|}{ Área } \\
\hline 1 & Administrador de Contrato de Compras & Compras \\
\hline 2 & Administrador de Contrato de Compras & Compras \\
\hline 3 & Diretor de Vendas e ex-Gestor de Compras & Compras \\
\hline 4 & Gerente de Estratégia de Mercado & Estratégia de Mercado \\
\hline 5 & Supervisor da equipe de Compras & Compras \\
\hline 6 & Supervisor da equipe de compras (ex-empregado) & Compras \\
\hline
\end{tabular}

Quadro 9 - Perfil dos entrevistados na primeira etapa

Fonte: Elaborado pela autora.

Com base nessas entrevistas e nos estudos mais aprofundados dos documentos, foi elaborado um novo questionário que consta no APÊNDICE $B$, com perguntas mais específicas e abertas, de forma a identificar os aspectos estudados. Abaixo encontram-se as principais perguntas abordadas nesse questionário:

1) Como começa o processo de decisão de make or buy?

2) Quais as áreas envolvidas no processo de um novo projeto?

3) Como é a relação com parceiros e fornecedores?

4) Como se define a relação de parceiros e fornecedores em cada programa?

5) Qual a abrangência da parceria em termos de: tecnologia, desenvolvimento do produto e investimento?

6) Quais os principais fatores/critérios utilizados nas escolhas dos parceiros/fornecedores?

7) Houve mudança na estratégia da relação de "parceiro" para "fornecedor" ao longo dos programas? Por quê?

8) Como é feito o processo para estipular a quantidade de parceiros/fornecedores que terão em cada programa e o valor que cada um terá que investir na Embraer?

9) Como é feito o retorno de investimento do parceiro/fornecedor num esquema de risco? Como o parceiro/ fornecedor pode ser beneficiado com o after marketing?

10) A estratégia de fornecimento por subconjuntos inicialmente planejada para o programa 170 ainda é mantida? Por quê? Ela é aplicável aos programas novos?

11) Qual a tendência hoje para os novos produtos, em relação ao processo de fornecimento? Por exemplo, existe uma tendência na empresa para 
ter menos fornecedores e mais fabricação interna?

As perguntas 1 e 2 foram feitas para investigar o processo de decisão de make or buy e entender o processo de desenvolvimento do produto. As perguntas de 3 a 6 foram feitas para entender como é a gestão de relacionamento na área de compras com os critérios utilizados para definição de parceria e escolha de fornecedores. As perguntas de 7 a 9 foram feitas para investigar o caráter estratégico da relação e entender a engenharia financeira existente por trás das alianças estratégicas. As perguntas 10 e 11 estão relacionadas com a abordagem da teoria sobre modularidade e o comportamento da forma organizacional.

Foram aplicadas mais 8 entrevistas concentradas nas áreas de Gestão da Cadeia de Suprimentos, Engenharia, Controladoria, e na área de Planejamento Estratégico, como apresentado no Quadro 10.

\begin{tabular}{|l|l|l|}
\hline & \multicolumn{1}{|c|}{ Cargo } & \multicolumn{1}{c|}{ Área } \\
\hline 1 & Analista da Cadeia de Suprimentos & Gestão da Cadeia de Suprimentos \\
\hline 2 & Engenheiro de Desenvolvimento de Processo & Gestão da Cadeia de Suprimentos \\
\hline 3 & $\begin{array}{l}\text { Gerente de Planejamento Integrado do Centro de } \\
\text { Competência }\end{array}$ & Engenharia \\
\hline 4 & $\begin{array}{l}\text { Engenheiro de Desenvolvimento do Produto - Centro de } \\
\text { Estudos Conceituais }\end{array}$ & Engenharia \\
\hline 5 & $\begin{array}{l}\text { Analista de Controladoria - Área de Planejamento } \\
\text { Econômico }\end{array}$ & Controladoria \\
\hline 6 & Assessor de Planejamento Estratégico & Planejamento Estratégico \\
\hline 7 & Assessor de Planejamento Estratégico (ex-empregado) & Planejamento Estratégico \\
\hline 8 & Diretor de Planejamento Estratégico & Planejamento Estratégico \\
\hline
\end{tabular}

Quadro 10 - Perfil dos entrevistados na segunda etapa

Fonte: Elaborado pela autora.

Foram escolhidos empregados ligados diretamente ao processo e com poder de influência na tomada de decisão. Todos os 14 entrevistados apresentam em média mais de dez anos de empresa, com formação superior e algum tipo de especialização acadêmica na função.

Com relação à análise dos dados, o trabalho utilizou a abordagem dedutiva na fundamentação teórica, buscando conceitos que dessem sustentação ao assunto estudado. A abordagem indutiva foi utilizada na coleta dos dados e informações, bem como a análise dos dados e resultados, com o propósito de ampliar os 
conhecimentos captados pelo estudo. As anotações, assim como os dados secundários e as observações diretas, foram transcritos e transferidos para arquivos eletrônicos.

O processo de triangulação foi feito através do cruzamento das informações coletadas nas entrevistas com a análise documental, a observação direta e os fundamentos teóricos.

O Quadro 11 resume os principais pontos metodológicos da pesquisa.

\begin{tabular}{|l|l|}
\hline \multicolumn{1}{|c|}{ Abordagem } & \multicolumn{1}{c|}{ Estudo de Caso Único } \\
\hline Tema de Análise & $\begin{array}{l}\text { A estratégia na relação com os fornecedores na indústria aeronáutica } \\
\text { brasileira. }\end{array}$ \\
\hline Objeto de Análise & Embraer S/A. \\
\hline Coleta de Dados & $\begin{array}{l}\text { Entrevistas, análise documental, busca em fontes secundárias e } \\
\text { websites especializados. }\end{array}$ \\
\hline Análise dos Dados & $\begin{array}{l}\text { Interpretação dos dados qualitativos, abordagem dedutiva } \\
\text { (fundamentação teórica) e indutiva (coleta e análise dos dados). }\end{array}$ \\
\hline Qualidade e Validade & $\begin{array}{l}\text { Busca pela imparcialidade, diversas fontes de evidência (triangulação), } \\
\text { revisão das transcrições das entrevistas pelos entrevistados. }\end{array}$ \\
\hline Referencial teórico & $\begin{array}{l}\text { Gestão de Relacionamento em Suprimentos (SRM), Modularidade, } \\
\text { Procura e Seleção de Fornecedores, Desenvolvimento de Produto }\end{array}$ \\
\hline Tipologia dos dados & Qualitativos \\
\hline Contribuição Teórica & Refinamento da Teoria \\
\hline
\end{tabular}

Quadro 11 - Principais enfoques metodológicos desta pesquisa

Fonte: adaptado Miguel (2006).

Os resultados da pesquisa foram avaliados e analisados à luz da teoria descrita no referencial teórico. 


\section{ESTUDO DE CASO}

Esta seção detalha a empresa que é objeto deste estudo de caso - a Embraer. Apresenta inicialmente um breve histórico. Identifica os principais segmentos em que ela atua, dentre eles o mercado da Aviação Executiva dentro da Aviação Geral e o mercado de Defesa que a pesquisa contempla. Descreve a cadeia de suprimentos dentro da indústria aeronáutica para compreender os tipos de relacionamento existentes entre a empresa e seus fornecedores. Por fim, apresentam as famílias de aeronaves produzidas pela empresa e o relacionamento com seus fornecedores.

Na próxima seção serão discutidos e analisados os dados levantados no processo de pesquisa.

\subsection{Embraer}

A Embraer S/A atua na aviação há mais de 40 anos. Localizada no interior de São Paulo, na cidade de São José dos Campos, é uma das maiores empresas aeroespaciais do mundo.

A empresa foi criada em 1969 como uma estatal com a finalidade de produzir a aeronave Bandeirante em série. Em 1970, o Bandeirante começou a ser exportado para o mercado europeu e a empresa fez as suas primeiras parcerias com empresas aeronáuticas. Nos anos 1980, houve o desenvolvimento do modelo EMB 120, conhecido comercialmente como Brasília, do EMB 145, do programa AMX, do CBA 123 e do EMB 312 Tucano.

A empresa tem cerca de 16 mil empregados em todo o mundo, com escritórios, instalações industriais e oficinas de serviço ao cliente em cinco continentes, em países como Brasil, Estados Unidos, França, Portugal, China e Cingapura. Os resultados mostram mais de $600 \mathrm{E}$-jets entregues, 1.100 aeronaves da família ERJ145 produzidas, 170 jatos executivos Legacy 600 voando, 169 Super Tucanos vendidos e um projeto de US $\$ 1,3$ bilhões decorrente do lançamento do KC- 
390, em parceria com a Força Aérea Brasileira ( $F A B$ ). Tais fatos marcam em números os resultados da empresa e a tornam uma das maiores fabricantes mundiais do setor de aviação.

\begin{tabular}{|l|l|}
\hline \multicolumn{1}{|c|}{ Descrição } & \multicolumn{1}{c|}{ Valores } \\
\hline Número de empregados (Mar.2010) & 16.792 \\
\hline Pedidos firmes em carteira (Mar. 2010) & US\$16 bilhões \\
\hline Receita líquida (Mar. 2010) & $\mathrm{R} \$ 1.780$ milhões \\
\hline Lucro líquido (Mar. 2010) & $\mathrm{R} \$ 44$ milhões \\
\hline
\end{tabular}

Quadro 12 - Dados sobre a Embraer.

Fonte: Embraer (2010a).

Em 2009, a empresa teve uma receita líquida de $\mathrm{R} \$ 10,812$ milhões. Suas exportações totalizaram US\$4.053,3 milhões, o que a coloca como a quarta maior exportadora brasileira, com uma contribuição de $2,65 \%$ para o saldo da balança comercial brasileira. Ela atua em três grandes mercados: mercado de aviação comercial, de aviação executiva e de defesa, conforme Embraer (2009c).

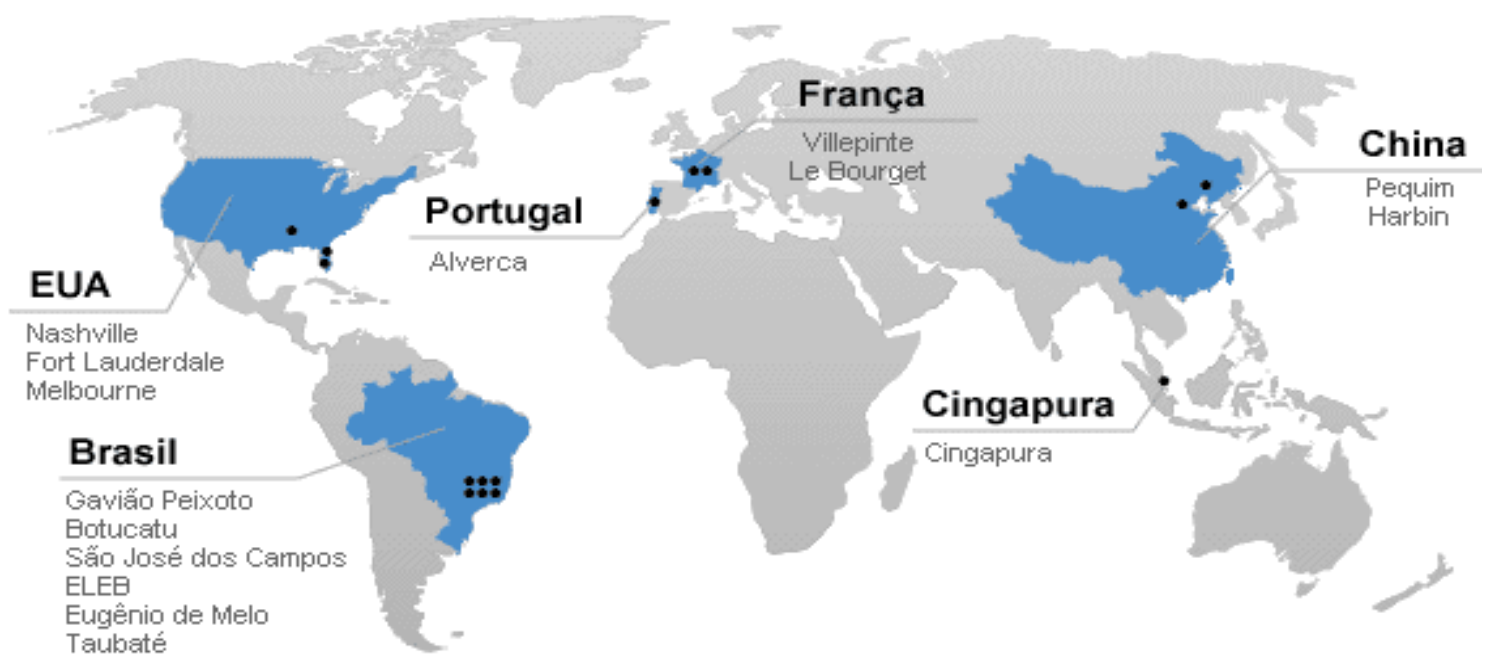

Figura 10 - Unidades e escritórios da Embraer no mundo

Fonte: Embraer (2010a).

\subsection{Surgimento da Empresa}

Por volta de 1940 ocorreu a fundação do Centro Tecnológico da Aeronáutica 
(CTA), atualmente o Comando Geral de Tecnologia Aeroespacial, com a aprovação do "Plano de Criação do CTA", em 16 de novembro de 1945, conhecido como "Plano Smith-Montenegro", por reunir as ideias do professor Richard H. Smith, Chefe do Departamento de Engenharia Aeronáutica do Instituto de Tecnologia de Massachusetts (MIT), nos Estados Unidos, e do Brigadeiro Casimiro Montenegro Filho, então chefe da Subdiretoria Técnica de Aeronáutica do Ministério da Aeronáutica. Ambos propuseram a criação da escola de engenharia aeronáutica que veio a se tornar o Instituto Tecnológico de Aeronáutica (ITA) e a criação de uma indústria aeronáutica para desenvolver aviões. O objetivo principal era o ITA fornecer massa crítica intelectual sobre a qual se apoiaria o CTA. Em 1953 foi criado o Instituto de Pesquisa e Desenvolvimento (IPD) do CTA para desenvolver projetos e experimentos no campo aeronáutico.

\subsubsection{Do Bandeirante ao Nascimento da Embraer}

O Ministério da Aeronáutica pediu ao CTA o estudo de viabilidade para a criação de uma linha de produção de aviões de transporte de passageiros. A prioridade era o transporte de pessoal e cargas da Força Aérea Brasileira (FAB). O programa denominado IPD-6504 foi aprovado pelo Ministro da Aeronáutica em junho de 1965, e o primeiro protótipo do Bandeirante voou em 22 de outubro de 1968, segundo Bandeirante (2009).

Em 19 de agosto de 1969 foi fundada a Embraer, criada como empresa de capital misto, controlada pela União e destinada à fabricação em série do novo bimotor turboélice EMB110 Bandeirante. O primeiro Diretor Superintendente da Embraer, o tenente-coronel e engenheiro Ozires Silva, foi um dos idealizadores do IPD-6504. Os contratos que deram base para a empresa foram com o Ministério da Aeronáutica. O primeiro previa a criação de 80 aviões Bandeirante e o segundo, 112 unidades do Xavante.

Na década de 1990 a empresa enfrentou grave crise financeira, retardando o desenvolvimento do EMB145 e cancelando o projeto CBA123 Vector. Em 07 de janeiro de 1994, após longo processo, a empresa foi privatizada e entrou em uma 
nova era, cuja estratégia estava baseada na premissa de que o domínio da integração de sistemas era mais crucial do que ter uma fatia expressiva do valor agregado ao avião sendo produzida no Brasil. Associando a isso às competências técnicas desenvolvidas em tecnologia aeronáutica, a empresa obteve independência e autonomia na tomada de decisão quanto à gestão do negócio, à concepção de projetos e à criação de oportunidades de mercado, conforme Cassiolato et al. (2002).

O Quadro 13 resume os eventos mais importantes que afetaram a história da Embraer. 


\begin{tabular}{|l|l|}
\hline Ano & \multicolumn{1}{|c|}{ Principais eventos } \\
\hline 1969 & Fundação da Embraer em 19 de agosto \\
\hline 1970 & $\begin{array}{l}\text { Ministério da Aeronáutica assina } \\
\text { contrato para 80 aviões Bandeirante }\end{array}$ \\
\hline 1971 & $\begin{array}{l}\text { Início da produção do Bandeirante } \\
\text { primeiro voo do Xavante }\end{array}$ \\
\hline 1972 & $\begin{array}{l}\text { Primeiro voo e certificação do } \\
\text { Bandeirante de série. }\end{array}$ \\
\hline 1973 & $\begin{array}{l}\text { Bandeirante opera na Transbrasil e na } \\
\text { Vasp }\end{array}$ \\
\hline 1975 & $\begin{array}{l}\text { Exportados os primeiros Bandeirante } \\
\text { para Força Aérea Uruguaia }\end{array}$ \\
\hline 1976 & EMB 121 Xingu faz voo inaugural \\
\hline 1977 & $\begin{array}{l}\text { Francesa Air Littoral importa o EMB 110 } \\
\text { Bandeirante }\end{array}$ \\
\hline 1978 & $\begin{array}{l}\text { A FAB contrata a Embraer para } \\
\text { desenvolver o EMB 312 Tucano }\end{array}$ \\
\hline 1979 & $\begin{array}{l}\text { Estabelecida a Embraer Aircraft } \\
\text { Company nos Estados Unidos }\end{array}$ \\
\hline 1980 & Primeiro voo do EMB 312 Tucano \\
\hline 1981 & $\begin{array}{l}\text { Desenvolvimento e fabricação do AMX } \\
\text { junto com as empresas italianas Aeritalia } \\
\text { (hoje Alenia) e Aermacchi }\end{array}$ \\
\hline 1983 & $\begin{array}{l}\text { AMX e EMB 120 Brasília voam pela } \\
\text { primeira vez. Estabelecida a Embraer } \\
\text { Aviation International (EAI), na França }\end{array}$ \\
\hline 1988 & Início do desenvolvimento do CBA 123 \\
\hline 1989 & $\begin{array}{l}\text { Começa o projeto do jato EMB 145, } \\
\text { futuro ERJ 145 }\end{array}$ \\
\hline 1990 & A aeronave CBA 123 faz primeiro voo \\
\hline 1991 & Programa EMB 145 é relançado \\
\hline
\end{tabular}

\begin{tabular}{|c|c|}
\hline Ano & Principais eventos \\
\hline 1992 & $\begin{array}{l}\text { Início do processo de privatização da } \\
\text { Embraer }\end{array}$ \\
\hline 1993 & $\begin{array}{l}\text { Embraer estabelece acordos para o } \\
\text { desenvolvimento do EMB } 145\end{array}$ \\
\hline 1994 & Embraer é privatizada \\
\hline 1995 & Primeiro voo do EMB 145 \\
\hline 1996 & $\begin{array}{l}\text { Primeiro ERJ } 145 \text { para a Continental } \\
\text { Express }\end{array}$ \\
\hline 1997 & $\begin{array}{l}\text { Desenvolvimento das aeronaves de } \\
\text { Inteligência,Vigilância e Reconhecimento } \\
\text { (ISR) para o SIVAM do Governo Brasileiro }\end{array}$ \\
\hline 1998 & $\begin{array}{l}\text { EMB } 145 \text { passa a adotar a sigla ERJ } 145 \\
\text { (de "Embraer Regional Jet") }\end{array}$ \\
\hline 1999 & $\begin{array}{l}\text { Desenvolvimento da família EMBRAER } \\
\text { 170/190. Super Tucano faz voo inaugural. }\end{array}$ \\
\hline 2000 & Lançado o Programa Legacy \\
\hline 2001 & EMBRAER 170 é apresentado \\
\hline 2003 & $\begin{array}{l}\text { ERJ } 145 \text { é produzido na Harbin Embraer } \\
\text { Aircraft Industry (HEAl), na China }\end{array}$ \\
\hline 2004 & $\begin{array}{l}\text { EMBRAER } 170 \text { entra em operação } \\
\text { comercial na Europa e nos EUA }\end{array}$ \\
\hline 2005 & $\begin{array}{l}\text { Lançamento do jato executivo Phenom } 100 \\
\text { e Phenom } 300\end{array}$ \\
\hline 2006 & $\begin{array}{l}\text { Lançamento do jato executivo Lineage } \\
1000\end{array}$ \\
\hline 2007 & $\begin{array}{l}1000 \text { aeronaves ERJ } 145 \text { produzidas. } \\
\text { Primeiro voo do Phenom } 100\end{array}$ \\
\hline 2008 & $\begin{array}{l}\text { Primeiro voo do Phenom 300. Certificação } \\
\text { do Phenom } 100 \text { e do Lineage } 1000\end{array}$ \\
\hline 2009 & $\begin{array}{l}\text { Assinado o contrato para o lançamento do } \\
\text { programa KC-390 }\end{array}$ \\
\hline
\end{tabular}

Quadro 13 - Principais eventos da história da Embraer

Fonte: Bandeirante (2009).

A empresa embarcou em profunda transformação cultural e empresarial, impulsionada pelo jato regional ERJ145. Nos anos seguintes, com a entrada no mercado de aviação executiva e início de operação da família de jatos comerciais Embraer 170/190, a empresa expandiu ainda mais sua atuação no mercado. A Figura 11 mostra o contínuo aumento da quantidade de aeronaves entregues pela Embraer nos últimos anos. 


\begin{tabular}{|l|l|l|l|}
\hline 2006 & 2007 & 2008 & 2009 \\
\hline
\end{tabular}

\begin{tabular}{|l|c|c|c|c|}
\hline Aviação Comercial & 98 & 130 & 162 & 122 \\
\hline ERJ 135 & 0 & 0 & 0 & 0 \\
\hline ERJ 140 & 0 & 0 & 0 & 0 \\
\hline ERJ 145 & 12 & 7 & 6 & 7 \\
\hline EM BRAER 170 & 32 & 11 & 9 & 22 \\
\hline EM BRAER 175 & 11 & 34 & 55 & 11 \\
\hline EM BRAER 190 & 40 & 68 & 78 & 62 \\
\hline EM BRAER 195 & 3 & 10 & 14 & 20 \\
\hline Aviação Executiva & 27 & 35 & 36 & 115 \\
\hline Phenom 100 & 0 & 0 & 2 & 93 \\
\hline Phenom 300 & 0 & 0 & 0 & 1 \\
\hline Legacy 600 & 26 & 35 & 33 & 18 \\
\hline Legacy Shuttle & 1 & 0 & 0 & 0 \\
\hline EM BRAER 175 & 0 & 0 & 1 & 0 \\
\hline Lineage1000 & 0 & 0 & 0 & 3 \\
\hline Defesa & 5 & 4 & 6 & 7 \\
\hline Legacy600 & 0 & 1 & 3 & 0 \\
\hline EMB 135/145 & 0 & 1 & 3 & 1 \\
\hline EM BRAER 170 & 4 & 0 & 0 & 0 \\
\hline EM BRAER 190 & 1 & 2 & 0 & 2 \\
\hline Phenom 100 & 0 & 0 & 0 & 4 \\
\hline Total & 130 & 169 & 204 & 244 \\
\hline
\end{tabular}

Figura 11 - Total de aeronaves entregues nos últimos anos pela Embraer.

Fonte: Demonstrações Financeiras Padronizadas, Embraer 2009c.

\subsection{Aviação Executiva}

Segundo a International Civil Aviation Organization ${ }^{2}$ (ICAO), as operações da aviação civil são divididas em três categorias: transporte aéreo comercial, serviços aéreos especializados e aviação geral. A definição de Aviação Geral é feita por exclusão, ou seja, é aquela que não envolve o transporte aéreo comercial, nem os serviços aéreos especializados (transporte aéreo em atividades relacionadas à agricultura, aos negócios, à fotografia, inspeção, vigilância, busca e ao salvamento,

2 Organização da Aviação Civil Internacional. 
quer seja visando à exploração comercial ou beneficio próprio). (SANTOS, 2003; MENEZES, 2004).

Segundo a National Business Aviation Association ${ }^{3}$ (NBAA), a Aviação Geral inclui todas as aeronaves que não voam pelas linhas aéreas ou pelos militares. $A$ Aviação Executiva é um segmento da Aviação Geral, segundo a definição da ICAO e da NBAA, constituído por indivíduos e empresas que utilizam as aeronaves como ferramentas na condução de seus negócios (MENEZES, 2004).

A aviação executiva é um dos principais nichos perseguidos pela Embraer. Em 2006 as vendas da empresa brasileira superaram tanto as da Boeing quanto as da Airbus - US $\$ 637$ milhões, ante os US $\$ 592$ milhões da americana e os US $\$ 500$ milhões da europeia, segundo Miranda (2007).

A figura 12 traz os produtos da Embraer no segmento da aviação executiva e seus principais produtos concorrentes:

3 Associação da Aviação Executiva Nacional. 


\begin{tabular}{|c|c|c|}
\hline \multirow{4}{*}{ Phenom 300} & Produtos Concorrentes & Fabricante \\
\hline & $\mathrm{CJ} 2+, \mathrm{CJ} 3, \mathrm{CJ} 4$ & Cessna \\
\hline & Premier IA, Hawker 400XP & Hawker Beechcraft \\
\hline & Lear 40XR & Bombardier \\
\hline \multirow{4}{*}{ Phenom 100} & Produtos Concorrentes & Fabricante \\
\hline & Mustang, CJ1+ & Cessna \\
\hline & Eclipse & Eclipse Aerospace \\
\hline & Adam 700 & Adam Aircraft Industries \\
\hline \multirow{6}{*}{ Legacy 600} & Produtos Concorrentes & Fabricante \\
\hline & Hawker 4000 & Hawker Beechcraft \\
\hline & Challenger 300 , Challenger 850 , Challenger 605 & Bombardier \\
\hline & Citation X, Citation Columbus & Cessna \\
\hline & G200, G350, G450,G250 & Gulfstream \\
\hline & Falcon 2000DX,Falcon 2000EX, Falcon 2000LX,Falcon 900DX & Dassault Falcon \\
\hline \multirow{7}{*}{ Legacy 650} & Produtos Concorrentes & Fabricante \\
\hline & Challenger 300 , Challenger 605 , Challenger 850 & Bombardier \\
\hline & Hawker 4000 & Hawker Beechcraft \\
\hline & Citation $\mathrm{X}$ & Cessna \\
\hline & G200,G250,G350,G450 & Gulfstream \\
\hline & Legacy 600 & Embraer \\
\hline & Falcon 2000DX,Falcon 2000EX, Falcon 2000LX,Falcon 900DX & Dassault Falcon \\
\hline \multirow{5}{*}{ Legacy 500} & Produtos Concorrentes & Fabricante \\
\hline & $\mathrm{G} 150$ & Gulfstream \\
\hline & Hawker 900XP, Hawker 4000 & Hawker Beechcraft \\
\hline & Sovereign & Cessna \\
\hline & Learjet 85, Challenger 300 & Bombardier \\
\hline \multirow{5}{*}{ Legacy 450} & Produtos Concorrentes & Fabricante \\
\hline & Lear 45XR, Learjet 60XR & Bombardier \\
\hline & Citation XLS+ & Cessna \\
\hline & Hawker 750 & Hawker Beechcraft \\
\hline & G150 & Gulfstream \\
\hline \multirow{6}{*}{ Lineage 1000} & Produtos Concorrentes & Fabricante \\
\hline & A 318 Elite, ACJ & Airbus \\
\hline & BBJ 1 & Boeing \\
\hline & Global XRS, Global 5000 & Bombardier \\
\hline & Gulfstream 550, Gulfstream 450 & Gulfstream \\
\hline & Falcon 7x, Falcon 900EX & Dassault Falcon \\
\hline
\end{tabular}

Figura 12 - Produtos da Aviação Executiva da Embraer e seus concorrentes Fonte: Embraer,2010c 


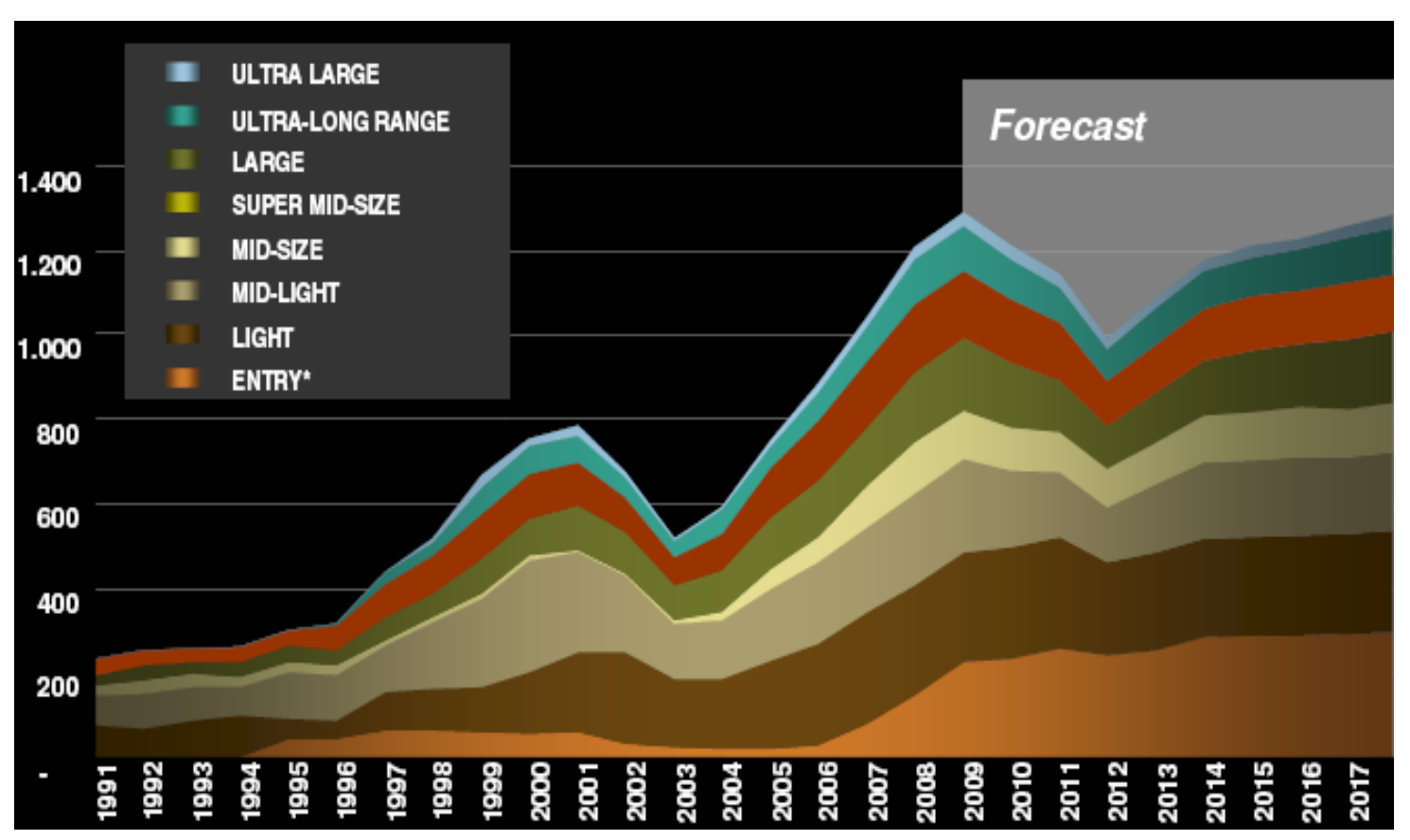

Figura 13 - Histórico e previsão de entrega de jatos executivos Fonte: Embraer (2008b).

O mercado de aviação executiva, estimado pela Embraer (2009c), terá uma demanda mundial de 10.000 jatos executivos para 2010-2019, número que poderá gerar negócios de cerca de US $\$ 190$ bilhões em entregas de novas aeronaves. Desde 2006, a indústria tem registrado consecutivos recordes de entregas, mas estima-se uma desaceleração devido ao atual período de crise econômica, com um ajuste para o período 2009-2012. No longo prazo, porém, a tendência de crescimento da demanda deve ser mantida em função da retomada do crescimento econômico, ainda que em níveis mais conservadores (Figura 13).

Os resultados de crescimento da ordem de 30\% nas entregas de 2009 (conforme Figura 14) fizeram com que a empresa conseguisse 14\% do mercado em 2009 (EMBRAER, 2010 b). 


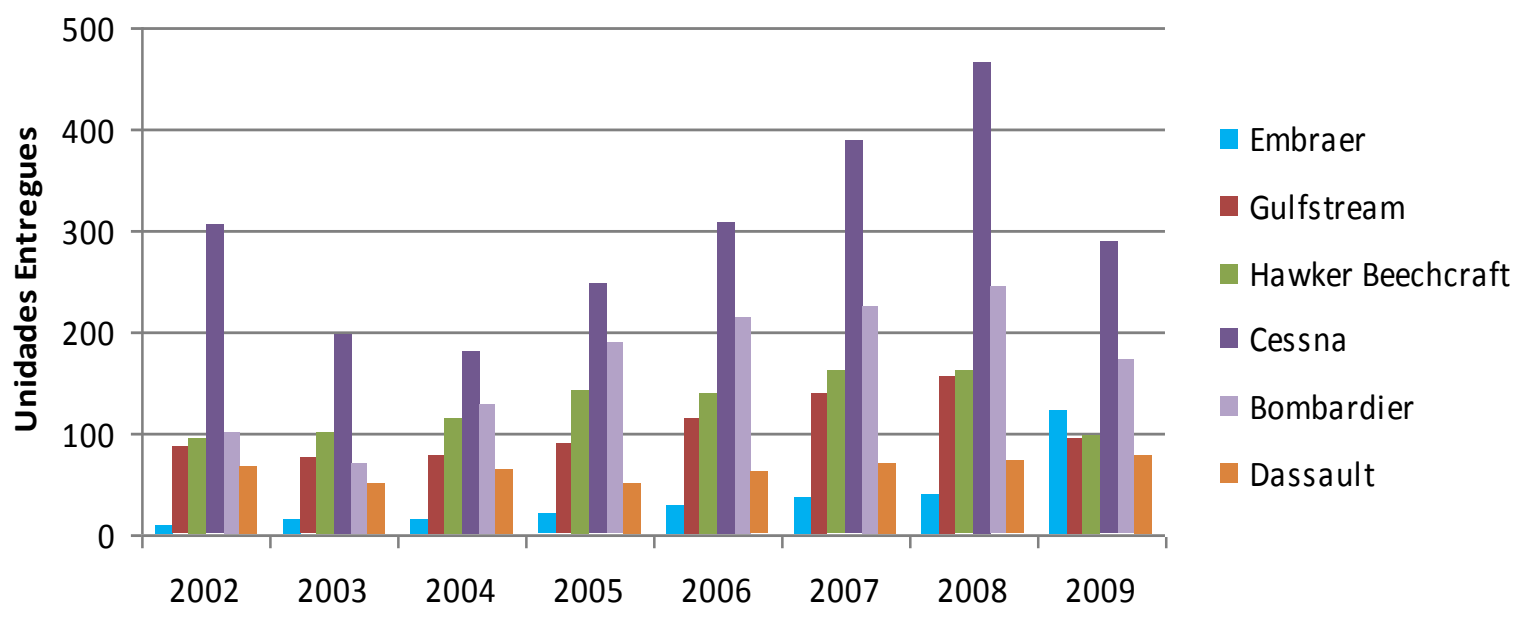

Figura 14 - Histórico de entregas de jatos executivos Fonte: GAMA (2010).

A empresa em estudo destacou-se por suas opções estratégicas de desenvolvimento e produção compartilhadas com fornecedores para redução de riscos. A Figura 15 apresenta o crescimento da participação da Embraer no mercado da Aviação Executiva de 2004 a 2009, e em 2009 aparece o maior percentual da empresa atingido até o momento: em torno de $14 \%$.

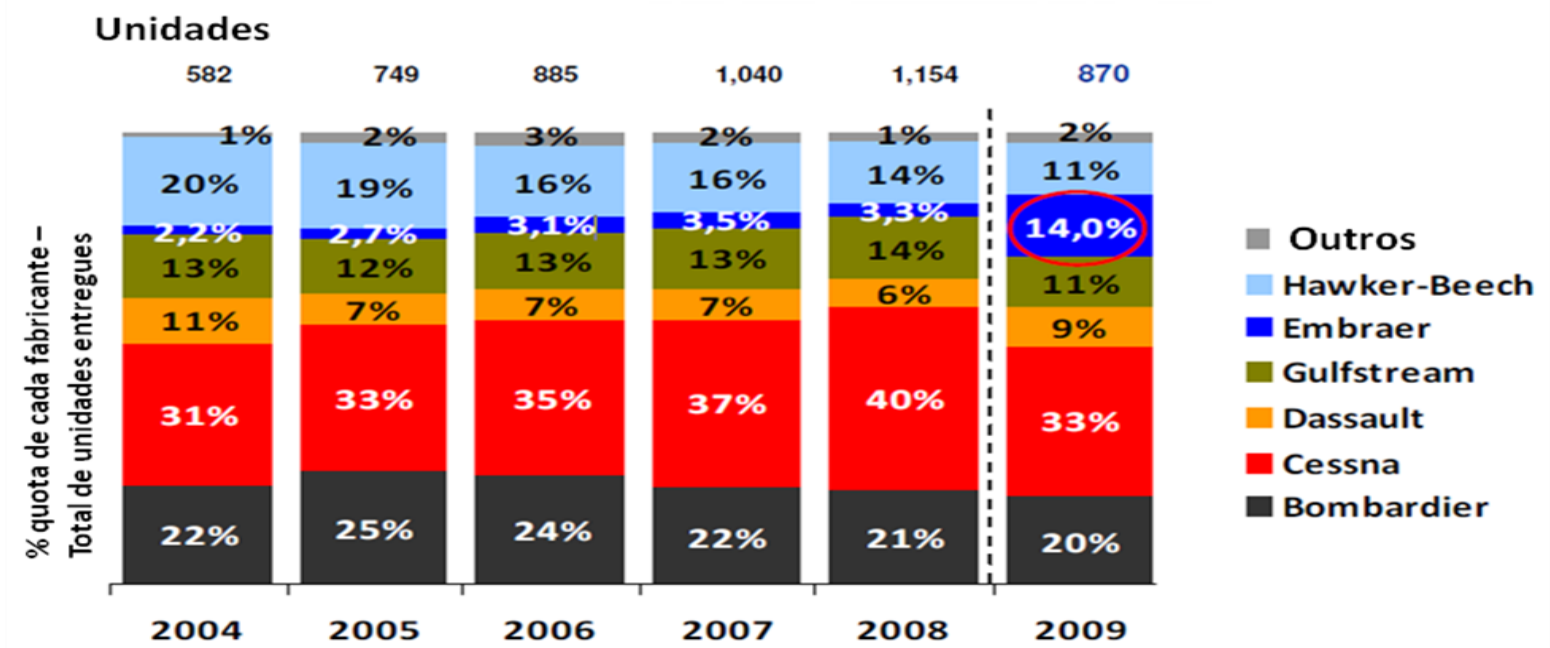

Figura 15 - Percentual de participação da Embraer na aviação executiva Fonte: Embraer (2010b). 
Para conseguir esses resultados, a empresa direciona suas atividades para atuar como integradora de sistemas, levando a um processo de desintegração vertical, ou seja: a transferência de atividades de manufatura aos fornecedores, com o compartilhamento de riscos, incentivos e benefícios (BASTOS, 2006). Esses fornecedores são considerados parceiros de risco e são aqueles que assumem os riscos financeiros na fase de desenvolvimento dos projetos.

Para compreender as denominações de parceiros de risco e fornecedores é importante localizar as empresas dentro da cadeia de suprimentos na indústria aeronáutica. A seguir, uma breve descrição da cadeia de suprimentos.

\subsection{A Cadeia de Suprimentos Aeronáutica}

As atividades da indústria aeronáutica dependem de peças e partes provenientes de diversos tipos de empresas, estando estas largamente dispersas em termos de localização, ao mesmo tempo em que o mercado consumidor não é limitado geograficamente (NIOSI; ZHEGU, 2005).

A cadeia de suprimentos da indústria aeronáutica é organizada de forma hierárquica e estratificada, como apresentado na Figura 16, de acordo com as tecnologias fornecidas e as atividades executadas pelos fabricantes, sendo liderada pelas empresas montadoras de aeronaves. À medida que se sobe na cadeia de suprimentos, aumenta a integração tecnológica e a especialização em projeto e desenvolvimento de produto. Por outro lado, ao descer na cadeia, cresce a especialização em tecnologia e processos de produção (BASTOS, 2006). 


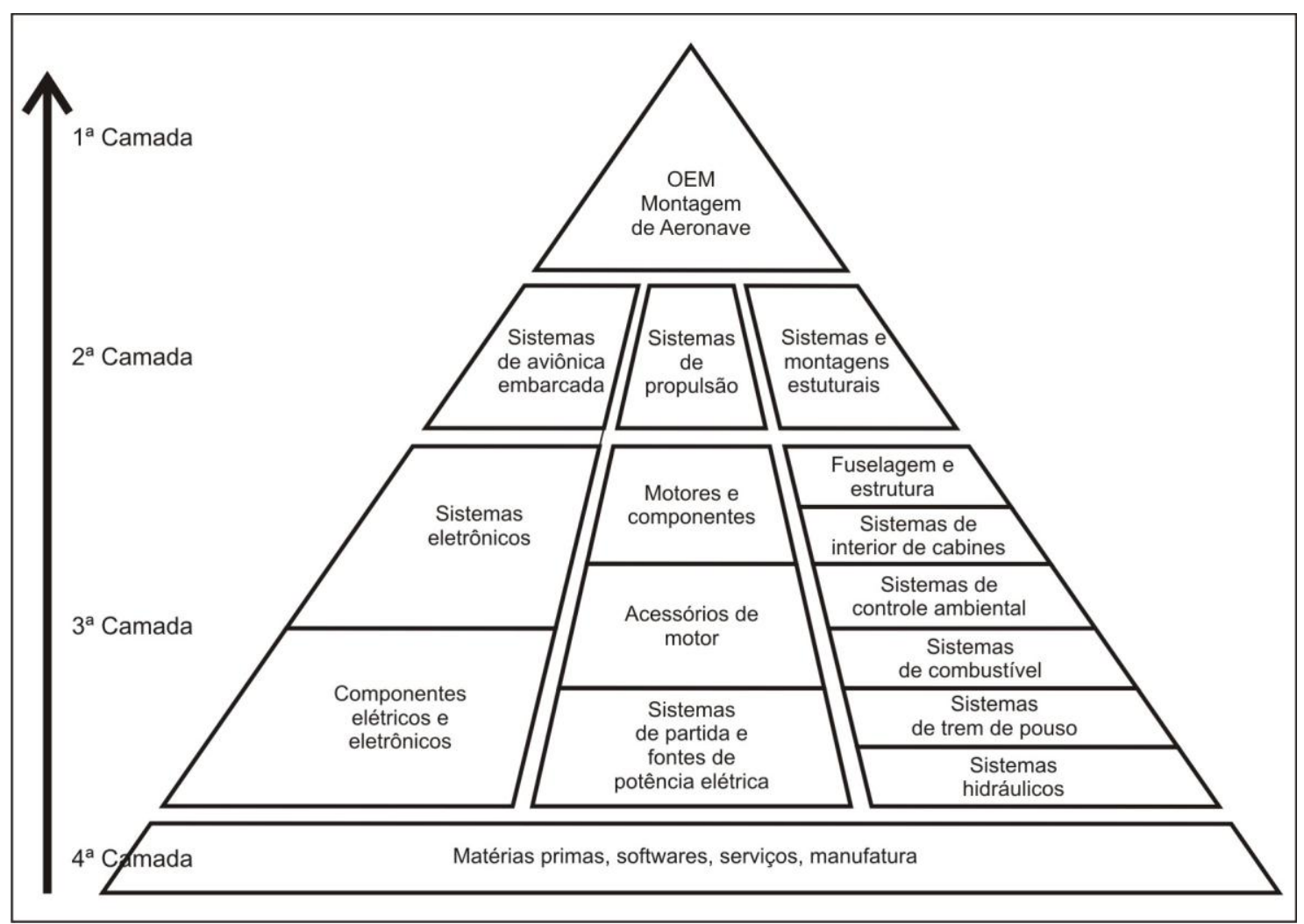

Figura 16 - Estrutura da cadeia de suprimentos aeronáutica Fontes: Adaptado de Niosi; Zhegu (2005); AECMA (2004).

No topo da pirâmide, conforme ilustrado na Figura 16, encontra-se a primeira camada, que se refere às montadoras de aeronaves (Original Equipment Manufacturer - OEMs), tais como Boeing, Airbus e Embraer, que lideram a cadeia. Essas empresas são as responsáveis pelo projeto e desenvolvimento do produto, prospecção de mercados, compra de submontagens da segunda camada e manufatura final do produto.

$\mathrm{Na}$ segunda camada estão os fornecedores que fazem grandes conjuntos: os fabricantes de sistemas de propulsão (p. ex.: GE, Pratt \& Whitney ou RollsRoyce); os produtores de aviônica embarcada (como Honeywell, Rockwell Collins ou Sextant Avionique); os sistemas e montagens de estruturas metálicas e submontagens (p. ex.: Latécoére, Liebherr ou Messier-Dowty).

De acordo com Giunta (1999), nesta camada estão os fornecedores preferenciais, para os quais as montadoras de aeronaves estão delegando parte da tarefa de integração dos componentes através da compra de sistemas completos. Esses fornecedores mantêm um relacionamento privilegiado com a montadora, com a qual partilham os riscos financeiros e industriais do projeto (parceiros de risco).

$\mathrm{Na}$ terceira camada encontram-se os fornecedores de sistemas eletrônicos, 
hidráulicos, elétricos e pneumáticos (como Parker, Hamilton ou Goodrich), sendo cada segmento dominado por um pequeno número de empresas. $O$ relacionamento é realizado com as empresas da segunda camada e indiretamente com a empresa montadora (parceiros).

A quarta camada é formada por uma gama maior de pequenos e médios fabricantes de componentes e peças, e por fornecedores de matéria prima para as demais camadas (como Alcoa, Otto Fuchs), que não atuam exclusivamente no setor aeronáutico, mas também em diversas outras indústrias (fornecedores).

Detalhada a cadeia de suprimentos dentro da indústria aeronáutica, foram levantadas as famílias de produtos da empresa em estudo e suas estruturas de fornecedores.

\subsection{Famílias de produtos}

A adoção do conceito de "família de aviões", que significa o desenvolvimento de versões a partir de um modelo básico, de forma similar ao que na indústria automobilística é conhecido como plataforma, permite à empresa ampliar a faixa de atuação do produto no mercado, com vantagens e benefícios tanto para os clientes - oferecendo menores custos de infraestrutura e manutenção da frota, comunalidade da tripulação e treinamento padronizado para pilotos e técnicos quanto para a empresa, com menores custos, mais rapidez no desenvolvimento de produto e redução dos ciclos de produção. Os Quadros 14 e 15 contemplam as principais famílias, plataformas e produtos da Embraer para aviação comercial e executiva. 


\begin{tabular}{|c|c|c|c|}
\hline Família & Plataforma & Modelo & Descrição \\
\hline \multirow{4}{*}{145} & \multirow{4}{*}{ ERJ 145} & ERJ 145 & $\begin{array}{l}\text { Primeiro membro lançado da família de jatos regionais, com } \\
50 \text { assentos e um alcance de } 2.871 \mathrm{~km} \text {, a uma velocidade } \\
\text { máxima de } 0,78 \text { mach. }\end{array}$ \\
\hline & & $\begin{array}{l}\text { ERJ } 145 \\
\text { XR }\end{array}$ & $\begin{array}{l}\text { Versão de longo alcance da aeronave de } 50 \text { assentos } \\
\text { (3.704km), atingindo velocidade máxima de 0,80mach. }\end{array}$ \\
\hline & & ERJ 140 & $\begin{array}{l}\text { Jato regional para } 44 \text { passageiros, seguindo o conceito de } \\
\text { "família } 145 \text { ". Alcance de } 3.056 \mathrm{~km} \text { com a mesma velocidade } \\
\text { do ERJ } 135 .\end{array}$ \\
\hline & & ERJ 135 & $\begin{array}{l}\text { Jato regional para } 37 \text { passageiros, versão compacta do } \\
\text { ERJ145. Atinge velocidade máxima de } 0,78 \text { mach e alcance } \\
\text { de } 3.241 \mathrm{~km} \text {. }\end{array}$ \\
\hline \multirow{4}{*}{ E-Jets } & \multirow{2}{*}{ EMB 170} & EMB 170 & $\begin{array}{l}\text { Jato regional para } 70 \text { a } 78 \text { passageiros, podendo atingir } \\
\text { velocidade máxima de } 0,82 \text { mach com um alcance de } \\
3.704 \mathrm{~km} \text {, desenvolvido com tecnologia de última geração. }\end{array}$ \\
\hline & & EMB 175 & $\begin{array}{l}\text { Segundo componente da "família } 170 \text { ", cobrindo a faixa de } \\
78 \text { a } 86 \text { assentos, com a mesma velocidade e um alcance } \\
\text { de } 3.334 \mathrm{~km} \text {. }\end{array}$ \\
\hline & \multirow[b]{2}{*}{ EMB 190} & EMB 190 & $\begin{array}{l}\text { Jato regional para } 98 \text { a } 106 \text { passageiros, com alcance de } \\
4.260 \mathrm{~km} \text { a uma velocidade máxima de 0,82mach. }\end{array}$ \\
\hline & & EMB 195 & $\begin{array}{l}\text { Maior membro da "família" de jatos regionais, com } 108 \text { a } \\
118 \text { assentos e alcance de } 3.889 \mathrm{~km} \text { a uma velocidade de } \\
0,82 \text { mach. }\end{array}$ \\
\hline
\end{tabular}

Quadro 14 - Principais produtos aeronáuticos da aviação comercial da Embraer Fonte: Adaptado de Bastos (2006).

\begin{tabular}{|c|c|c|c|}
\hline Família & Plataforma & Modelo & Descrição \\
\hline \multirow{2}{*}{$\begin{array}{l}\text { Derivado } \\
\text { da } 145\end{array}$} & \multirow{2}{*}{ ERJ 135} & Legacy 600 & $\begin{array}{l}\text { Jato executivo desenvolvido com base na plataforma do } \\
\text { ERJ } 135 \text { para até } 16 \text { passageiros, com variada opção de } \\
\text { interior customizado. }\end{array}$ \\
\hline & & $\begin{array}{l}\text { Legacy } \\
\text { Shuttle }\end{array}$ & $\begin{array}{l}\text { Derivação do Legacy } 600 \text { para até } 19 \text { passageiros, } \\
\text { interior mais padronizado e com versatilidade para } \\
\text { estender até } 37 \text { assentos. }\end{array}$ \\
\hline \multirow{2}{*}{ Phenom } & \multirow{2}{*}{$\begin{array}{l}\text { Phenom } \\
100\end{array}$} & Phenom 100 & $\begin{array}{l}\text { Família de jatos executivos do segmento "very light" com } \\
\text { capacidade de até } 5 \text { passageiros. }\end{array}$ \\
\hline & & Phenom 300 & $\begin{array}{l}\text { Família de jatos executivo do segmento "light" com } \\
\text { capacidade de até } 10 \text { ocupantes. }\end{array}$ \\
\hline $\begin{array}{l}\text { Derivado } \\
\text { E-Jets }\end{array}$ & EMB 190 & Lineage 1000 & $\begin{array}{l}\text { Jato executivo do segmento "ultra-large" para até } 19 \\
\text { passageiros e com diversas opções de configuração de } \\
\text { interior, em desenvolvimento a partir da plataforma EMB } \\
190 .\end{array}$ \\
\hline \multirow{2}{*}{$\begin{array}{l}\text { Jatos } \\
\text { Médios }\end{array}$} & \multirow{2}{*}{ Legacy 500} & Legacy 500 & $\begin{array}{l}\text { Jato executivo classificado dentro do segmento "midlight" } \\
\text { (MLJ) alcance de } 4.260 \mathrm{~km} \text { ( } 2.300 \text { milhas náuticas). }\end{array}$ \\
\hline & & Legacy 450 & $\begin{array}{l}\text { Jato executivo classificado dentro do segmento "midsize" } \\
\text { (MSJ) alcance de } 5.560 \mathrm{~km} \text { ( } 3.000 \text { milhas náuticas). }\end{array}$ \\
\hline
\end{tabular}

Quadro 15 - Principais produtos aeronáuticos da aviação executiva da Embraer

Fonte: Adaptado de Bastos (2006); EMBRAER (2008). 


\subsubsection{Família 145}

No início dos anos 1990, a empresa relança o projeto EMB 145 como família ERJ 145 e estabelece acordo de parceria de risco com quatro parceiros: Gamesa, multinacional espanhola, fornecendo as asas e as naceles dos motores desses aviões; C\&D, multinacional americana, fornecendo os interiores das cabines, poltronas, painéis de serviços dos passageiros, revestimentos internos das laterais e do teto, divisórias para bagagem de mão, sistema de iluminação interna e porta da cabine de pilotagem; Empresa Nacional de Aeronáutica do Chile (ENAER), multinacional chilena, produzindo estruturas aeronáuticas que formam a empenagem dos aviões (deriva e leme); e Socièté Nationale de Construction Aerospatiale (SONACA), multinacional belga, produzindo fuselagem dos aviões e fornecendo suporte à produção.

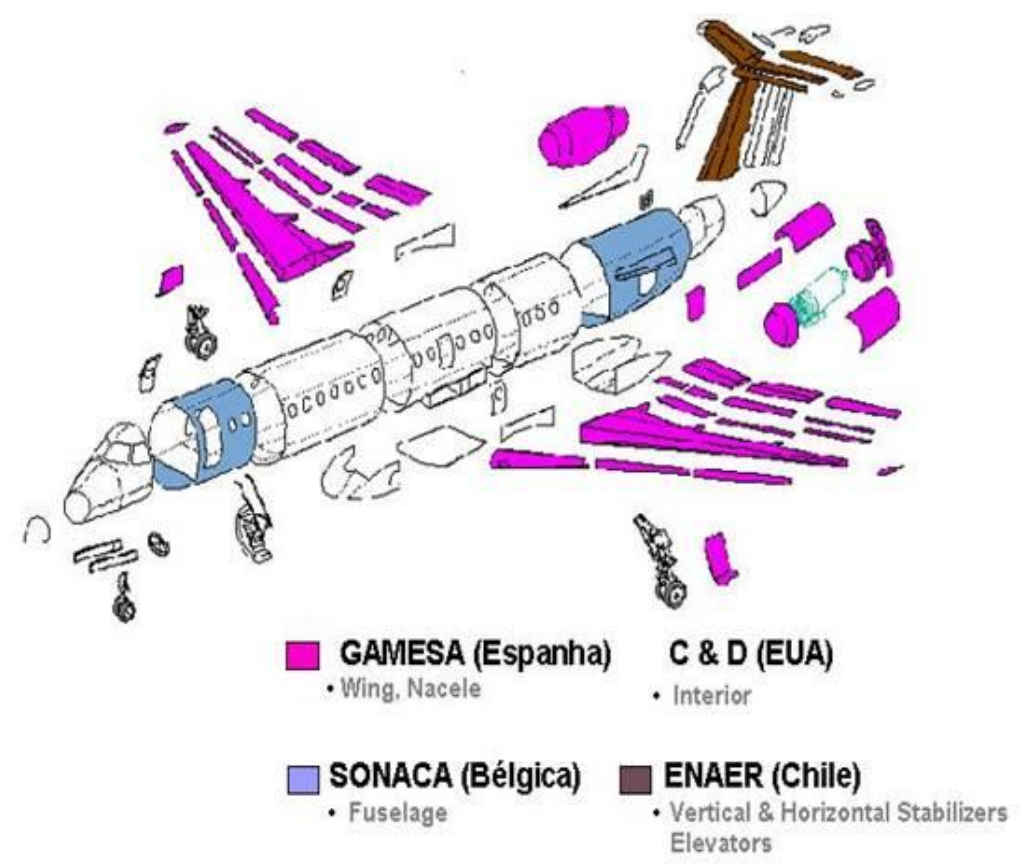

Figura 17 - Família 145 com 4 parceiros de risco e 350 Fornecedores Fonte: Embraer (2008b).

O projeto também contou com a participação de mais de 350 fornecedores, dentre eles os fornecedores dos principais componentes, como: Rolls-Royce, Honeywell, TRW Lucas, Goodrich, Liebherr, Hamilton Sundstrand, Parker Aerospace, Thales, Sierracin e EATON, conforme apresentado na Figura 17. O ERJ 145 entrou em operação em 1997, para atender o mercado de aviação regional com 
uma aeronave rápida, de baixo custo e econômica. A Embraer ofereceu ao mercado o ERJ 135, em 1999, e o ERJ 140, em 2001.

Um aspecto de extrema importância para essa família é o fator de comunalidade entre as aeronaves. Essa comunalidade se torna um grande diferencial no mercado, pois reduz o número de peças de reposição, permite a utilização dos mesmos equipamentos de suporte em solo e favorece a padronização de treinamento e manutenção da frota (PEREIRA, 2002).

\subsubsection{Família E-Jets}

No final dos anos 1990, lançou a família E-Jets composta por quatro modelos: Embraer 170, Embraer 175, Embraer 190 e Embraer 195, com capacidade de 70 a 118 lugares. O Programa ERJ 170/190 foi concebido sob a liderança da empresa e contou com o apoio de um grupo de 16 parceiros de risco. Esses parceiros e mais um grupo de 22 fornecedores dos principais componentes foram responsáveis pelo projeto e fornecimento dos segmentos estruturais e dos sistemas de controle da aeronave, conforme Figura 18 (PEREIRA, 2002).

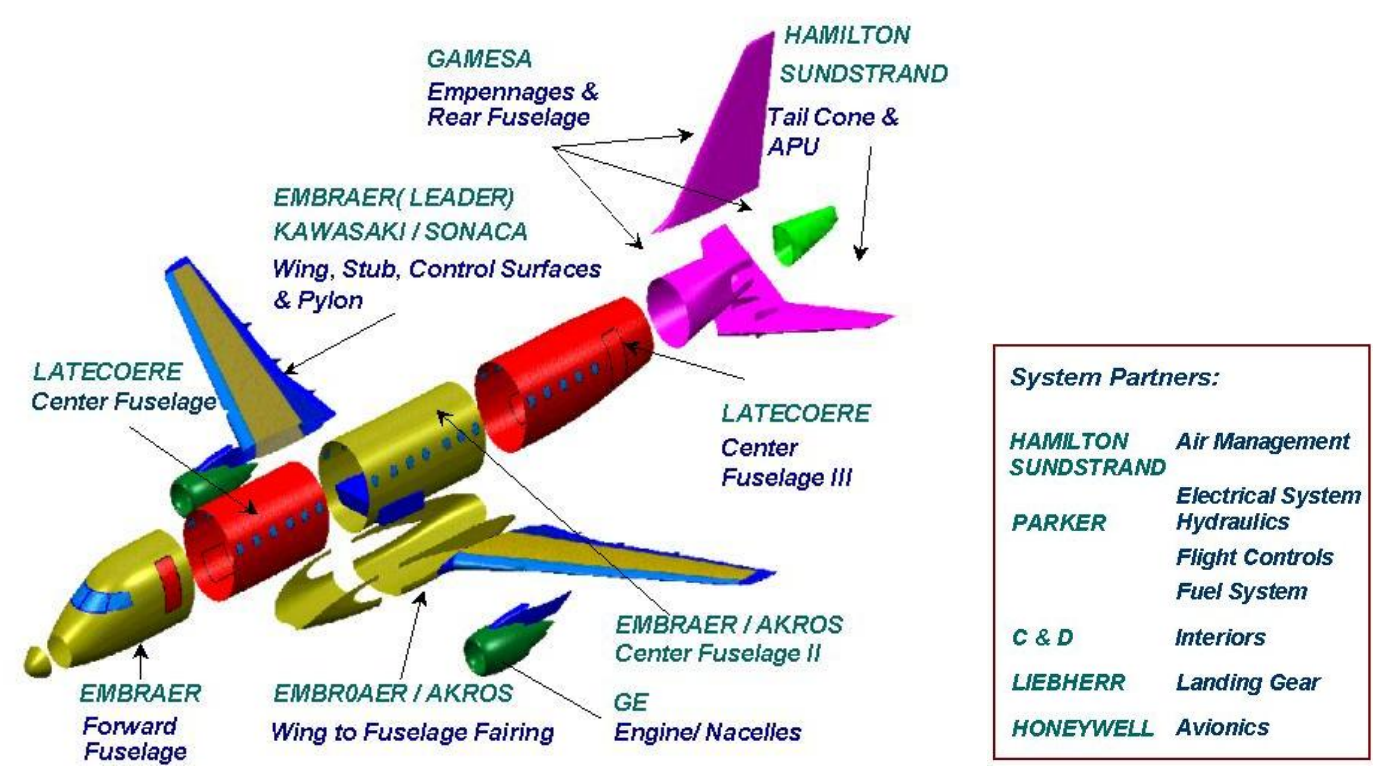

Figura 18 - Família E-Jets com 16 parceiros de risco e 22 fornecedores principais Fonte: Embraer (2008b). 
Nesse projeto, a empresa em estudo é também responsável pela concepção e pelo anteprojeto, pelo desenvolvimento e pela fabricação das fuselagens dianteira, central e carenagens de junção da asa/fuselagem, montagem da asa, além da integração e testes da aeronave. Uma particularidade desse programa é a comunicação totalmente eletrônica entre a empresa e seus parceiros, dispostos em quatro continentes. Para realizar essa comunicação foi criada a rede web 170 . Por meio dela, os participantes têm acesso à mesma base de dados, o que permite maior velocidade de troca de informações e menor possibilidade de erros de interpretação dos requisitos técnicos (PEREIRA, 2002). Com o objetivo apenas de ilustrar o posicionamento dos E-Jets nesse mercado, segue o Quadro 16, que traz os produtos da Embraer para aviação regional e seus principais concorrentes:

\begin{tabular}{|c|c|c|c|c|c|}
\hline \multicolumn{2}{|c|}{ 30-60 assentos } & \multicolumn{2}{|c|}{ Acima de 60 assentos } & \multicolumn{2}{|c|}{$30-60$ assentos } \\
\hline \multicolumn{2}{|c|}{ Turboélices } & \multicolumn{2}{|c|}{ Turboélices } & \multicolumn{2}{|c|}{ Jatos } \\
\hline Produto & Fabricantes & Produto & Fabricantes & Produto & Fabricantes \\
\hline ATR-42 & $\begin{array}{l}\text { Avions de Transport } \\
\text { Regional }\end{array}$ & ATR-72 & $\begin{array}{l}\text { Avions de Transport } \\
\text { Regional }\end{array}$ & ERJ 135,-140,-145 & Embraer \\
\hline Q300 & Bombardier & Q400 & Bombardier & CRI100,200,440 & Bombardier \\
\hline Antonov An-140 & Antonov ASTC & Ilyushin II-114 & Ilyshin & 328 Jet & Fairchild-Dornier \\
\hline MA60 & $\begin{array}{l}\text { Xi'an Aircraft Industrial } \\
\text { Corporation }\end{array}$ & BAE ATP & Bristish Aerospace & YAK-40 & Yakovlev \\
\hline EMB-120 & Embraer & & & & \\
\hline Dornier DO328 & Fairchild-Dornier & & & & \\
\hline Saab 340,2000 & Saab & & & & \\
\hline Fokker-50,F-27 & Fokker & & & & \\
\hline Jetstream41 & Bristish Aerospace & & & & \\
\hline \multicolumn{2}{|c|}{ 61-90 assentos } & \multicolumn{2}{|c|}{ 91-120 assentos } & \multicolumn{2}{|c|}{$121-210$ assentos } \\
\hline \multicolumn{2}{|c|}{ Jatos } & \multicolumn{2}{|c|}{ Jatos } & \multicolumn{2}{|c|}{ Jatos } \\
\hline Produto & Fabricantes & Produto & Fabricantes & Produto & Fabricantes \\
\hline EMBRAER 170,175 & Embraer & EMBRAER 190,195 & Embraer & EMBRAER 190,195 & Embraer \\
\hline CRJ701,705,900 & Bombardier & A318 & Airbus & A318 & Airbus \\
\hline $\mathrm{TU}-34$ & Tupolev & B737-600 & Boeing & B737-600 & Boeing \\
\hline BAE146-100,-200 & Bristish Aerospace & $\begin{array}{l}B 717,727-100,737- \\
100,-200,-500\end{array}$ & Boeing & $\begin{array}{l}B 717,727-100,737- \\
100,-200,-500\end{array}$ & Boeing \\
\hline AVRO-RJ70,-RJ85 & Bristish Aerospace & Fokker F100 & Fokker & Fokker F100 & Fokker \\
\hline Fokker F28,F70 & Fokker & $\begin{array}{l}\text { BAE146-300,AVRO- } \\
\text { R100 }\end{array}$ & Bristish Aerospace & $\begin{array}{l}\text { BAE146-300,AVRO- } \\
\text { R100 }\end{array}$ & Bristish Aerospace \\
\hline DC9-10,-20 & Douglas Aircraft & DC-9-30,-40,MD-87 & Douglas Aircraft & DC-9-30,-40,MD-87 & Douglas Aircraft \\
\hline ARJ-21 & $\mathrm{AMCl}$ & YAK-42, ВAC 111 & $\begin{array}{l}\text { Yakovlev, Bristihs } \\
\text { Aircraft Corporation }\end{array}$ & YAK-42, BAC 111 & $\begin{array}{l}\text { Yakovlev, Bristihs } \\
\text { Aircraft Corporation }\end{array}$ \\
\hline Antonov An-148 & Antonov ASTC & Superjet 100 & Sukhoi Corporation & Superjet 100 & Sukhoi Corporation \\
\hline Mitsubishi MR90 & Mitsubishi Regional Jet & CR1000,C110 & Bombardier & CR1000,C110 & Bombardier \\
\hline
\end{tabular}

Quadro 16 - Produtos da aviação comercial da Embraer e seus principais concorrentes

Fonte: Adaptado de Embraer, 2010d. 


\subsection{Jatos Executivos}

Nos anos 2000, a empresa se lança ao mercado de jatos executivos com a versão do Legacy 600 e do Legacy Shuttle, derivados da plataforma do ERJ 135. Ainda nessa década ela se arrisca no mercado dos Very Light Jets (VLJs), inicialmente ocupado pelas aeronaves Safire e Eclipse 500 de concorrentes diretos, conforme Mello (2005).

O lançamento do jato Legacy 600 marcou a entrada da empresa na aviação executiva, e tem sustentado bons resultados para a empresa. Os novos projetos dentro da linha executiva, como Phenom 100, Phenom 300, Lineage 1000 e o próprio Legacy 600 , estão no ranking dos melhores dentro de suas respectivas categorias, o que é justificado principalmente pelo bom desempenho e o baixo custo operacional, conforme Embraer, 2010b.

Em 2005 a empresa entregou 14 aviões executivos e em 2009 esse número aumentou para 115. Em 2008, a empresa lançou mais dois novos produtos, o Legacy 450 e 500, considerados na categoria de jatos médios, posicionados estrategicamente entre os Phenom300 e o Legacy 600 (BANDEIRANTE, 2008). A empresa estimou um valor de rendimento de 204 bilhões de dólares para os jatos executivos nos próximos dez anos, conforme Embraer (2008b).

A indústria aeronáutica tem nos fornecedores um importante elo de toda a cadeia. A mudança de seus parceiros para o Brasil aumenta o conteúdo nacional dos aviões da Embraer e reduz o volume de importação de peças. A norteamericana C\&D Aerospace, uma das principais fornecedoras da Embraer, iniciou em 2003 a operação da sua primeira fábrica na América do Sul, em Jacareí (SP), visando a atender a empresa. Outra fornecedora de peso, a Sobraer, instalada desde 2001 em São José dos Campos pela multinacional belga Socièté Nationale de Construction Aerospatiale (Sonaca), produz fuselagem de aviões e fornece suporte à produção da Embraer em todos os programas mantidos na América do Sul. A Parker Hannifin, fabricante de sistemas hidráulicos, comandos de voo e de combustível, instalou um centro de serviços em Jacareí para atender a companhia brasileira em 2003.

Outras empresas do grupo de fornecedores da Embraer, como a Pilkington 
Aerospace, escolheu São José dos Campos para fabricar as janelas da cabine de passageiros dos jatos ERJ-145 e Embraer 170, e a Goodyear reativou a linha de produção de pneus de avião na unidade industrial da empresa em São Paulo para atender a Embraer.

\subsection{Mercado de Defesa}

As aeronaves de defesa da Embraer apresentam tecnologia avançada. Os projetos começam com uma avaliação em profundidade da missão do cliente. Já foram atendidas cerca de 20 forças armadas do mundo inteiro para missões de vigilância, combate e treinamento. O segmento de defesa tem como maior cliente a Força Aérea Brasileira (FAB). O portfólio de produtos desse segmento contempla aeronaves para diferentes finalidades: inteligência, reconhecimento e vigilância (ISR), treinamento e combate, e transporte de autoridades civis e militares. Além disso, a Embraer presta serviço de suporte aos clientes de defesa, além de serviço de modernização das aeronaves da FAB.

Abaixo a descrição dos principais produtos fornecidos pela unidade de Defesa da Embraer.

\subsubsection{Aviões de Vigilância}

A família Embraer de aeronaves de inteligência, reconhecimento e vigilância (ISR) contempla os seguintes produtos: EMB 145 AEW\&C, EMB 145 Multi Intel e EMB 145 MP. Esses produtos são derivados da plataforma do jato regional ERJ145 com significativas mudanças na estrutura básica, equipada com sensores capazes de detectar e interpretar "alvos" (aviões, mísseis, barcos, veículos, instalações no solo e tipos de radiação eletromagnética e recursos naturais). As aeronaves de 
Inteligência, Reconhecimento e Vigilância são capazes de coletar e transmitir dados pelos sistemas de radar multimissão, incluindo comandos e controles a bordo. As imagens eletrônicas sobre objetivos em solo, ar ou mar são fornecidas em tempo real e recebidas por estações de comando e controles no solo ou em voo. A seguir um melhor detalhamento dessas aeronaves:

$\checkmark$ EMB 145 AEW\&C: é uma aeronave de alerta aéreo antecipado e controle, uma combinação da plataforma ERJ 145 com um sistema de radar multimissão desenvolvido pela Ericsson Microwave.

$\checkmark$ EMB 145 Multi Intel: Trata-se de uma aeronave de sensoriamento remoto e vigilância aérea do solo, capaz de fornecer imagens em tempo real. Ela possui sensores e radares que the permitem obter informações em pouco tempo.

$\checkmark$ EMB 145 MP: Aeronave destinada a missões de patrulhamento marítimo e missões antissubmarino. Projetada para ter sistemas de vigilância, ela contém as seguintes características: comunalidade com outras versões especiais, como EMB 145 AEW\&C e o EMB Multi Intel, comunalidade básica de plataforma com os 900 aviões de linha aérea regional em operação, e sistema de missão baseado em uma arquitetura aberta, permitindo que o EMB $145 \mathrm{MP}$ seja configurado de acordo com as necessidades de cada Força Aérea.

\subsubsection{Aviões de Combate e Treinamento}

Nessa categoria está o caça Super Tucano, um turboélice militar multifunção, monomotor. Essa aeronave possibilita treinamento e oferece soluções que contemplam desde o treinamento básico até o início do treinamento avançado e familiarização com armamento. 


\subsubsection{Aviões de Transporte}

As aeronaves militares de transporte fazem frente às necessidades de transporte de autoridades, de tropas/paraquedistas e às aplicações de carga e atendimento médico. Dentro dessa categoria está o Legacy 600TM, Legacy Shuttle, Família ERJ 145 e Família EMBRAER 170/190 de jatos para transporte de autoridades e demais aplicações. Originárias de plataformas comerciais, essas aeronaves combinam tecnologias de acordo com a necessidade do cliente. Encontra-se em desenvolvimento o mais novo programa da empresa, o programa da área de defesa KC-390, com entrada prevista para 2015. A FAB estabeleceu os requisitos para essa aeronave assim como o fez para o desenvolvimento do Bandeirante, do Tucano, do Super Tucano e das versões de vigilância área e de sensoriamento remoto do ERJ 145 utilizadas no Sistema de Vigilância da Amazônia (SIVAM). O KC-390 poderá ser reabastecido em voo e também utilizado para reabastecimento de outras aeronaves, em voo e em solo. A cabine de carga permitirá configuração para missões de evacuação médica (Medical Evacuation MEDEVAC). Os avanços técnicos do KC-390 incluem a tecnologia fly-by-wire, que diminui a carga de trabalho dos pilotos, otimizando o cumprimento da missão e aumentando a segurança e capacidade de operar em pistas curtas semipreparadas.

\begin{tabular}{|l|l|}
\hline \multicolumn{1}{|c|}{ Aeronave } & \multicolumn{1}{c|}{ Descrição } \\
\hline EMB 312 “Tucano" & $\begin{array}{l}\text { Aeronave turboélice de treinamento militar e líder mundial no seu } \\
\text { segmento de mercado }\end{array}$ \\
\hline Super Tucano "ALX" & $\begin{array}{l}\text { Aeronave militar de treinamento e aplicações operacionais de vigilância de } \\
\text { fronteiras e espaço aéreo, derivado do EMB 312. }\end{array}$ \\
\hline AMX-T & $\begin{array}{l}\text { Jato de ataque subsônico militar, para missões táticas, desenvolvido em } \\
\text { consórcio com a Aeritalia. }\end{array}$ \\
\hline
\end{tabular}

Quadro 17 - Primeiras aeronaves da área de defesa.

Fonte: Adaptado de Bastos (2006).

O próximo capítulo abordará os resultados da pesquisa. É importante frisar que a maior parte dos resultados aqui apresentados foram decorrentes das entrevistas e checados com diversas áreas. 


\section{RESULTADOS}

\subsection{Identificação das Práticas de Desenvolvimento de Produto: Decisões de Make or Buy e Definição de Parceiros e Fornecedores.}

Nesta primeira parte dos resultados procurou-se, através das questões sobre o processo de decisão de make or buy e de desenvolvimento de produto, entender como surge um novo projeto e como se dá o escopo de parceria na empresa em estudo, além da documentação pesquisada para suportar a pesquisa.

Segundo as entrevistas, um novo projeto começa dentro da Diretoria de Anteprojeto da empresa com as suas equipes de Estudos Conceituais (desenvolvendo o conceito do produto) e de Estudos Preliminares (detalhando e testando a viabilidade tecnológica e econômico-financeira). Se os estudos mostram a viabilidade, ou seja, se há grandes chances de o mercado pagar o preço inicialmente estipulado, começa o trabalho com a equipe de nucleação entrando na Initial Definition Phase (IDP), fase que será detalhada na próxima subseção. Essa equipe elabora o Business Plan (BP), que contém as principais definições sobre o local de fabricação, orçamento, decisão de fabricar ou terceirizar e escolha dos principais fornecedores, dentre eles fornecedores de motor, aviônica, trem de pouso etc. Para essas decisões de fabricação interna ou não, também são envolvidos 0 Planejamento Estratégico e o Financeiro. A partir daí surgem as definições sobre a arquitetura do produto integral ou modular e, consequentemente, o impacto na cadeia.

A análise financeira para tomada de decisão make or buy considera os custos de fabricação interna versus o custo da terceirização, assim como a capacidade produtiva da empresa e de suas filiais, como Gavião Peixoto e Botucatu, por exemplo. Também é considerado o volume de produção no longo prazo. Por exemplo, o programa Phenom teve a decisão de produção da fuselagem interna, mas com o aumento da produção tal decisão está sendo revista, pois a empresa já não está suportando a demanda. Além disso, são considerados outros aspectos estratégicos. Por exemplo, o estabelecimento da fábrica em Portugal (em Évora) 
para o desenvolvimento de material composto e fabricação da asa do Legacy 450/500 envolveu subsídios, incentivos dos países europeus e equilíbrio da balança comercial dos países envolvidos nesse projeto. Em linhas gerais, a decisão é baseada em alguns drivers como:

- time to market;

- análise financeira;

- situação da economia;

- particularidades do programa; e

- capacidade produtiva.

Após essas primeiras análises o BP é finalizado, apresentado e, se aprovado pela Diretoria, monta-se o Core Team, equipe composta por diversos profissionais de diversas áreas da empresa como: suporte ao cliente, produção, área de gestão de programa, gestão dos fornecedores, qualidade e comercial. Essa equipe integrará, de forma multifuncional, o conhecimento de suas áreas para o desenvolvimento do produto (Figura 19). Inicia-se a fase de definição conjunta, chamada Joint Definition Phase (JDP), em que os maiores fornecedores (10 maiores) têm que ser definidos até meados dessa fase. Essa metodologia de desenvolvimento integrado do produto foi iniciada no programa 170 e é aplicada até hoje aos novos programas. 


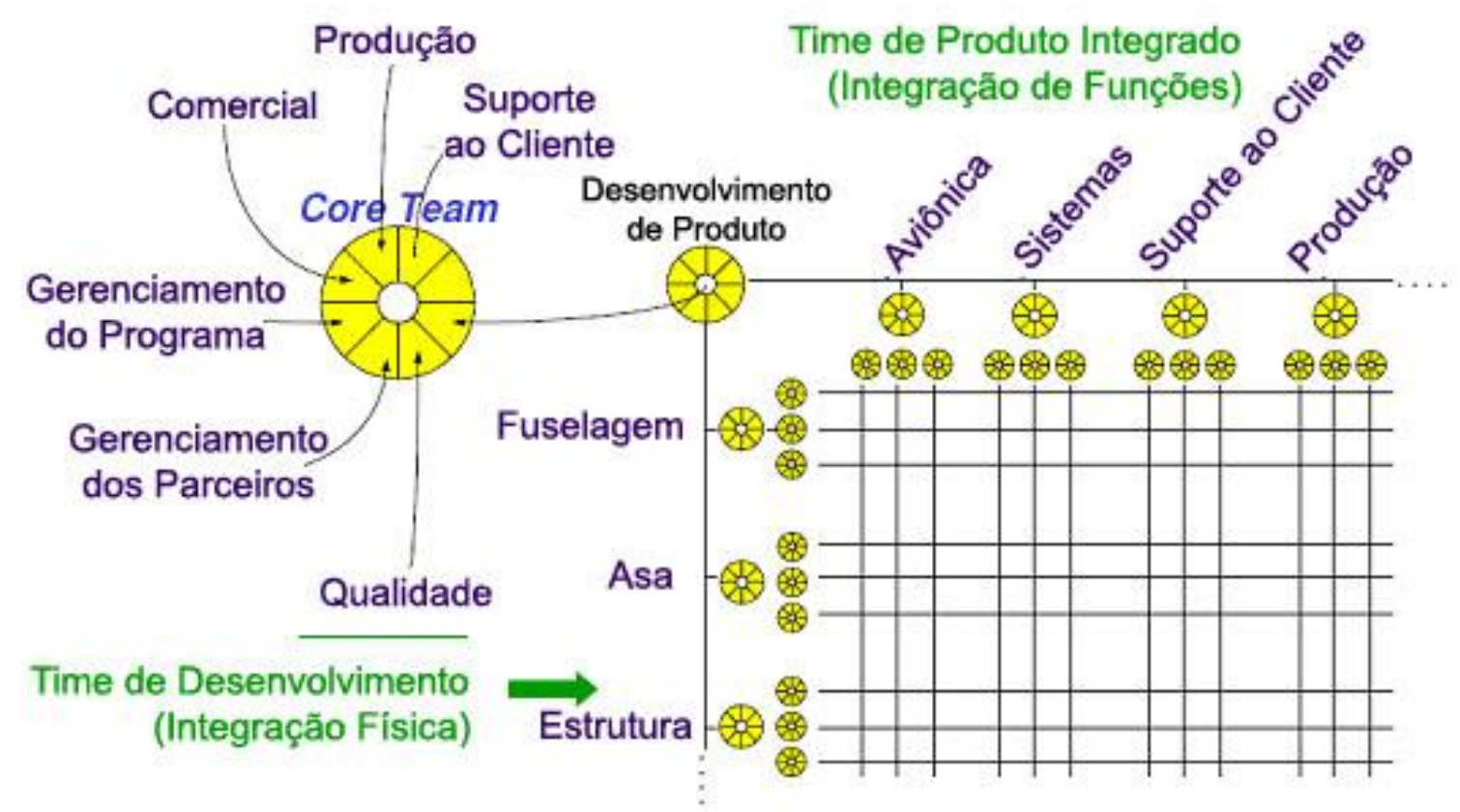

Figura 19 - Core Team

Fonte: Embraer (2009a).

Para Machado (2005), o que destaca a Embraer é o fato de ter processo mais horizontal de Pesquisa e Desenvolvimento (P\&D) do que os concorrentes. Sendo a empresa orientada pela engenharia e pelo mercado, ela apresenta uma série de características em relação ao processo de concepção e desenvolvimento de produto, segundo Machado (2005):

a) Investe em capital intelectual;

b) Apresenta capacidade de integração;

c) Trabalha com o conhecimento colaborativo: os produtos da Embraer são desenvolvidos através da concepção de desenvolvimento integrado e, por fim;

d) Apresenta uma cultura que combina tecnologia e aspectos mercadológicos do negócio.

O aprendizado com O ERJ 145 foi a base para o aprofundamento da organização do primeiro nível da cadeia de suprimentos por meio de contratos de risco. No programa 170/190 houve considerável diversificação e extensão da estratégia, com o desenvolvimento da maior parte dos sistemas importantes do projeto da aeronave em conjunto com os parceiros, comentam Montoro e Migon (2009). O programa 170 representou uma grande evolução para a empresa no que se refere ao desenvolvimento do produto e gestão de negócio: 
Essa estratégia de co-design permitiu à Embraer reduzir em $30 \%$ o tempo necessário para o desenvolvimento do produto, na prática, o equivalente a quase um ano e meio (o processo que era realizado em 54 meses foi completado em 38 meses). As vantagens em termos da economia de investimento dessa nova família, orçada em US $\$ 1$ bilhão, pelo menos um terço foi de responsabilidade dos parceiros (MIRANDA, 2007, p. 107).

\subsubsection{Da Elaboração do Projeto à Fabricação da Aeronave}

No programa 170 foi aplicado um conceito de gestão que a empresa denominou como Desenvolvimento Integrado de Produto (DIP), o qual foi organizado em três fases, conforme explica Oliveira (2005) e pode ser visualizado na Figura 20.

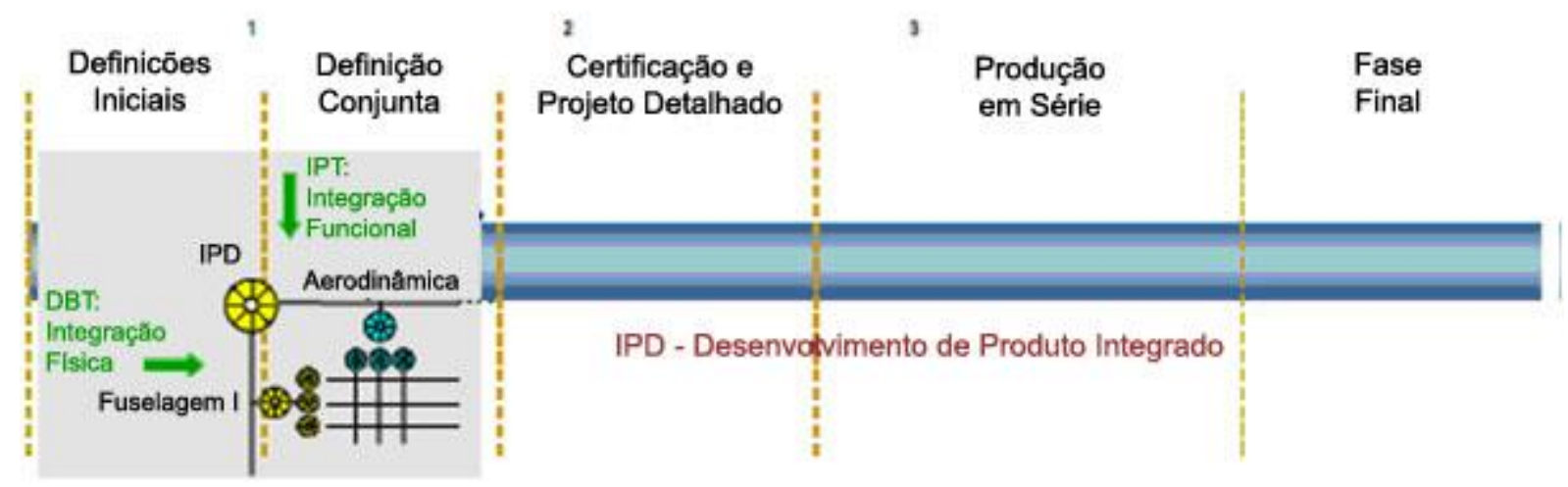

Figura 20 - Desenvolvimento Integrado do Produto

Fonte: Embraer (2009a).

\section{a) Fase 1 - Definições Iniciais}

Nesta fase é desenvolvida a concepção, o projeto preliminar. O resultado é um plano de negócio que aborda: requisitos de mercado e uma concepção inicial do produto, o planejamento de custos, a análise do ciclo de vida, a análise de risco e retorno do investimento, e o estudo específico de identificação do mercado.

\section{b) Fase 2 - Definição Conjunta}

Nessa fase o avião é repartido em vários segmentos, ocorre a divisão do trabalho pelas empresas participantes do projeto e a definição conjunta dos parâmetros da aeronave entre os parceiros e a Embraer. A inovação se deu principalmente pela internacionalização das rotinas de $P \& D$, ou seja, a fase do 
desenvolvimento do produto contou com a participação dos parceiros internacionais. Em outras palavras, aplicou-se uma filosofia que a empresa denominou como engenharia colaborativa, conectada a sites globais, isto é, uma rede de P\&D entre plantas e laboratórios dos diversos parceiros internacionais, centralizada e coordenada pela Embraer. Essa estratégia foi possível também pela criação de equipes multidisciplinares descentralizadas, cujo modelo impactou toda a empresa e foi suportado por ferramentas para desenvolvimento em conjunto de partes do avião com o parceiro. Tal procedimento permitiu o desenvolvimento integrado do produto, uma vez que as tomadas de decisões sobre os aspectos técnicos das partes do avião em desenvolvimento eram feitas por especialistas que representavam a empresa parceira e que detinham autoridade para decidir. Tais especialistas ficavam na Embraer e faziam parte das equipes multidisciplinares.

A Embraer conduziu o trabalho de engenharia pelo centro de computação avançado, propiciando um ambiente de projeto integrado. Ela contou com a implantação de sistemas web e Electronic Data Interchange (EDI), conectados ao canal de satélite, permitindo ligar on-line a rede de empresas parceiras ao mock-up e ao banco de dados do programa.

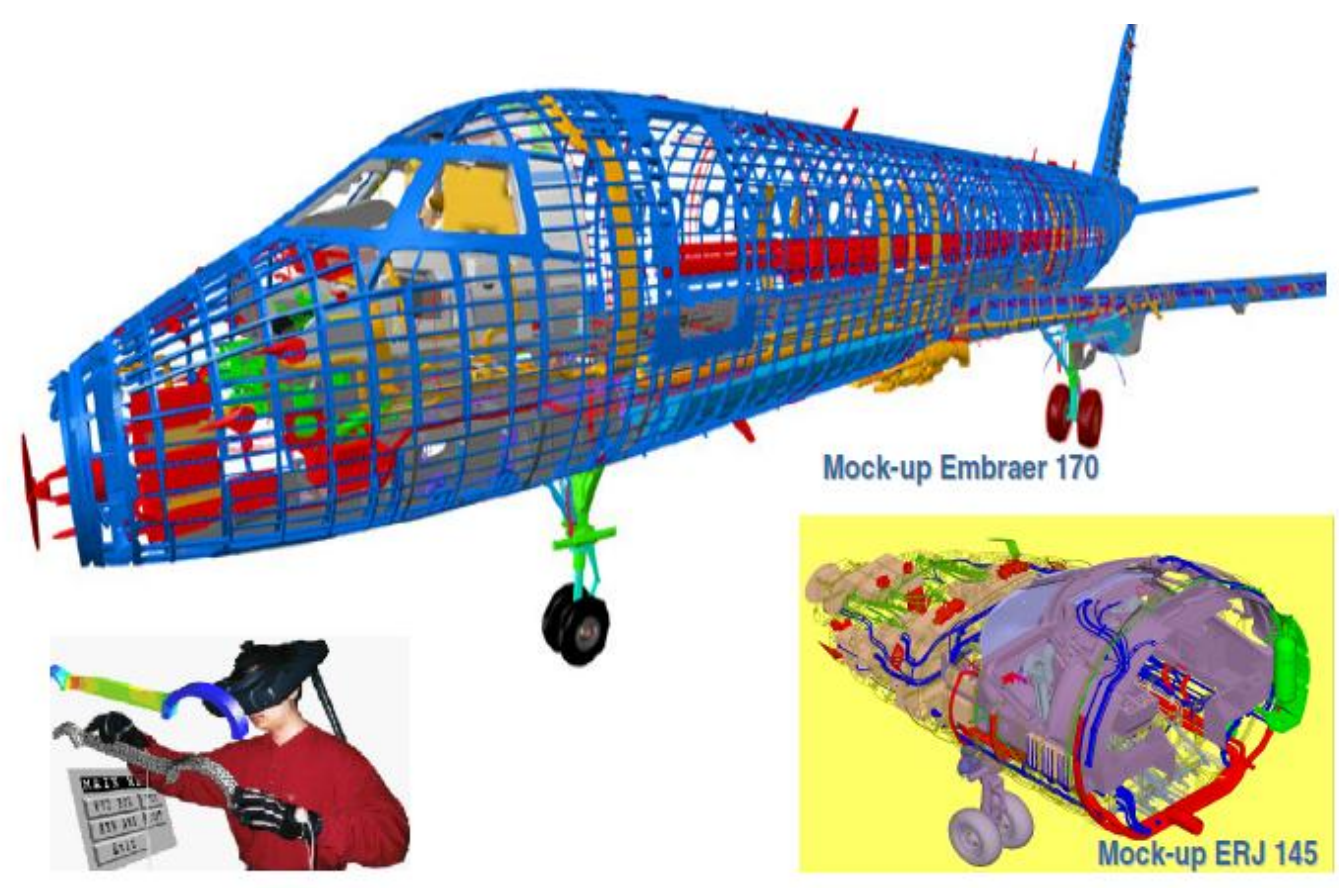

Figura 21 - Mock-up Digital Fonte: Embraer (2009a).

As modificações no design do projeto efetuadas pelos parceiros e 
fornecedores eram enviadas eletronicamente para a Embraer, onde eram checadas e validadas para depois serem atualizadas no mock-up e no banco de dados do programa. Esse novo sistema de transmissão de informações permitiu a configuração de uma arquitetura empresarial em rede, com redução de custos transacionais, possibilitando um processo de trabalho em rede.

Preocupada com as interfaces e padronizações, a empresa estipulou um padrão organizacional em termos de software, permitindo que o conhecimento fosse codificado, de forma a aumentar a velocidade e precisão do trabalho.

\section{c) Fase 3 - Certificação e Projeto Detalhado}

Nesta fase estão os trabalhos de finalização e definição final da configuração da aeronave para a certificação nos órgãos homologadores. Os especialistas, que trabalharam nas equipes multidisciplinares da fase de definição conjunta (engenheiros e técnicos dos parceiros e fornecedores), retornaram aos seus países para terminar as fases de detalhamento, e continuam enviando as informações via EDI.

\subsubsection{Fase de Produção}

A seguir descrevemos de maneira sucinta o processo de produção da aeronave no sentido de completar o processo desde o desenvolvimento do produto até sua fabricação e entrega ao cliente. O processo de produção é divido em cinco grandes fases:

\section{A) Partes do fornecedor (matéria-prima)}

A Embraer compra principalmente matéria-prima de baixo peso e de alta resistência, como ligas de alumínio, titânio, aço inoxidável e material composto.

\section{B) Fabricação das peças}

A chapa de alumínio é conformada de acordo com a curvatura da aeronave. Os painéis de revestimento (skin) da fuselagem são afixados em componentes estruturais primários, como as cavernas (frames) e reforçadores (stringers). Os painéis são ajustados às suas dimensões e formas finais por uma máquina 
computadorizada de controle numérico $(\mathrm{CNC})$ de cinco eixos. Depois da fabricação dos painéis e revestimento da fuselagem é realizado um tratamento superficial anticorrosão.

\section{C) Montagem da Fuselagem}

Os painéis são unidos às cavernas e aos reforçadores por meio de rebitagem, dando origem ao segmento de fuselagem. Um selante é então aplicado de modo a garantir a pressurização da cabine e evitar vazamentos (Figura 22).

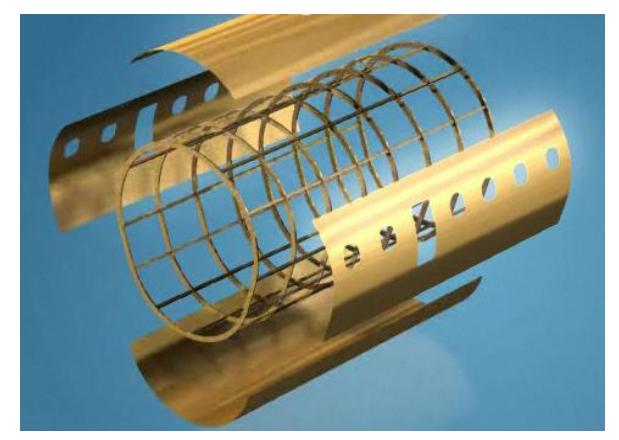

Figura 22 - Montagem da Fuselagem Fonte: Embraer (2009b).

Após a fabricação dos principais segmentos da fuselagem, estes são unidos por rebites e cintas completando a fuselagem, também conhecida como "charuto", conforme mostra a Figura 23.

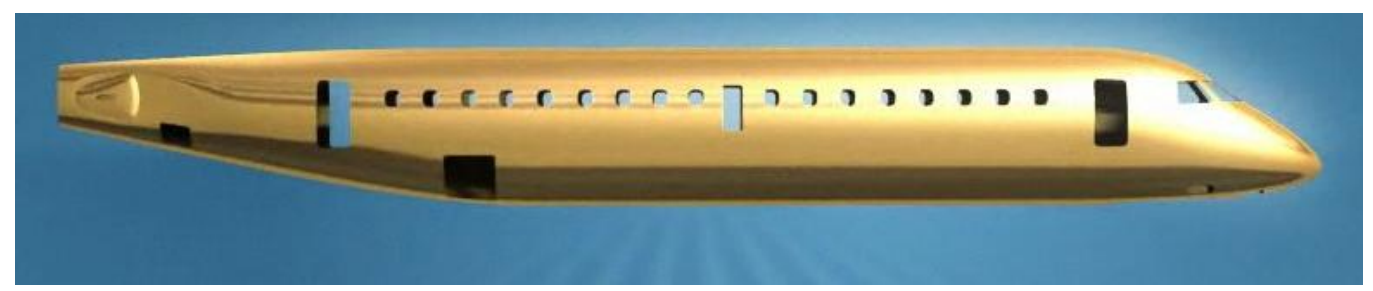

Figura 23 - Junção da fuselagem Fonte: Embraer (2009b).

Dutos, fios, cabos, sistemas hidráulicos, válvulas e outros equipamentos são instalados. A fuselagem é então pintada de acordo com as cores do cliente em uma cabine de pintura fechada com temperatura e pressão controladas. 


\section{D) Montagem Final}

Os principais componentes, a maior parte proveniente dos principais fornecedores, como asas, motores, estabilizadores e trens de pouso, são integrados à fuselagem. Os sistemas aviônicos, hidráulicos, de combustível e de comando de voo, bem como assentos, copa (galley) e toalete, entre outros componentes, são instalados (Figura 24).

Todos os controles e sistemas são inspecionados e testados por meio de bancada integrada de testes. Os voos de produção são realizados para cumprir todos os requisitos dos projetos e de fabricação, bem como atender aos padrões de autoridade de certificação para a emissão do certificado de aeronavegabilidade.

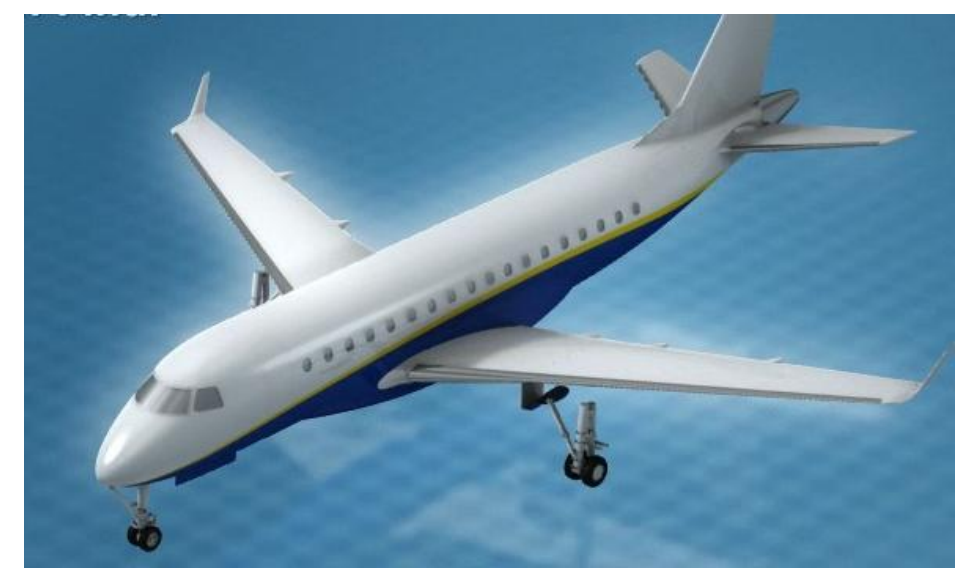

Figura 24 - Montagem dos componentes

Fonte: Embraer (2009b).

\section{E) Entrega da aeronave}

Após a conclusão dos ensaios em solo, dos voos de produção e da respectiva documentação, a aeronave está pronta para ser entregue ao cliente. Inicia-se então o processo de entrega com a inspeção em solo e em voo pelo cliente, seguida da aceitação técnica e troca de documentação com transferência da propriedade. 


\subsection{Identificação de Práticas de Alianças Estratégicas: Definições de Parcerias e Impactos Financeiros}

$\mathrm{Na}$ pesquisa de campo, procurou-se, através das questões sobre parceria, entender as diferenças das relações entre parceiros e fornecedores e o impacto financeiro atrelado ao projeto que essas alianças trazem. As práticas de alianças, como o estabelecimento de joint-ventures, também foram identificadas por análise de documentos.

A relação entre alianças, parcerias e inovação foi constatada na Embraer através das relações com os fornecedores e a interação entre o fluxo de ideias provenientes da cooperação, que trouxeram inovações técnicas e comerciais para os vários níveis da empresa, principalmente nos projetos 145 e 170, explica Junior (2006). A Embraer desempenha o papel de integrar os sistemas, sendo a principal aglutinadora da cadeia produtiva. A rede na qual está inserida também compreende outros agentes, como centros de pesquisa e universidades, com o objetivo de estabelecer alianças estratégicas para se obter inovação.

A empresa estabeleceu algumas joint-ventures ao longo de sua história. Em 1999 estabeleceu joint-venture com a empresa europeia Liebherr Aerospace SAS, de onde surgiu a Embraer Liebherr Equipamentos do Brasil (ELEB) para fornecimento de trem de pouso; em 2008, a própria Embraer adquiriu a totalidade das ações da ELEB. Outra joint-venture estabelecida foi na China, com a Harbin Aircraft Industry Group Co. Ltd e a Hafei Aviation Industry Co. Ltd, controladas pela AVIC II, de onde surgiu a empresa Harbin Embraer Aircraft Industry Company Ltd, com o objetivo de melhor atender o mercado chinês de aviação comercial. A Embraer também estabeleceu joint-venture com a European Aeronautic Defense and Space Company (EADS), de onde surgiu a Airholding SGPS S/A, com 99\% de participação acionária da Embraer para a compra de 65\% do capital da OGMA, situada em Portugal, com o objetivo de manutenção e reparo de aeronaves da Embraer na Europa.

Para Junior (2006), o desafio de inovar e criar valor simultaneamente, identificando e desenvolvendo o mercado com o qual a Embraer se deparou, apenas foi possível com a utilização de alianças e parcerias estratégicas. 
A gestão colaborativa no desenvolvido do produto utilizada pela Embraer com seus parceiros e fornecedores foi algo inovador, segundo Miranda (2007):

Concomitantemente, foi incorporado pela empresa o trabalho em parceria. A instituição desse processo de gestão de desenvolvimento de produtos ocorreu no começo de 1990 e foi denominada "sistemas de parceria de custos e riscos". Foi uma verdadeira inovação no conceito de gestão produtiva na empresa (MIRANDA, 2007, p. 105).

O programa ERJ 145 desenvolvido no início da década de 1990 teve como princípio norteador a economia de custos, uma vez que a empresa passava por grandes dificuldades. A empresa tentou aproveitar ao máximo o conhecimento interno para desenvolver a nova aeronave, segundo entrevistas. Foi com a privatização, em 1994, que grandes mudanças na forma de gestão interferiram no projeto ERJ 145, mas devido às grandes dificuldades financeiras para tirá-lo do papel e alcançar escala industrial, a Embraer se associou a fornecedores estrangeiros, surgindo as parcerias de risco. Conforme citado em Montoro e Migon (2009), os parceiros de risco financiaram mais de US $\$ 100$ milhões dos US $\$ 300$ milhões necessários para o desenvolvimento do projeto. Ainda segundo os autores Montoro e Migon (2009), no programa 170 os parceiros entraram com mais de US $\$ 300$ milhões do custo total do projeto, estimado em US $\$ 950$ milhões.

Conforme entrevistas, o parceiro de risco, para entrar no programa, ajuda no financiamento e na criação do projeto; em troca pode receber, por exemplo, exclusividade de fornecimento, ou seja, ele será o fornecedor exclusivo de determinado equipamento até o fim do programa e dará suporte aos clientes por toda a frota. A Embraer se compromete a não trocar de fornecedor e ele passa a ser o único certificado pela empresa para o fornecimento. Já é de praxe ter como parceiro os fornecedores de componentes de demanda grande e/ou de alto valor agregado como motor, aviônica, estrutura etc. Os parceiros assumem o risco do desenvolvimento e os gastos para o desenvolvimento do componente, divididos em custos recorrentes (custos repetitivos) e não recorrentes (vinculados diretamente com o desenvolvimento do produto).

O retorno desse investimento se dá através das compras dos conjuntos fornecidos para a Embraer (shipsets). Os primeiros shipsets são mais caros, com o intuito de pagar o custo de desenvolvimento acarretado pelo fornecedor. Segundo levantamento feito nas entrevistas, o valor da parcela acrescida nos shipsets, assim como a quantidade de shipsets afetados são negociados caso a caso, e para tal 
cálculo também se considera a quantidade de aviões previstos no BP. $\mathrm{O}$ valor retornável via pagamento do shipsets é ajustado anualmente, conforme a fórmula de reajuste (escalation) definida em cada contrato, geralmente regida pelos índices americanos de inflação. Portanto, a definição de parceria de risco está fortemente atrelada ao investimento que o fornecedor faz no projeto.

O escopo de parceria também pode ser entendido não só sob o ponto de vista de investimento, mas também de tecnologia e desenvolvimento do produto, como foi abordado nas entrevistas. No programa 145, a Embraer tinha a concepção do produto, tinha domínio tecnológico sobre o desenvolvimento, e o parceiro entrava no projeto e na fabricação. No programa 170, a Embraer teve menos domínio sobre o desenvolvimento (nesse sentido ela é mais dependente do fornecedor). O parceiro participa da concepção do produto, do projeto e da fabricação. Por exemplo, a tecnologia fly by wire foi uma tecnologia que a Embraer e a Honeywell se capacitaram juntas para desenvolver. No entanto, somente a Honeywell possuía conhecimento para mexer na aviônica. Para os programas novos, Phenom e Legacy 450/500, a Embraer se capacitou tecnologicamente para não depender do fornecedor e, nesse sentido, se assemelha ao programa 145, em que o fornecedor participa mais apenas na fabricação. Já para o KC-390 suas estratégias são mais parecidas com a do programa 170. Existe uma dependência maior dos fornecedores e clientes para o desenvolvimento.

Com relação ao questionamento feito sobre a relação de parceiros e fornecedores ao longo do programa, foi constatado que a Embraer deixou de ter uma dependência financeira como teve, por exemplo, no programa 145 e se capacitou mais tecnologicamente. Com isso diminui sua dependência ao longo dos programas. No programa 145 havia uma necessidade de ter o processo de parceria de risco, pois a Embraer precisava de investimento e do compartilhamento de risco. As especificações técnicas contidas no documento RFP (Request for Proposal), utilizadas no processo de seleção, eram, no entanto, mais rigorosas, tanto para o parceiro quanto para o fornecedor.

Já no programa 170 os critérios técnicos contidos na RFP eram menos detalhados. A não exigência de especificações técnicas, como feita pela maioria dos fabricantes na época, foi proposital. A Embraer criou no processo de seleção os High Level Requirements, que traziam requisitos gerais sem grandes especificações. Isso foi uma forma de a empresa forçar a integração entre os próprios fornecedores 
e a Embraer nas fases de definição conjunta do desenvolvimento do produto, conforme entrevistas.

O programa KC-390 está no mesmo contexto que estava o programa 145 no seu lançamento, ou seja: há a necessidade de investimento e falta de capacidade produtiva (local de fabricação), conforme entrevistas. No entanto, a estratégia de parceria é com o próprio cliente, nesse caso a Força Área Brasileira (FAB), que assume o desenvolvimento e os ativos do processo (local e ferramental). A Embraer participa com mão-de-obra e tecnologia.

Nesse sentido o que se percebe é que a capacitação da Embraer se deu ao longo dos programas. A estratégia adotada com os High Level Requirements forçou a integração e o compartilhamento do conhecimento, o que repercutiu em capacitação não só para Embraer, que hoje é capaz de utilizar tais conhecimentos em seus novos programas, como o KC-390, como também para os fornecedores, que passaram a dominar a integração do componente fornecido, o que os elevou à categoria de integradores.

Com relação ao questionamento feito sobre os critérios e fatores atribuídos no processo de seleção de fornecedores, verificou-se que no mercado aeronáutico não há uma grande quantidade de fornecedores de um mesmo item e é muito comum empresas concorrentes terem o mesmo fornecedor, como ocorre entre Boeing, Airbus, Embraer e Bombardier. O processo inicia-se com o envio da RFP, que contém requisitos técnicos e comerciais exigidos para os vários fornecedores potenciais. A continuidade do processo se dá através da análise das respostas desses documentos, pelos testes dos produtos e pelas negociações subsequentes. Diversas áreas da empresa participam do processo, como: qualidade, compras, engenharia, comercial, programas, pós-venda e marketing. Foi mencionado durante as entrevistas que a empresa utiliza como ferramenta de suporte para a pontuação dos critérios a tabela Kepner-Tregoe (KT - veja exemplo no Quadro 18). Através dela são atribuídos pesos e notas para os requisitos. 


\begin{tabular}{|c|c|c|c|c|c|c|c|}
\hline \multirow[b]{2}{*}{ Requisitos } & \multirow[b]{2}{*}{$\begin{array}{l}\text { Peso } \\
\text { (p) }\end{array}$} & \multicolumn{2}{|c|}{ Empresa A } & \multicolumn{2}{|c|}{ Empresa B } & \multicolumn{2}{|c|}{ Empresa C } \\
\hline & & $\begin{array}{l}\text { Nota } \\
(\mathrm{N})\end{array}$ & $(\mathrm{P}) \times(\mathrm{N})$ & $\begin{array}{l}\text { Nota } \\
(\mathrm{N})\end{array}$ & $(\mathrm{P}) \times(\mathrm{N})$ & $\begin{array}{l}\text { Nota } \\
(\mathrm{N})\end{array}$ & $(\mathrm{P}) \times(\mathrm{N})$ \\
\hline 1. Suporte de Campo & 8 & 3,0 & 24,7 & 2,8 & 23,0 & 2,8 & 23,0 \\
\hline 2. Suporte Técnico & 6 & 2,5 & 15,3 & 2,8 & 17,2 & 2,5 & 15,3 \\
\hline 3. Programa de Manutenção & 6 & 3,0 & 18,4 & 3,0 & 18,4 & 2,0 & 12,3 \\
\hline $\begin{array}{l}\text { 4. Garantia de Custo de } \\
\text { Manutenção }\end{array}$ & 21 & 3,0 & 62,3 & 4,0 & 83,1 & 2,0 & 41,6 \\
\hline 5. Confiabilidade da Frota & 37 & 2,5 & 93,7 & 3,0 & 112,5 & 2,0 & 75,0 \\
\hline 6. Manutenabilidade & 4 & 3,0 & 10,8 & 3,0 & 10,8 & 3,0 & 10,8 \\
\hline 7. Boletim de Serviço & 17 & 3,0 & 51,6 & 3,0 & 51,6 & 3,0 & 51,6 \\
\hline 8. Publicações Técnicas & 17 & 3,0 & 51,6 & 3,5 & 60,2 & 4,0 & 68,8 \\
\hline 9. Treinamento & 12 & 3,0 & 37,3 & 3,0 & 37,3 & 3,0 & 37,3 \\
\hline 10. Suporte de Material & 37 & 3,0 & 112,5 & 1,5 & 56,2 & 1,5 & 56,2 \\
\hline 11. Estações de Reparo & 17 & 2,5 & 43,0 & 2,0 & 34,4 & 2,0 & 34,4 \\
\hline
\end{tabular}

Quadro 18 - Método KT de seleção

Fonte: Vieira (2004).

Os entrevistados mencionaram os principais critérios que nortearam as decisões nos programas investigados. Em linhas gerais, os critérios dependerão dos requisitos de mercado. É importante informar que tanto os critérios como as estratégias se originaram no grupo de Estudos Preliminares, podendo haver requisitos de custos baixos, necessidade de fabricação fora do país etc.

Para a família 145 os critérios se deram com foco no investimento. A Embraer precisava captar recursos financeiros: a escolha foi baseada nos fornecedores que estavam dispostos a investir. Além disso, houve contribuição de recursos das duas partes. A Gamesa, por exemplo, foi desenvolvida com a ajuda da Embraer, já que tinha dinheiro pra investir mas não dominava muito a tecnologia a ser fornecida.

Para a família E-Jets o cenário era outro: a empresa estava em uma situação financeira melhor e a capacitação tecnológica foi um dos principais critérios que nortearam o programa. A quantidade de parceiros foi maior, mas o principal requisito era ter fornecedores que dominassem a tecnologia fornecida e fossem integradores do sistema. Daí ter que dominar os "pacotes" de fornecimento, como o sistema de ar condicionado (AMS - Air Management System) fornecido pela Hamilton e o trem de pouso fornecido pela Liebherr em parceria com a EDE, que antes (no programa 145) envolvia mais de 30 fornecedores, por exemplo.

Para o Phenom o custo era o diferencial do projeto. Portanto, baixo custo foi 
um critério forte na escolha dos fornecedores. Era preciso selecionar fornecedores de qualidade, mas com preço baixo nos produtos fornecidos. $O$ avião, para ser competitivo no mercado, tinha que ser mais barato se comparado com seus concorrentes diretos. A capacidade tecnológica também foi um critério perseguido e, acima de tudo, o time to market: a empresa não podia esperar o desenvolvimento $\mathrm{e}$ capacitação de alguns fornecedores, que poderiam levar anos. Por isso, muitas vezes, acabou sendo escolhido o fornecedor que já tinha o produto pronto e cujo desenvolvimento ou melhoria não consumiriam muito tempo, ainda que não fosse a escolha ideal. Outra consequência disso foi a decisão da própria Embraer de fornecer algumas partes da estrutura desse avião: era mais rápido e mais barato do que terceirizar. Outro exemplo: para facilitar as vendas do Phenom nos Estados Unidos, foi preciso estabelecer uma fábrica na cidade de Melbourne (EUA) e garantir a facilidade de suporte ao cliente.

Já para os Jatos Médios (Legacy 450/500) os critérios foram mais ponderados, isto é, utilizaram-se os critérios do E-Jets e do Phenom. Foram considerados os recursos financeiros captados pelos fornecedores e sua capacitação tecnológica, e deu-se preferência a fornecedores capazes de fazer integração. Além disso, houve uma grande procura por parte dos fornecedores para entrar no projeto, o que ajudou a estabelecer critérios mais seletivos nas negociações.

Por fim, o programa KC-390 é considerado um caso atípico, programa militar, regido por fases. Traz um risco menor, pois à medida que a fase avança, o cliente libera o pagamento. A escolha do fornecedor é tomada em conjunto pela Embraer e pelo cliente. O caso do KC-390 (contratos de off-set) envolve a necessidade de parceria com o país de aquisição.

Existem os requisitos básicos presentes em todos os programas durante 0 processo de seleção, como a saúde financeira da empresa, os incentivos fiscais, benefícios e critérios políticos. 


\subsection{Identificação das Competências Modulares}

A empresa em estudo apresenta competências modulares na arquitetura de seu produto e, consequentemente, na sua forma de organização em redes. $\mathrm{O}$ avião depende do fornecimento de módulos de seus fornecedores. Por exemplo, o radar, considerado um módulo fornecido pela Ericsson para o projeto EMB 145 AEW\&C, entre outros componentes provenientes de outros fornecedores, como o sistema de propulsão, sistema aviônico, sistema de ar condicionado, sistemas hidráulicos e pneumáticos, estrutura, sistema de trem de pouso e interiores. No entanto, essa característica de modularidade não se pode comparar, por exemplo, com o consórcio modular de empresas automobilísticas como a Volkswagen, apresentado nos estudos de Salerno (2001) e Marx et al. (1997).

Foram constatadas na empresa as características de padronização de interfaces e comunalidade típicos de produtos modulares, conforme Sturgeon (2002) e Langlois (2001). Durante a fase de desenvolvimento do produto (Joint Definition Phase - JDP), a Embraer exige a presença física em sua fábrica dos representantes técnicos de seus principais fornecedores para a padronização dos módulos, de forma a coordenar e permitir a integração entre eles. Os principais fornecedores de grandes sistemas, dentre eles os parceiros de risco, são responsáveis pelos subsistemas e estabelecem interações predominantemente modulares com seus fornecedores de componentes. A empresa em estudo tem grande preocupação em buscar a comunalidade entre os itens das diversas plataformas; por exemplo, 0 ERJ145 tem 30\% de comunalidade em partes e componentes com o Brasília, segundo Montoro e Migon (2009). A família E-Jets foi desenvolvida pensando na comunalidade entre os produtos da família (170 e 190). Para o Legacy 450/500 a tendência é o fornecimento de partes mais completas, ou seja, os sistemas têm que estar preparados para a Embraer apenas montar (estratégia plug and play), conforme entrevista com a área de Engenharia. Com a estratégia plug and play, tendência para os novos projetos, a Embraer não precisa gastar tempo com sua mão-de-obra instalando cabos dentro das estruturas fornecidas. Outra estratégia são os pacotes de configuração oferecidos aos clientes da aviação executiva, que escolhem a disposição física dos itens internos como assentos, armários, divãs, 
entre outros, assim como o detalhamento da decoração: cor do carpete, definições de tecido, cor, material, entre outros.

Essa característica de produto modular é refletida na sua estrutura de redes de fornecimento. Um dos itens que levou a esse projeto de pesquisa foi investigar se havia uma tendência de diminuir a quantidade de fornecedores e parceiros nos projetos da empresa, devido aos números apontados em alguns estudos anteriores:

Nos anos de 1980, 500 firmas forneciam peças e componentes ao avião Brasília. Nos anos de 1990, eram 350 trabalhando na fabricação dos jatos regionais e, a partir dos anos 2000, já são menos do que 100 envolvidos na produção dos novos aviões da empresa (MIRANDA, 2007, p. 104).

Para responder a esse questionamento foi preciso entender a estratégia estabelecida pela empresa desde o seu programa EMB 120 (Brasília), em que a manufatura total era de responsabilidade da Embraer e a cadeia produtiva era verticalizada. Já no programa 145 essa característica de verticalização se rompe com as parcerias de risco e a subcontratação de processos. Mas é com a estratégia do programa 170 que a desverticalização atinge a maior presença na empresa, com a estratégia de contratação de pacotes tecnológicos completos (ver Figura 25).

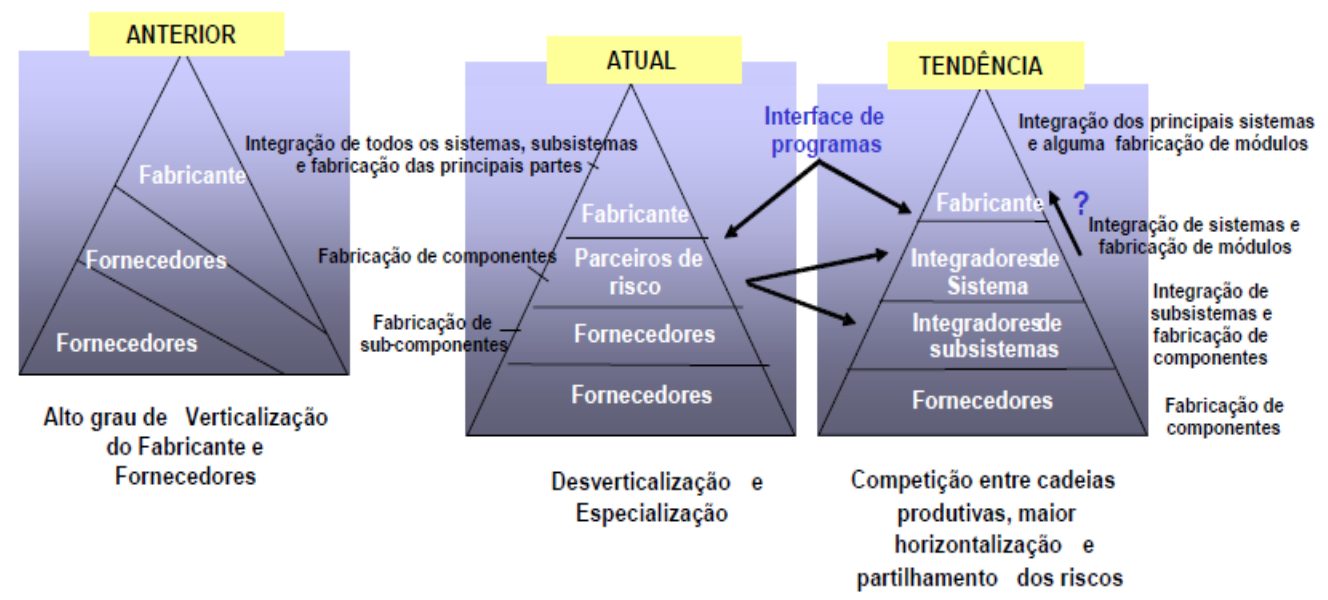

Figura 25 - Evolução da Cadeia produtiva no mundo Fonte: Oliveira (2005).

Pela Figura 25, a fase anterior caracteriza a empresa com o programa EMB 120. Na fase chamada atual encontra-se o projeto ERJ 145, em que a verticalização abre espaço para a desverticalização e especialização no desenvolvimento do projeto e na integração do produto. A fase chamada de tendência se refere ao programa 170, em que os parceiros de riscos passam a fazer a integração dos sistemas e a fornecer pacotes completos para a Embraer. 
Essa delegação de responsabilidades pela integração de subsistemas a um número maior de parceiros teve várias repercussões para os fornecedores. A Parker Hannifin e a Hamilton Sundstrand tiveram a oportunidade de subir um degrau na agregação de valor, adquirindo competências e se qualificando como fornecedores de soluções integradas nos subsistemas em que atuam, o que colaborou para que estabelecessem contratos posteriores com outras fabricantes, como foi o caso da Hamilton com o programa 787 da Boeing, explicam Montoro e Migon (2009).Porém, ao continuar os estudos com os programas seguintes ao programa 170/190, pode-se observar que não é possível afirmar que a delegação de responsabilidades é a tendência linear da empresa. Por exemplo, com o programa Phenom, a Embraer mostrou novamente uma tendência de verticalização. O programa tinha como premissa fazer tudo internamente (parte mecânica, estrutural, projeto e fabricação). Conforme entrevistas com a equipe de compras e a área de gestão da cadeia de suprimentos, houve algumas subcontratações por causa da capacidade da empresa, mas a regra geral era a otimização interna, isso porque a empresa tinha pressa para entrar no mercado (time to market) e não podia esperar pela capacitação e desenvolvimento de fornecedores. Não foi possível detectar, em todas as entrevistas realizadas, uma tendência linear com relação à estratégia de fornecimento. Não se pode afirmar que a empresa buscará, nos projetos futuros, a redução do número de fornecedores ou um aumento da externalização. O que se pode perceber foi uma postura pragmática, contingencial: o modelo de relação com fornecedores depende da situação de cada instante. Por exemplo, se a empresa tem capacidade ociosa, ela traz de volta o que externalizou e aproveita melhor a sua capacidade produtiva. Ter poucos relacionamentos diminui os custos administrativos de gestão; além disso, é uma característica atual da indústria da aviação o fabricante ser montador e interagir com o menor número de níveis possível, restringindo-se às primeiras camadas.

A seguir um resumo das entrevistas com as principais estratégias abordadas em cada programa sob o escopo da gestão de relacionamento com os fornecedores. 


\subsubsection{Programa 145}

Havia poucos fornecedores disponíveis. Para o caso da asa, por exemplo, os fornecedores cobravam um valor muito alto. A Embraer tinha o conhecimento e a tecnologia necessários para fazê-la, porém não tinha capital suficiente para esse gasto. Na época, um banco espanhol tinha capital disponível, e desse encontro de interesses surgiu a Gamesa, criada com o objetivo de suprir a asa para a Embraer. Os engenheiros da Embraer se instalaram na Gamesa para levar a tecnologia e o ferramental necessários. A Embraer sabia do risco de passar o domínio do desenvolvimento da asa, mas era a única forma de viabilizar o avião. Foram estabelecidas também parcerias relacionadas à estrutura, como o caso da ENAER para fuselagem traseira, Sonaca para fuselagem e peças, e C\&D para interiores.

Conforme as entrevistas o fundamento que guiou o modelo de relação com os fornecedores nesse programa foi a restrição de capital para investimento direto da Embraer, ou seja, a tecnologia que a Embraer detinha sem capital levou ao desenvolvimento de fornecedores não tradicionais.

\subsubsection{Programa 170}

A Embraer fez um benchmarking para conhecer o que havia de mais moderno em termos de gestão de desenvolvimento de novos produtos, visitando diversas empresas e discutindo com pesquisadores de universidades. A empresa montou o modelo de negócio de gestão do novo programa baseado na implementação de todas as ideias que julgou adequadas ao seu negócio. Um dos diferenciais ao lançar o Business Plan (BP) foi a não exigência de especificações, que era o que a maior parte dos fabricantes na época fazia. Pelo contrário, a Embraer criou o High Level Requirement, como já exposto anteriormente. Era uma forma de forçar os fornecedores a se integrarem mais entre si e com a empresa, conforme entrevista com a área de planejamento estratégico. Foram elaboradas as fases de definição do produto, cuja Joint-Definition-Phase (JDP) exigia a presença 
física de todos os fornecedores dos principais sistemas. Em suma, foi um programa cuja principal característica foi uma gestão de compartilhamento de risco e parceria, conforme entrevista com a equipe de compras. O parceiro assumia o risco do investimento do desenvolvimento, ou seja, todos os gastos referentes ao desenvolvimento do sistema que ele forneceria, e se o programa não desse certo, arcava com esse prejuízo. Entretanto, se o programa desse certo, ganhava a exclusividade do fornecimento. O cenário econômico era propício, pois no mercado havia pouquíssimos projetos novos de avião. Portanto a oferta de fornecedores disponíveis "brigando" para entrar no programa era muito grande.

Essa disponibilidade deu a oportunidade para a Embraer estabelecer de forma detalhada algumas "regras e padrões", o que facilitou a gestão dos fornecedores, assim como a integração dos sistemas. Por exemplo, a empresa exigiu que todos trabalhassem com a mesma versão do software (Catia), que todos os fornecedores viessem para o Brasil e aqui permanecessem por 8 meses, e gerenciou de perto o desempenho de cada um. Essa forma rígida de a Embraer padronizar, definir a interface entre fornecedores e garantir a integração pessoal e documental evitou problemas de integração. Tais problemas foram enfrentados posteriormente pela Airbus no A380 e pela Boeing no programa $787 \mathrm{com}$ a integração técnica. Apesar de toda essa rigidez, os fornecedores tinham grande interesse em entrar para o programa, pois era a primeira vez que uma montadora ensinaria como fazer a integração. A Embraer sabia do risco de passar parte do conhecimento que tinha para os fornecedores, mas era o único meio de viabilizar o modelo, conforme entrevista com a área de planejamento estratégico.

O grande diferencial da Embraer nesse modelo foi a sua flexibilidade de agir a tempo para que o programa se efetivasse, seja retomando internamente a fabricação de algum item, seja ensinando o fornecedor a fazer de outra forma. Com relação à engenharia financeira, o que se pode dizer é que os fornecedores tinham dois tipos de custos: o recorrente, relacionado com a produção em série, e o não recorrente, relacionado com o projeto do novo produto. São os gastos iniciais que não se repetem ao longo da série, por exemplo, os gastos com a concepção, o desenho, o ferramental, o treinamento e consultoria específicos. Tal custo, por sua vez, precisava ser amortizado na série: daí a negociação em amortizar tais custos nas vendas das primeiras peças para a Embraer. As partes negociavam baseadas na estimativa de vendas do programa, em quantas peças e no valor do acréscimo no 
preço de forma a amortizar o não recorrente. Dessa forma, as peças começavam com um preço mais caro, mas ao longo do programa esse preço diminuía e isso era importante, pois permitia um aumento na margem de lucro e uma flexibilidade na margem para baixar o preço, caso houvesse necessidade de responder a alguma expectativa do mercado. Portanto, a amortização na série era negociável.

Em suma, conforme as entrevistas, esse programa apresentou um fornecimento mais integrado, com desenvolvimento e responsabilização dos fornecedores envolvidos, num cenário de baixa na indústria aeronáutica, o que aumentou o poder de barganha da Embraer. Para viabilizar tal tipo de relação, foi fundamental a competência para especificar cada parte e para integrá-las posteriormente.

\subsubsection{Programa Phenom}

Esse programa teve dois grandes drivers: cadência de produção alta e custo baixo. Era um programa de categoria nova para a Embraer e os fornecedores estavam mais apreensivos com relação à viabilidade e consolidação da marca Embraer no mundo da aviação executiva. Com risco mais elevado, os fornecedores procuravam cobrar mais, e o custo da terceirização acabou ficando maior que o da fabricação interna. Por isso a Embraer, para esse programa, adotou um modelo de integração vertical: ela se volta para produção interna de componentes de estrutura. A empresa mantém o modelo de parceria, como no caso da empresa Pratt\&Whitney, fornecedor de motor, e de outros fornecedores de tecnologias, como componentes e sistemas, nos quais a empresa não tem competência.

Nesse programa, portanto, o que se pode constatar é que o modelo foi definido de forma clássica, através de análise de custo. 


\subsubsection{Programa Jatos Médios (Legacy 450/500)}

Nesse programa, o cenário econômico e empresarial é diferente do programa anterior. Com o sucesso do programa Phenom, os fornecedores passaram a ter grande interesse em entrar no programa. As características do modelo de gestão do programa 170 , portanto, retornam, com todas as três fases do projeto: definições iniciais, definições conjuntas e a certificação e projeto detalhado. É incluída a exigência de integração de sistemas e a presença de parceiros, principalmente porque, com o programa anterior, os fornecedores mundiais reconheceram a Embraer como um grande player da aviação executiva, concorrendo em igualdade com Cessna e Gulfstream. Os grandes drivers desse programa foram: produto diferenciado, produto superior no mercado e preço inferior. Trata-se de um programa com mais respaldo, com mais fornecedores querendo entrar (ainda mais porque o cenário mundial no qual estavam inseridos não apresentava muitos lançamentos de produto) e, como resultado, mais margem para negociação.

A relação com o fornecedor ainda está sendo definida devido à fase inicial em que o programa se encontra, diferentemente dos programas anteriores.

\subsubsection{Programa KC-390}

Trata-se de um programa com características diferentes por ser da área de defesa; no entanto, assim como o programa 170, também tem parceiros, que precisam ser aprovados pelo cliente, por questões políticas. Nos programas militares quem encomenda é quem paga pelo desenvolvimento, pois como é um programa por encomenda personalizado para um único cliente, não se espera grande sucesso comercial com outros clientes. Daí a exigência do pagamento pelo cliente para as fases do desenvolvimento. De qualquer forma, tal tipo de programa pode ter sucesso comercial, como no caso do Tucano, mas isso não é premissa a priori para seu desenvolvimento. 
Em resumo, programas especiais de tipo militar com condições próprias, negociadas com o cliente (Força Aérea que banca o desenvolvimento e as compras, ao menos as iniciais), e o modelo de relação com fornecedores dependem dessas condições, conforme entrevistas.

\subsection{A evolução dos programas sob o aspecto das implicações apontadas nas questões de pesquisa.}

As seções anteriores descreveram os projetos de forma isolada. Nesta seção o que se pretende é analisar a evolução dos programas sob os aspectos das questões da pesquisa. $O$ primeiro deles se refere à estratégia na relação com os fornecedores, incluindo a decisão de produzir ou comprar, e às parcerias de risco.

Nesse escopo o que se pode dizer é que, ao longo dos programas, a empresa mostrou sua preocupação com a integração (sua core competence) principalmente no programa 170 , com a gestão de sua cadeia de suprimentos, e com a análise de fazer versus comprar. Não se pode afirmar que houve uma queda na quantidade de fornecedores e parceiros, e nem afirmar que existe uma tendência interna na empresa em relação ao número de fornecedores a serem empregados nos projetos. No entanto, houve uma tratativa diferencial no relacionamento dos parceiros e fornecedores ao longo dos programas à medida que a empresa foi adquirindo um maior conhecimento tecnológico e diminuindo sua dependência junto aos fornecedores.

Outro aspecto da questão de pesquisa se refere à evolução dos projetos na forma como a fabricante coordena as atividades de desenvolvimento do produto com os diversos fornecedores. O que se pode observar nos resultados é que o programa 170 foi um marco para a empresa sob esse aspecto de coordenação de atividades para os projetos novos, com a implantação da gestão do Desenvolvimento Integrado do Produto (DIP) e suas três fases (definição inicial, definição conjunta e detalhamento do projeto). Tal gestão serviu de exemplo para os demais programas.

Com relação aos critérios utilizados na seleção dos fornecedores o que se 
pode observar nas entrevistas é que tais critérios variaram em cada programa. Por exemplo, no programa 145, como havia uma grande necessidade de investimento, os critérios na seleção dos fornecedores foram menos rigorosos. Ao longo dos outros programas os critérios passaram a ser mais cuidadosos sob o aspecto técnico. Por exemplo, exigências de conhecimento e qualidade se fortaleceram nas RFPs (Request for Proposal) utilizadas no processo de seleção. Sob esse aspecto é importante ressaltar a importância do fornecedor e das contribuições dos parceiros para os programas da Embraer: o que se observou é que o parceiro de risco da Embraer desenvolve e produz componentes e subsistemas significativos da aeronave, incluindo motores, componentes hidráulicos, aviônicos, asas, cauda, interior, partes da fuselagem etc. Determinados contratos firmados entre a Embraer e esses parceiros de risco caracterizavam-se por parcerias de longo prazo. $O$ longo prazo pode ser aqui entendido como o prazo que envolve o ciclo de produção e o ciclo de vida útil do avião, sendo que o ciclo de produção pode variar de quatro a dez anos e o de vida útil do avião pode variar de 20 a 30 anos, segundo entrevistas com a área de planejamento estratégico. Uma vez selecionados os parceiros de risco e iniciado o programa de desenvolvimento e produção das aeronaves, tornavase muito difícil substituí-los; em alguns casos, como os de motores, a aeronave era projetada especialmente para acomodar um determinado componente, o qual não poderia ser substituído por outro fornecedor sem incorrer em atrasos e despesas adicionais.

Essa dependência foi verificada no estudo, pois todos os programas apresentavam essa característica que torna a Embraer suscetível ao desempenho, qualidade e condições financeiras de seus parceiros de risco.

A Embraer possui acordo com seus parceiros de risco para participar de atividades de pesquisa e desenvolvimento. Alguns contratos com esses parceiros requerem contribuição financeira, por parte deles, para a Embraer, como forma de compensação de suas atividades de pesquisa e desenvolvimento.

Durante as pesquisas em campo o que se relatou é que essas contribuições estão atreladas ao cumprimento pela Embraer de algumas etapas e eventos importantes do desenvolvimento, incluindo: certificação da aeronave, primeira entrega e número mínimo de aeronaves entregues.

A Embraer registra essas contribuições financeiras quando recebidas como passivo não circulante, as quais não são exigidas caso os objetivos contratuais 
sejam alcançados. À medida que essas etapas e eventos são alcançados e, portanto, não mais são passíveis de devolução, esses valores são abatidos dos gastos de desenvolvimento das aeronaves.

Quanto ao aspecto das estratégias de fornecimento modular que a empresa teve em cada caso, o que se pode observar é que os aspectos da modularidade estão presentes em todos os programas, uma vez que seus principais sistemas se comportam como sistemas modulares: sistema de ar condicionado, sistema de propulsão, sistema de trem de pouso etc. Sobre o aspecto do comportamento na forma organizacional em modular ou vertical, o que se pode observar é que o fator central para explicar o escopo parcialmente vertical da Embraer adotado no programa Phenom estava diretamente ligado ao processo de acumulação de capacitações, que foi conseguido ao longo do tempo através da aprendizagem em relação às tecnologias específicas, produtivas e de domínio do mercado adquiridas ao longo dos programas 145 e 170/190. O quadro 19 abaixo mostra a evolução dos modelos de relação com fornecedores e as contingências que sustentaram cada programa:

\begin{tabular}{|c|c|}
\hline Programa & Contingências que sustentaram cada modelo \\
\hline \multirow{4}{*}{ Programa 145} & Poucos fornecedores disponíveis \\
\hline & Modelo guiado pela restrição de capital \\
\hline & Domínio tecnológico pela Embraer \\
\hline & $\begin{array}{l}\text { Falta de capital levando ao desenvolvimento de } \\
\text { fornecedores menos tradicionais }\end{array}$ \\
\hline \multirow{4}{*}{ Programa 170} & Fornecimento mais integrado \\
\hline & Programa com alto investimento, avião de maior porte \\
\hline & $\begin{array}{l}\text { Desenvolvimento e maior responsabilização por parte dos } \\
\text { fornecedores }\end{array}$ \\
\hline & $\begin{array}{l}\text { Cenário em baixa na indústria aeronáutica, muitos } \\
\text { fornecedores disponíveis, aumento do poder de negociação } \\
\text { da Embraer }\end{array}$ \\
\hline \multirow{3}{*}{ Phenom } & $\begin{array}{l}\text { Maior ênfase na análise de custo, devido à margem } \\
\text { reduzida do programa }\end{array}$ \\
\hline & Definições baseadas em cadência de produção alta \\
\hline & $\begin{array}{l}\text { Preço alto cobrado pelos fornecedores, o que levou a uma } \\
\text { maior produção das partes internamente pela empresa }\end{array}$ \\
\hline
\end{tabular}




\begin{tabular}{|c|l|}
\hline Programa & Contingências que sustentaram cada modelo \\
\hline \multirow{4}{*}{$\begin{array}{c}\text { Programas Jatos } \\
\text { Médios (450/500) }\end{array}$} & $\begin{array}{l}\text { Embraer reconhecida pela base de fornecedores como um } \\
\text { grande "player" }\end{array}$ \\
\cline { 2 - 2 } & Poder de negociação da Embraer elevado \\
\cline { 2 - 2 } & Fornecimento integrado \\
\hline \multirow{4}{*}{ KC-390 } & Programa especial do tipo militar \\
\cline { 2 - 2 } & Condições próprias negociadas pelo cliente \\
\cline { 2 - 2 } & Fornecedores acordados entre as partes: cliente e Embraer \\
\hline
\end{tabular}

Quadro 19 - Evolução dos modelos

Fonte: Elaborado pela autora

Em suma, caso se adote uma comparação dos programas, o que se pode concluir é que eles representaram uma curva de aprendizagem para a empresa em estudo. Inicialmente, no programa 145, a maior preocupação estava no escopo financeiro, mas ao longo dos programas as estratégias e as competências tecnológicas foram sendo acumuladas e refletidas na forma de lidar com seus fornecedores e parceiros. 


\section{CONCLUSÕES}

O objetivo do trabalho foi investigar os fatores que levaram à adoção de estratégias de parcerias de risco em um caso e ao seu abrandamento em outro, levantar a evolução dos projetos quanto à forma de coordenar as atividades de desenvolvimento do produto com relação aos fornecedores, e investigar os requisitos de seleção dos fornecedores em cada linha de produtos.

Para auxiliar o trabalho foi tomado como referência bibliográfica 0 desenvolvimento do produto vinculado a tecnologia, inovação e arquitetura modular, forma organizacional vertical e em redes modulares, além do enfoque na estratégia de gestão da cadeia de fornecimento com alianças estratégicas e critérios de seleção.

Com relação à primeira pergunta sobre a adoção de parcerias em um caso e o seu abrandamento em outro, o que se pode concluir é que a estratégia da Embraer em relação aos seus fornecedores e parceiros está sustentada em três pilares: produto com caráter modular (característico da indústria aeronáutica), complexidade tecnológica dos produtos e engenharia financeira vinculada no processo de parceria.

Sobre o enfoque da evolução dos projetos com relação aos fornecedores e os critérios utilizados na sua escolha, o que se pode identificar é que, no início, a Embraer era considerada uma empresa pouco conhecida no mercado e por isso precisava ser muito flexível e pouco exigente no processo de seleção para que os fornecedores entrassem no projeto. Hoje, a empresa não precisa ceder tanto nas negociações com seus fornecedores (dar exclusividade de fornecimento, ajudar o fornecedor a se capacitar, desenvolver ferramental, ajudar no desenvolvimento dos componentes etc), pois ela já conquistou sua posição no mercado, sendo uma empresa de referência para a base de fornecedores do setor de aviação. O sistema de parceria foi fundamental para o seu desenvolvimento. O parceiro assume riscos: o projeto pode dar certo ou não e esses riscos envolvem o não recorrente, como a engenharia, o projeto, o ferramental, o custo para fazer. Contudo, por outro lado, os parceiros adquirem o know-how do qual ganham a exclusividade do projeto. A definição de parceiro tem mais a ver com a engenharia do produto. O parceiro é um 
sócio e participa em campanhas de vendas. Já o fornecedor é regido por um contrato normal de compra e venda, por uma relação puramente comercial.

Quanto à questão sobre a quantidade de fornecedores, conclui-se que não se pode afirmar que exista uma regra a respeito disso dentro na empresa. No programa Phenom a tendência foi a verticalização e, por conseguinte, a redução da base de fornecimento, devido à necessidade de entrar logo no mercado e à falta de tempo de selecionar e desenvolver fornecedores (time to market). No programa Legacy 450/500 isso ocorreu devido à necessidade de dominar tecnologicamente material composto e os incentivos externos: optou-se pela fabricação interna da asa na filial em Portugal, na cidade de Évora. Apesar desses exemplos de fabricação interna, não se pode afirmar que a empresa tem como meta redução da sua base de fornecimento. Para cada programa uma série de fatores são considerados.

Com relação à complexidade do produto, essa é muito alta e haverá sempre a necessidade de a montadora coordenar a integração. Além disso, a confiabilidade exigida, assim como os critérios para certificação, são muito rigorosos. Nesse sentido, o modelo de dupla hélice apresentado por Fine (2000) se assemelha ao da situação estudada. Há momentos em que as forças empurram a empresa para uma estrutura mais vertical e outros para uma estrutura mais modular. Se a análise de custo chegar ao limite, ou seja, se o preço a ser pago para a fabricação interna for o mesmo a ser pago ao fornecedor, a escolha será a decisão de comprar, isso porque a fabricação interna acaba gerando custos indiretos que a montadora teria que carregar. No caso da Embraer, não se pode fazer uma afirmação a respeito de uma tendência interna. Cada programa tem certa quantidade de variantes para decisões, o que leva a características de uma análise multidimensional.

Quanto à forma de se organizar (modular versus vertical), o que se pode observar é que no programa EMB-120 e no programa Phenom ela apresentou mais características de verticalização, mas tal comportamento na empresa é contingencial. Também é contingencial a parceria de risco com seus fornecedores, sua existência ou não, bem como a quantidade de parceiros a serem empregados.

Assim, o que se pode afirmar é que a racionalidade do modelo de relação com fornecedores em cada programa depende de um conjunto de contingências:

a) Do poder de mercado da Embraer, que no início teve problemas para efetuar contratos com parceiros, pois, dada a incipiência de sua marca e tradição no mercado, o que implicava em maiores incertezas relativas ao 
futuro, a empresa precisou submeter-se a condições não tão vantajosas.

b) De mercado, que, se aquecido, fortalece os fornecedores; caso contrário fortalece a Embraer.

c) Financeiras, pois, conforme a capacidade de investimento ou de alavancagem financeira da empresa, ela formata a relação com fornecedores de forma que um conjunto deles participe do negócio assumindo riscos e investindo no projeto, no que chamamos de parceria de risco.

d) De capacidade produtiva, pois a Embraer pode externalizar para não ter de investir em ampliação de sua capacidade.

e) Do próprio cliente, como no caso de projetos militares, que têm formatação e condições de viabilidade específicas, negociadas diretamente com o cliente que demanda o projeto, ainda que o contrato possibilite vendas a outras forças aéreas.

Em linhas gerais não há nenhuma tendência predefinida da empresa em se voltar para a verticalização e fabricação interna, nem diminuir a quantidade de parceiros/fornecedores. $O$ que se pode afirmar é que a cada lançamento vários drivers serão perseguidos, e o momento econômico terá grande influência na decisão da empresa. A empresa é regida por uma relação funcional e variável entre as condições ambientais (socioeconômicas) e as técnicas administrativas apropriadas para alcançar de forma eficaz os objetivos de sucesso de um novo projeto. 


\section{SUGESTÕES DE TRABALHOS FUTUROS}

Este trabalho foi desenvolvido sob a ótica da montadora. Ainda que tenham sido feitas sondagens com pessoal de fornecedores, estes não são o objeto. Nesse sentido, uma oportunidade seria a realização de pesquisa semelhante sob a ótica dos fornecedores. O quadro conceitual abordado poderia ser aplicado para reconhecer nos fornecedores da indústria aeronáutica as competências investigadas, como a organização da rede modular, com suas vantagens e desvantagens, e os ganhos de parcerias sob o ponto de vista do fornecedor. A realização de levantamento do tipo survey para aplicar os conceitos estudados no nível dos fornecedores de $1^{\circ}$ e $2^{\circ}$ níveis, de modo a comparar os resultados entre eles, poderia levar a uma investigação mais rica e completa. 


\section{REFERÊNCIAS BIBLIOGRÁFICAS}

ANAC, Agência Nacional de Aviação Civil. Total de Aeronaves Registradas por Tipo de Aeronave, 2009. Disponível em: <www.anac.gov.br>. Acesso em: 30 dez. 2009.

AECMA, European Association of Aerospace Industries. Industrial and structural issues, 2004. Disponível em: <www.aecma.com>. Acesso em: 28 fev. 2009.

ALVES FILHO, A. G. et al. Pressupostos do Gerenciamento da Cadeia de Suprimentos: evidências de estudos sobre a indústria automobilística. Gestão \& Produção, São Carlos, vol. 11, n. 3, set./dez., 2004, p. 275-288.

BALDWIN, C. Y.; CLARK, K. B. Managing in the ages of modularity. Harvard Business Review, vol. 75, n. 5, Sep/Oct, 1997. p. 84-93.

BANDEIRANTE 40 ANOS. Informativo EMBRAER para o Brasil e exterior. Embraer, ed. especial, ano 39, out., 2008. Disponível em: <http://www.embraer.com.br/ institucional/download/Revista_Arquivo_PDF/Revista_Bandeirante_Especial_Outubr o_2008.pdf >. Acesso em: 25 out. 2008.

BANDEIRANTE. Informativo EMBRAER para o Brasil e exterior. Embraer, ano 40, n. 735, agosto 2009.

BARBOSA, M. Boeing e Airbus copiam Embraer para reduzir custos. Jornal o Estado de São Paulo, Economia \& Negócios, 23 abr. 2008.

BASTOS, C. E. Atributos de parceria de sucesso em cadeias de suprimentos: um estudo de caso na relação fabricante - fornecedores na indústria aeronáutica. Dissertação (Mestrado em Economia). São Paulo: FEA, USP, 2006.

BERNARDES, R. Embraer: The Link between State and Market. São Paulo: Hucitec/ FAPESP, 2000.

BERNARDES, R.; PINHO, M. Aglomeração e aprendizado na rede de fornecedores locais da Embraer. Rede de Pesquisa em Sistemas Produtivos e Inovativos Locais. Rio de Janeiro: Universidade Federal do Rio de Janeiro, 2002. 
BRUSONI, S. The limits of specialization: problem solving and coordination in modular networks. Organization Studies, v. 26, n. 12, 2005. p.1885-1907.

CAMUFFO, A. Rolling out a world car: globalization, externalization and modularity in the auto industry. Department of Business Economics and Management Ca Foscari University of Vehicle, Italy, 2000. Disponível em: <http://www.imvp.mit.edu/ papers/0001/camuffo1.pdf>. Acesso em: 15 jan. 2009.

CASSIOLATO, J. E.; BERNARDES, R.; LASTRES, H. Transfer of Technology for Successful Integration into the Global Economy: A case study of Embraer in Brazil. UNCTAD/ITE/IPC/Misc.20, United Nations, New York and Geneva, 2002.

CHANDLER, $A$. The visible hand: the managerial revolution in American Business.Cambringe, MA: Belknap. Harvard University Press, 1997. Apud STURGEON, T. Modular production networks: a new American model of industrial organization. Industrial and Corporate Change, v. 11, n. 3, 2002. p. 451-496.

CHOY, K. L.; LEE, W. B. A. Generic Supplier Management Tool for Outsourcing Manufacturing. Supply chain management an international journal, vol. 8, n. 2, Apr. 2003, p. 140-154.

CLARK, K. B.; FUJIMOTO, T. Product Development Performance, Harvard Business School Press, Boston, MA. 1991

COLLINS, R.; BECHLER, K.; PIRES, S. Externalization in the automotive industry: from Just-In-Time to modular consortia. European Management Journal, v. 15, n. 5, 1997. p. 498-508.

CORRÊA, H. L.; CORRÊA, C. A. Redes de operação na cadeia de valor.

Administração da Produção e operações: manufatura e serviços: uma abordagem estratégica. São Paulo: Atlas, 2009.

COUGHLAN, P.; COGHLAN, D. Action research for operations management. International Journal of Operations \& Management, v. 22, n. 2, 2002.

DIAS, A. V. C. Produto mundial, engenharia brasileira: integração de subsidiárias no desenvolvimento de produtos globais no setor automotivo. 303p. Tese (Doutorado em Engenharia). Escola Politécnica, Universidade de São Paulo, São Paulo, 2003.

DIAS, A. V. C.; SALERNO, M. S. Condomínios industriais: novas fábricas, novos arranjos produtivos e novas discussões na indústria automobilística brasileira. In: XIX Encontro Nacional de Engenharia de Produção, 1999, Rio de Janeiro. XIX Encontro Nacional de Engenharia de Produção, 1999. 
DUSSAUGE, P.; GARRETTE, B. Determinants of success in international strategic alliances: evidence from the global aerospace industry. Journal of International Business Studies, v. 26, 1995. p. 505-530.

. Anticipating the evolutions and outcomes of strategic alliances between rival firms (the construction, forms, and consequences of industry networks).

International Studies of Management and Organization, v. 27, n. 4, 1997. p. 104116.

EISENHARDT, K. M. Building Theories from Case Study Research. Academy of Management. The Academy of Management Review, v. 14, n. 4, 1989. p. 532-550.

EMBRAER. Embraer em números. Embraer, Promocional, 2010a. Disponível em: $<$ http:Ilwww.embraer.com.br/portugues/content/imprensa/embraer_numeros.asp>. Acesso em: 02 mai. 2010.

EMBRAER. Documentos internos de engenharia. São José dos Campos, Engineering Embraer Day, 2009a.

EMBRAER. Tour Virtual. São José dos Campos: Embraer, 2009b. Disponível em: <http://www.embraer.com.br/portugues/content/home/>. Acesso em: 15 dez. 2009.

EMBRAER. Demonstrações Financeiras Padronizadas, 2009c. Disponível em: $<$ http:// ri.embraer.com.br /Central de Resultados/>. Acesso em: 02 mai. 2010.

EMBRAER. Embraer Day, Executive Aviation Overview, 19 mar. 2010b. Disponível em: <http:// ri.embraer.com.br>. Acesso em: 02 mai. 2010.

EMBRAER. Análise Comparativa dos jatos, 2010c. Disponível em: http://www.embraerexecutivejets.com.br/portugues/content/aircraft/phenom100_hom e.asp. Acesso em: 08 mai. 2010.

EMBRAER. Market Outlook 2009_2028, 6th Edition, 2010d. Disponível em: http://www.embraercommercialjets.com. Acesso em: 08 mai. 2010.

EMBRAER, Executive Jets. Embraer. Divulgação, 2008a. Disponível em: <http;|lwww.embraerexecutivejets.com.br>. Acesso em: 15 dez. 2008.

EMBRAER. Estimativas de demanda mundial abrangem os mercados de jatos comerciais e executivos. São José dos Campos, $9^{\circ}$ Encontro Anual de Analistas e Investidores, Embraer Day, 6 e 7 nov. 2008b. 
FARIA, P. O.; VANALLE, R. M. Critérios para a Seleção de Fornecedores: Uma Análise das Práticas de Grandes Empresas Industriais do Estado do Espírito Santo.

Fortaleza, XXVI ENEGEP, 9 a 11 out. 2006.

FINE, C. H. Clockspeed-based strategies for supply chain design. Production and Operations Management, v. 9, n. 3, 2000. p. 213-221.

FLEURY, A. C. C; FLEURY, M. T. L. Estratégias Competitivas e Competências Essenciais: perspectivas para a internacionalização da indústria no Brasil. Rev. Gestão e Produção, vol. 10, n. 2, ago., 2003, p. 129-144.

FREDRIKSSON, P. Modular assembly in the car industry - an analysis of organizational forms influence on performance. European Journal of Purchasing \& Supply Management, v. 8, 2002. p. 221-233.

GAMA. Statistical Data \& Industrial Outlook. General Aviation Manufacturers Association. Washington, DC, 2010. Disponível em: <http:|lwww.gama.aero>. Acesso em: 02 mai. 2010.

GARAI, G. Leveraging the rewards of strategic alliances. Journal of Business Strategy. v. 20, n. 2, Mar-Apr., 1999, p. 40-41

GIOSA, L. A. Terceirização: Uma abordagem estratégica. 5 ed. São Paulo: Pioneira, 1999.

GIUNTA, A. Supplier relations in commercial aircraft industry: the case of Alenia in southern Italy. In: INTERNATIONAL COUNCIL FOR SMAL BUSINESS. Naples Conference Procedings. Nápoles, 1999.

GRAZIADIO, T. Estudo comparativo entre fornecedores de componentes automotivos de plantas convencionais e modulares. 185p. Tese (Doutorado em Engenharia). São Paulo: Universidade de São Paulo, 2004.

GUTWALD, P.M. Strategic outsourcing and technology supply chains. Massachusetts: Massachusetts Institute of Technology,1995. Master's thesis (Management). Apud DI SERIO, L. C.; SAMPAIO, M. Projeto da Cadeia de Suprimentos: uma visão dinâmica da decisão fazer versus comprar. RAE, Seção: Administração da Produção e Sistemas de Informação, v. 41, n. 1, 2001.

HAGEDOORN, J.; NARULA, R. Choosing organizational modes of strategic technology partnering: international and sectoral differences. Journal of International Business Studies, 1996. p. 265-284. 
HAMEL, G.; PRAHALAD, C. K. Competing for the future. Boston: Harvard Business School Press, 1994.

HELMS, M. M.; DIBRELL, C.; WRIGHT, P. Competitive Strategies and Business Performance: Evidence from the Adhesives and Sealants Industry. Management Decision, vol. 35, 1997, p. 689-703.

HENDERSON, R. M.; CLARK, K. B. Architectural innovation: The reconfiguration of existing product technologies and the failure of established firms. Administrative Science Quartely, v. 35, n. 1, p. 9 (22 pages),1990. Apud BALDWIN, C. Y.; CLARK, K. B. Managing in the ages of modularity. Harvard Business Review, vol. 75, n.5, Sep-Oct, 1997. p. 84-93.

HOEK, R. I. V.; WEKEN, H. M. The impact of modular production on the dynamics of supply chains. International Journal of Logistics Management, v. 9, n. 2, 1998. p. 33-50.

HONG, Y.; PEARSON, J. N.; CARR, A. S. A typology of coordination strategy in multi-organizational product development. International Journal of Operations \& Production Management, v. 29, n. 10, 2009. p. 1000-1024.

HUMPHRIES, A. S.; WILDING, R. Partnership in UK defense procurement. International Journal of Logistics Management, v. 12, n. 1, 2001. p. 83.

JUNIOR, A. B. Alianças Estratégicas e Inovação de Valor. Estudo de caso dos jatos regionais 170/190 da Embraer. [Mestrado em Administração]. São Paulo: Pontifícia Universidade Católica, 2006.

JÜRGENS, U., Restructuring of Supplier Relations within the Automotive Industry. Working Group Knowledge, Production Systems and Work. Conference Documentation - Where is the limit to corporate responsibility? Trade relations and supply chain responsibility of multinational enterprises - Misereor and the Publications Department of the Church Development Service, Germanwatch, 2004.

KLOTZLE, M. C. Alianças estratégicas: conceito e teoria. Revista de Administração Contemporânea, v. 6, n. 1, jan./abr. 2002. p. 85-104.

LANGLOIS, R. N.; ROBERTSON, P. L. Innovation, networks, and vertical integration. Research Policy 24, 1995, p543-562. Apud MALERBA, F.; NELSON, R.; ORSENIGO, L.; WINTER, S. Vertical Integration and disintegration of computer firms: a history-friendly model of coevolution of the computer and semiconductor industries. Industrial and Corporate Change, v. 17, n. 2, 2008. p. 197-231. 
LANGLOIS, R. N. The Vanishing Hand: the Changing Dynamics of Industrial Capitalism. The University of Connecticut, 2001.

LIMA, José Carlos de Souza. Um estudo sobre reconfiguração da função de compras em empresas do setor automotivo. 172p. Tese (Doutorado) - Escola Politécnica da Universidade de São Paulo. Departamento de Engenharia de Produção. São Paulo: Universidade de São Paulo, 2004.

LIU, J.; DING, F. Y; LALL, V. Using Data Envelopment Analysis to Compare Suppliers for Supplier Selection and Performance Improvement. Supply Chain Management: An International Journal, vol. 5, n. 3, 1 Mar., 2000, p. 143-150.

LORANGE, P.; ROOS, J. Alianças Estratégicas: formação, implementação e evolução. São Paulo: Atlas,1996.

LUNG, Y. et al. Flexibility through modularity: experimentations with fractal production in Brazil and in Europe, in LUNG, Y.; CHANARON, J. J.; FUJIMOTO, I; RAFF, D (Eds.) Coping with Variety: Flexible Productive Systems for Product Variety in the Auto Industry, Ashgate Publishing, Aldershot, 1999, p. 224-257.

MACHADO, Marcelo A. Global Knowledge Networking for Innovation: A Case Study of Embraer. KMPRO Journal, v. 2, n. 1, spring, 2005.

MALERBA, F.; NELSON, R.; ORSENIGO, L.; WINTER, S. Vertical Integration and disintegration of computer firms: a history-friendly model of coevolution of the computer and semiconductor industries. Industrial and Corporate Change, v. 17, n. 2, 2008. p. 197-231.

MARTIN, M. V.; ISHII, K. Design for variety: developing standardized and modularized produt plataform architectures. Research in Enigneering Design, v. 13, 2002. p. 213-235.

MARTINS, R. Estratégia de compras na indústria brasileira de higiene pessoal e cosméticos: um estudo de casos. Dissertação (Mestrado). Rio de Janeiro: Instituto Coppead, UFRJ, 2005.

MARX, R.; ZILBOVICIUS, M.; SALERNO, M. S. The modular consortium in a new VW truck plant in Brazil: new forms of assembler and supplier relationship. Integrated Manufacturing Systems, v. 8, n. 5, 1997. p. 292-298.

MELLO, O. R. S. S. Possíveis impactos da introdução dos "jatos muito leves" na indústria do transporte aéreo. São José dos Campos: ITA, 2005. 
MENEZES, P. R. L. A Aviação Executiva: Estudo das utilizações Estratégicas de um Serviço. 143f. Dissertação [Mestre em Engenharia]. Porto Alegre: UFRGS, 2004.

MIGUEL, P. A. C. Estruturação do Processo de Desenvolvimento de Produtos e a Introdução de um Método de Suporte: Uma Intervenção por meio da Pesquisaação. Livre-docência. Universidade de São Paulo, São Paulo, 2006.

. Estudo de caso na engenharia de produção: estruturação e recomendações para sua condução. Rev. Produção, vol. 17, n. 1, jan./abr., 2007. p. 216-229.

MILGATE, M. Supply Chain Complexity and Delivery Performance: An International Exploratory Study. Supply Chain Management: An International Journal, vol.6, n. 3, 2001, p. 106-118.

MIN, H. International Supplier Selection: A Multi-attribute Utility Approach. International Journal of Physical Distribution \& Logistics Management, v. 24, n. 5, 1 May 1994. p. 24-33.

MIRANDA, I. M. O voo da Embraer: a competitividade brasileira na indústria de alta tecnologia. São Paulo: Papagaio, 2007.

MONCZKA, R. M.; HANDFIELD, R. B.; GIUNIPERO, LARRY, C.; PATTERSON, J. L. Purchasing and Supply Chain Management. Mason, OH, USA: South-Western Cengage Learning, 2009.

MONTORO, G. C. F.; MIGON, M. N. Cadeia produtiva aeronáutica brasileira: oportunidades e desafios. Rio de Janeiro: BNDES, 2009.

MOTWANI, J. et al. Supplier selection in developing countries: a model development. Integrated Manufacturing Systems, vol. 10, n. 3, Mar, 1999, p.154-162.

NIOSI, J.; ZHEGU, M. Aerospace clusters: local or global knowledge spillovers? Industry and Inovattion, v. 1, n. 12, Mar 2005. p.5.

OLIVEIRA, L. G. A cadeia de produção aeronáutica no Brasil: uma análise sobre os fornecedores da Embraer. Tese [doutorado]. Campinas: Universidade Estadual de Campinas, 2005.

PAVITT, K. Specialization and systems integration: where manufacture and services still meet. In: PRENCIPE, A., DAVIES, A.; HOBDAY, M. The business of systems integration. Oxford: OUP, 2003. 
PEREIRA, R.F.. Seleção e gestão da cadeia de fornecedores do setor aeronáutico: um estudo de caso. 110f. Mestrado [Engenharia de Produção]. São Paulo: Escola Politécnica da USP, 2002.

PHALL, R.; FARRUKH, C. J. P.; PROBERT, D. R. Technology roadmapping: A planning framework for evolution and revolution. Int. J. Technological Forecasting and Social Change, v. 71, 2004. p. 5-26.

PINTO, A. K.; XAVIER, J. A. N. Manutenção: função estratégica. 2 ed. Rio de Janeiro: Qualitymark, 2002.

PRAHALAD, C. K.; HAMEL, G. A . The Core Competence of the Corporation Harvard Business Review, vol. 68, n. 3, 1990, p. 37-42.

PRIETO, E. Implicações da estratégia modular no processo de capacitação e na transferência de atividades de desenvolvimento de produto entre os fornecedores de nível 1 e 2 da cadeia automotiva.103p. Dissertação (Mestrado) - Escola Politécnica da Universidade de São Paulo. Departamento de Engenharia de Produção. São Paulo, 2007.

PROBERT, D. R.; PHAAL, R.; FARRUCKH, C. J. P. Structuring a systematic approach to technology management: concepts and practice. International Association for Management of Technology (IAMOT) Conference, Lausanne, 22 March, 2000. Apud PHALL, R.; FARRUKH, C. J. P.; PROBERT, D. R. Technology roadmapping: A planning framework for evolution and revolution. Int. J. Technological Forecasting and Social Change, v. 71, 2004. p. 5-26.

ROZENFELD, H. et al. Gestão de Desenvolvimento de Produtos: uma referência para a melhoria do processo. São Paulo: Saraiva, 2006.

SALERNO, M. S. The characteristics and the role of modularity in the automotive business. Int. J. Automotive Technology and Management, v. 1, n. 1, 2001. p. $92-$ 107.

SALERNO, M. S.; CAMARGO, O. S.; LEMOS, M. B. Modularity ten years after: an evaluation of the Brazilian experience. Int. J. Manufacturing Technology and Management, v. 8, n. 4, 2008. p. 373-381.

SALERNO, M. S.; MARX, R.; ZILBOVICIUS, M.; DIAS, A. V. C. The importance of locally commanded design for the consolidation of local supply chain: the concept of design headquarters. Int. J. Manufacturing Technology and Management, v. 16, n. 4, 2009. p. 361-376. 
. Mudanças e persistências no padrão de relações entre montadoras e autopeças no Brasil. Revista de Administração, FEA-USP, v. 33, n. 3, p. 16-28, jul./set. 1998.

SANTOS, M. S. B. A. Evolução da frota brasileira de aeronaves da aviação geral. São José dos Campos: ITA, 2003.

SILVA, C. L. Competitividade e Estratégia empresarial: um estudo de caso da indústria automobilística brasileira na década de 1990. Rev. FAE, Curitiba, vol. 4, n. 1, jan./abr., 2001, p. 35-48.

SILVA, C. P. A terceirização responsável: modernidade e modismo. São Paulo: LTR, 1997.

SLACK, N.; JOHNSTON, R.; CHAMBERS, S. Administração da produção. São Paulo: Atlas, 2002.

STURGEON, T. Modular production networks: a new American model of industrial organization. Industrial and Corporate Change, v. 11, n. 3, 2002. p. 451-496.

TEECE, D. J. Competition, cooperation and innovation: organizational arrangements for regimes of rapid technological progress. Journal of Economic Behavior and Organization, v. 18, 1992. p. 1-25.

TIDD, J.; BESSANT, J.; PAVITT K. Managing Innovation: integrating technological, market and organizational change. 2 ed. England: Wiley, 2001.

$\mathrm{ULRICH}, \mathrm{K}$. The role of product architecture in the manufacturing firm. Research Policy, v. 24, 1995. p. 419-440.

VIEIRA, M. G. Comparação entre o método de análise hierárquica e um modelo decisório existente para a seleção de fornecedores de uma empresa aeronáutica. XXIV Encontro Nac. de Eng. de Produção. Florianópolis, 2004.

VOSS, C. et al. Case Research in Operations Management. International Journal of Operations and Production Management, vol. 22, n. 2, 2002, p. 195-219.

YIN, R. K. Estudo de Caso: Planejamento e Método. 2 ed. São Paulo: Bookman, 2001. 


\section{APÊNDICES}

\section{APÊNDICE A - Entrevistas - Primeira Parte}

\section{PRO}

Escola Politécnica da Universidade de São Paulo - Departamento de Engenharia de Produção

Área:

Cargo/Função:

Formação:

Tempo na empresa:

Objeto de Estudo: Analisar a estratégia na relação com os fornecedores, incluindo a decisão de make or buy, em empresa de alta tecnologia e produtos complexos. Investigar os fatores que levaram à adoção de estratégias de parcerias de risco em um caso e ao seu abrandamento em outro.

1) Onde começa o processo de decisão de make or buy?

2) Quais áreas são envolvidas no processo de um novo projeto?

3) Quem decide quantos fornecedores/parceiros haverá?

4) Qual a diferença de parceiro de risco, parceiro e fornecedor? Essa definição mudou ao longo dos programas?

5) A definição de parceria envolve o compartilhamento do projeto e investimento no fabricante?

6) Que evolução que ocorreu no processo de seleção dos fornecedores se o compararmos com os programas acima? 


\section{APÊNDICE B - Entrevistas - Segunda Parte}

PRO

Escola Politécnica da Universidade de São Paulo - Departamento de Engenharia de Produção

Área:

Cargo/Função:

Formação:

Tempo na empresa:

Objeto de Estudo: Analisar a estratégia na relação com os fornecedores, incluindo a decisão de make or buy, em empresa de alta tecnologia e produtos complexos. Investigar os fatores que levaram à adoção de estratégias de parcerias de risco em um caso e ao seu abrandamento em outro.

1) Como começa o processo de decisão de make or buy?

2) Quais áreas são envolvidas no processo de um novo projeto?

3) Como é a relação com parceiros e com fornecedores?

4) Como você define Parceiro e Fornecedor nos programas abaixo?

\begin{tabular}{|l|l|l|}
\hline \multicolumn{1}{|c|}{ Familia } & \multicolumn{1}{c|}{ Parceiro } & Fornecedor \\
\hline 145 & & \\
\hline 170 & & \\
\hline Phenom & & \\
\hline Legacy $450 / 500$ & & \\
\hline KC-390 & & \\
\hline
\end{tabular}

5) Qual a abrangência da parceria em termos de:

- tecnologia:

- desenvolvimento do produto:

- finanças (investimento):

6) Quais os principais fatores/critérios utilizados na escolha dos parceiros para:

- 145:

- 170: 
- Phenom:

- Legacy 450/500:

- KC-390:

7) Houve mudança na estratégia da relação de "Parceiro" para "Fornecedor" ao longo dos programas? Por quê?

8) Como é feito o processo para estipular a quantidade de parceiros/fornecedores que participarão de cada programa e o valor que cada um terá que investir na Embraer?

9) Como é feito o retorno desse investimento ao parceiro/fornecedor? Como o parceiro pode ser beneficiado com o after-marketing?

10)A estratégia de fornecimento por subconjuntos inicialmente planejados para o programa 170 ainda é mantida? Por quê? Ela é aplicável aos programas novos abaixo?

- Phenom:

- Legacy 450/500:

- KC-390:

11)Qual a tendência hoje para os novos produtos? Em relação ao processo de fornecimento, por exemplo, existe uma tendência na empresa para ter menos fornecedores e ter mais fabricação interna?

- Phenom:

- Legacy 450/500:

- KC-390: 


\section{ANEXO A - Fornecedores de Primeiro Nível do Programa ERJ 135/140/145}

\begin{tabular}{|c|c|c|}
\hline $\begin{array}{l}\text { Categoria e Fornecedores } \\
\text { (Distribuição \%) }\end{array}$ & Componentes & País \\
\hline \multicolumn{3}{|l|}{ Hardware Elétrico (4\%) } \\
\hline E.G. \& G. Rotron & $\begin{array}{l}\text { Compartimento e ventiladores de } \\
\text { refrigeração eletrônicos }\end{array}$ & Estados Unidos \\
\hline Matrix & Conectores & Estados Unidos \\
\hline Mechanical products & Circuito de freios & Estados Unidos \\
\hline Raychen & Fios e Cabos & Estados Unidos \\
\hline Vickers & Bombas hidráulicas & Estados Unidos \\
\hline Eaton-MSC & Teclas & Estados Unidos \\
\hline ECE & Fusíveis e pontos de contato & Estados Unidos \\
\hline ABG Semca & Equipamentos de pressurização & França \\
\hline Allied Signal & $\begin{array}{l}\text { GPWS/detector de erosão de vento, } \\
\text { partida pneumática, gravador de dados } \\
\text { de voo e de voz de cabine. }\end{array}$ & Estados Unidos \\
\hline \multicolumn{3}{|l|}{ Hardware Mecânico } \\
\hline B.F.Goodrich & Rodas e Freios & Estados Unidos \\
\hline Goodyear & Pneus & Estados Unidos \\
\hline EDE & Trem de pouso & Brasil \\
\hline Liebherr & $\begin{array}{l}\text { Trem de pouso auxiliar e controle de } \\
\text { alerta }\end{array}$ & Alemanha \\
\hline Mason & Controle Aerodinâmico de freio & Estados Unidos \\
\hline Aviac & Atuador do ajuste do pedal e válvulas & França \\
\hline Crane. Hydro Aire & Controle de Freios & Estados Unidos \\
\hline \multicolumn{3}{|l|}{ Matéria Prima $(2 \%)$} \\
\hline Alcoa & Alumínio Aeronáutico & Estados Unidos \\
\hline \multicolumn{3}{|l|}{ Equipamento $(60 \%)$} \\
\hline Allison & Motor AE 3007 & Estados Unidos \\
\hline Lord & Motor dianteiro & Estados Unidos \\
\hline Eros & Oxigênio & França \\
\hline Rosemount & Detector de gelo & Estados Unidos \\
\hline Sextant & Indicador de velocidade e altímetro & França \\
\hline Sicma & Assento dos pilotos & França \\
\hline Sierracin & Para-brisas e janela de mau tempo & Estados Unidos \\
\hline Struthers Dunn & Relé & Estados Unidos \\
\hline Systron Donner & Detector de fogo & Estados Unidos \\
\hline Technofan & Ventilador & França \\
\hline Vibro-Meeter & $\begin{array}{l}\text { Computador de Manutenção Central e } \\
\text { motor de acompanhamento de vibração }\end{array}$ & Suíça \\
\hline Parker Hannifin & $\begin{array}{l}\text { Sistemas hidráulicos, de combustível e } \\
\text { de comando de voo }\end{array}$ & Estados Unidos \\
\hline Eldec & Sensor de proximidade & Estados Unidos \\
\hline Grimes & Unidades de alarme, aviso e iluminação & Estados Unidos \\
\hline Hamilton Standard & Sistema pneumático de ar condicionado & Estados Unidos \\
\hline
\end{tabular}




\begin{tabular}{|l|l|l|}
\hline $\begin{array}{c}\text { Categoria e Fornecedores } \\
\text { (Distribuição \%) }\end{array}$ & \multicolumn{1}{|c|}{ Componentes } & \multicolumn{1}{c|}{ País } \\
\hline Honeywell & Aviônicos & Estados Unidos \\
\hline Jet Electronic & $\begin{array}{l}\text { Bateria de emergência e indicador de } \\
\text { altitude }\end{array}$ & Estados Unidos \\
\hline Lucas Aerospace & Gerador & Estados Unidos \\
\hline $\begin{array}{l}\text { Marathon Power } \\
\text { Technologies }\end{array}$ & Baterias & Estados Unidos \\
\hline Pacific Scientific & Extintor & Estados Unidos \\
\hline Avtech & Comunicadores com passageiros & Estados Unidos \\
\hline Estruturas Metálicas & $(34 \%)$ & \\
\hline Gamesa & Asas, naceles, junção de fuselagem & Espanha \\
\hline Enaer & Empenagem vertical e horizontal & Chile \\
\hline Sonaca & $\begin{array}{l}\text { Compartimento de bagagem e portas } \\
\text { principais, seção dianteira e pilones }\end{array}$ & Bélgica \\
\hline Sundstrand/Labinal & Unidade auxiliar de potência & Estados Unidos/França \\
\hline Norton & Radome & Estados Unidos \\
\hline & Fonte: Embraer apud Cassiolato et al. (2002). \\
\hline
\end{tabular}




\section{ANEXO B - Fornecedores de Primeiro Nível do Programa ERJ 170/190}

\begin{tabular}{|c|c|c|}
\hline $\begin{array}{l}\text { Categoria e Fornecedores } \\
\text { (Distribuição \%) }\end{array}$ & Componentes & País \\
\hline \multicolumn{3}{|l|}{ Hardware Elétrico (4\%) } \\
\hline BFGoodrich & Sonda (Smart probe) & Estados Unidos \\
\hline BFGoodrich & Stick shaker & Estados Unidos \\
\hline BFGoodrich & TAT & Estados Unidos \\
\hline BFGoodrich & Limpador de para-brisas & Estados Unidos \\
\hline Hamilton Sundstrand & Sistema Elétrico & Estados Unidos \\
\hline Raychem & Fios e Cabos & Estados Unidos \\
\hline Eaton & Push buttons & Estados Unidos \\
\hline \multicolumn{3}{|l|}{ Hardware Mecânico } \\
\hline Liebherr & Trem de pouso & Alemanha \\
\hline Barber Colman & Aquecedor de para-brisas & Estados Unidos \\
\hline Parker & Controles de voos & Estados Unidos \\
\hline Pacific Scientific & Sistema de proteção de incêndio & Estados Unidos \\
\hline GEAE - GE Aerospace & Motores & Estados Unidos \\
\hline Air Industries & Hardware Mecânico & Estados Unidos \\
\hline AHG & Hardware Mecânico & França \\
\hline Fairchild & Hardware Mecânico & Estados Unidos \\
\hline Pentacon & Hardware Mecânico & Estados Unidos \\
\hline Textron & Hardware Mecânico & Estados Unidos \\
\hline \multicolumn{3}{|l|}{ Equipamento (60\%) } \\
\hline Parker & Sistema de combustível & Estados Unidos \\
\hline Hamilton Sundstrand & Sistema de ar & Estados Unidos \\
\hline Chelton & Descarregador de estática & Reino Unido \\
\hline AVTECH & Sistema de endereço de passageiros & França \\
\hline Honeywell & Aviônicos & Estados Unidos \\
\hline Chelton & Antenas VHF & Reino Unido \\
\hline Sensor & Antenas VOR/ILS & Estados Unidos \\
\hline Allied Signal & EGPWS & Estados Unidos \\
\hline Allied Signal & SSCVR / FDR & Estados Unidos \\
\hline Air Precision & Relógio & França \\
\hline Parker Hydraulics & Sistemas hidráulicos & Estados Unidos \\
\hline Vibrometer & EVM & Suiça \\
\hline Hexcel & Material Composto & Estados Unidos \\
\hline Pilkington Aerospace & Janelas & Estados Unidos \\
\hline PPG Industries, Inc. & Transparências de para-brisas & Estados Unidos \\
\hline Honeywell (Grimes) & Iluminação externa e de cabine & Estados Unidos \\
\hline IDD & Painéis acrílicos iluminados & Estados Unidos \\
\hline \multicolumn{3}{|l|}{ Matéria Prima (2\%) } \\
\hline Alcoa Mill Products & Folhas e chapas de alumínio & Estados Unidos \\
\hline
\end{tabular}




\begin{tabular}{|c|c|c|}
\hline $\begin{array}{l}\text { Categoria e Fornecedores } \\
\text { (Distribuição \%) }\end{array}$ & Componentes & País \\
\hline Corus & Chapas de Alumínio \& CTS & Alemanha \\
\hline VSMPO & Folhas e Chapas de Titânio & Rússia \\
\hline Alexco & Perfis extrudados de Alumínio & Estados Unidos \\
\hline Pechiney Aviation & Perfis extrudados de Alumínio & França \\
\hline Alcoa Forged Products & Peças forjadas de Alumínio & Estados Unidos \\
\hline Otto Fuchs & Peças forjadas de Alumínio & Alemanha \\
\hline Neuvant & Peças forjadas de Alumínio & Estados Unidos \\
\hline \multicolumn{3}{|l|}{ Estrutura (34\%) } \\
\hline Kawasaki & Topo da asa & Japão \\
\hline Kawasaki & Borda de ataque fixa & Japão \\
\hline Kawasaki & Borda de arrasto fixa & Japão \\
\hline Kawasaki & Pilone & Japão \\
\hline Kawasaki & Superfícies de Controle & Japão \\
\hline Latecoere & Central de fuselagem I & França \\
\hline Latecoere & Central de fuselagem III & França \\
\hline Latecoere & Portas & França \\
\hline C\&D & Interior & Estados Unidos \\
\hline Sicma & Assentos de piloto e copiloto & França \\
\hline Gamesa & Fuselagem traseira & Espanha \\
\hline Gamesa & Empenagem Horizontal & Espanha \\
\hline Gamesa & Empenagem Vertical & Espanha \\
\hline Akaer & $\begin{array}{l}\text { CFII / projeto de carenagem de fuselagem da } \\
\text { asa }\end{array}$ & Brasil \\
\hline Kaiser & Regulador de pressão / autorregulador & Estados Unidos \\
\hline Sonaca & Central de fuselagem II & Bélgica \\
\hline Sonaca & Slats & Bélgica \\
\hline NMF & Protetor da asa & Estados Unidos \\
\hline Saint Gobain & Radome & Estados Unidos \\
\hline Hamilton Sundstrand & Unidade de potencia auxiliar/cone de cauda & Estados Unidos \\
\hline \multicolumn{3}{|l|}{$\begin{array}{l}\text { Ferramentas e Serviços de } \\
\text { Fabricação }\end{array}$} \\
\hline Dynamic Solutions & Projeto de ferramentas & Brasil \\
\hline Matrinor S.L. & Ferramentas de carenagem & Espanha \\
\hline (Several Companies) & Ferramentas de fabricação & Brasil \\
\hline
\end{tabular}

Fonte: Embraer apud Cassiolato et al. (2002). 


\section{ANEXO C - Empresas locais subcontratada e seus parceiros de riscos}

\begin{tabular}{|c|c|c|c|}
\hline Empresas & Região & Subcontratadas & Tipo de Atividade das subcontratadas \\
\hline \multirow[t]{3}{*}{ Aeroserv } & \multirow[t]{3}{*}{ SJC } & Embraer & Serviços estruturais e de montagem \\
\hline & & Gamesa & Serviços de configuração de avião \\
\hline & & Sonaca & Serviços de configuração de avião \\
\hline \multirow[t]{3}{*}{ Akros } & \multirow[t]{3}{*}{ SJC } & Embraer & Serviços de engenharia de projetos \\
\hline & & Latecoere & Serviços de engenharia de projetos \\
\hline & & Sonaca & Serviços de engenharia de projetos \\
\hline Aeromot & $\begin{array}{l}\text { Porto } \\
\text { Alegre }\end{array}$ & Cyclone & $\begin{array}{l}\text { Tecnologias complexas e montagem } \\
\text { estrutural em metálica e materiais compostos, } \\
\text { tratamento superficial e térmico }\end{array}$ \\
\hline \multirow{4}{*}{$\begin{array}{l}\text { Dynamics } \\
\text { Solutions } \\
\text { Engenharia }\end{array}$} & \multirow[t]{4}{*}{ Campinas } & Embraer & Ferramentas de engenharia \\
\hline & & Hamilton Sundstrand & Suporte técnico \\
\hline & & Latecoere & Serviços de engenharia \\
\hline & & Gamesa & Serviços de Engenharia e Suporte técnico \\
\hline \multirow{3}{*}{$\begin{array}{l}\text { Serco } \\
\text { Engenharia }\end{array}$} & \multirow[t]{3}{*}{ SJC } & Embraer & Serviços de Engenharia \\
\hline & & Latecoere & Serviços de Engenharia \\
\hline & & Sobraer & Serviços de Engenharia \\
\hline
\end{tabular}

Fonte: Bernardes (2000) 